\section{Том 15. № 4 2018}

Учредитель

Национальный исследовательский университет «Высшая школа экономики»

Главный редактор

B.A. Петровский (НИУ ВШЭ)

Редакционная коллегия

Дж. Берри (Университет Куинс, Канада)

Г.М. Бреслав (Балтийская международная академия, Латвия)

Я. Вальсинер (Ольборгский университет, Дания) Е.Л. Григоренко (МГУ им. М.В. Ломоносова и Центр ребенка Йельского университета, США) B.А. Ключарев (НИУ ВШЭ)

Д.А. Леонтьев (НИУ ВШЭ и МГУ им. М.В. Ломоносова)

B.A. Лефевр (Калифорнийский университет, CША)

М. Лини (Рочестерский университет, США)

Д.В. Люсин (НИУ ВШЭ и ИП РАН)

Е.Н. Осин (НИУ ВШЭ)

А.Н. Поддьяков (НИУ ВШЭ)

Д.В. Ушаков (зам. глав. ред.) (ИП РАН)

М.В. Фаликман (НИУ ВШЭ)

A.B. Хархурин (Американский университет Шарджи, ОАЭ)

ВД. Шадриков (зам. глав. ред.) (НИУ ВШЭ)

C.P. Яголковский (зам. глав. ред.) (НИУ ВШЭ)

\section{Экспертный совет}

К.А. Абульханова-Славская (НИУ ВШЭ и ИП РАН) Н.А. Алмаев (ИП РАН)

B.А. Барабанщиков (ИП РАН и МГППУ)

T.Ю. Базаров (НИУ ВШЭ и МГУ им. М.В. Ломоносова)

А.К. Болотова (НИУ ВШЭ)

А.Н. Гусев (МГУ им. М.В. Ломоносова)

А.Л. Журавлев (ИП РАН)

A.B. Карпов (Ярославский государственный университет им. П.Г. Демидова)

П. Лучисано (Римский университет Ла Сапиенща, Италия)

А. Лэнгле (НИУ ВШЭ)

А.Б. Орлов (НИУ ВШЭ)

В.Ф. Петренко (МГУ им. М.В. Ломоносова)

B.M. Розин (ИФ РАН)

И.Н. Семенов (НИУ ВШЭ)

E.A. Сергиенко (ИП РАН)

Е.Б. Старовойтенко (НИУ ВШЭ)

Т.Н. Уиакова (ИП РАН)

А.М. Черноризов (МГУ им. М.В. Ломоносова)

А.Г. Шмелев (МГУ им. М.В. Ломоносова)

П. Шмидт (НИУ ВШЭ и Гиссенский университет, Германия)

\section{ПСИХОЛОГИЯ Журнал Высшей школы экономики}

ISSN 1813-8918; e-ISSN: 2541-9226

«Психология. Журнал Высшей школы экономики» издается с 2004 г. Национальным исследовательским университетом «Высшая школа экономики» и поддерживается департаментом психологии НИУ ВШЭ. Миссия журнала - это

- повышение статуса психологии как фундаментальной и практико-ориентированной науки;

- формирование новых предметов и программ развития психологии как интердисциплинарной сферы исследований;

- интеграция основных достижений российской и мировой психологической мысли;

- формирование новых дискурсов и направлений исследований;

- предоставление площадки для обмена идеями, результатами исследований, а также дискуссий по основным проблемам современной психологии.

В журнале публикуются научные статьи по следующим основным темам:

- достижения и стратегии развития когнитивной, социальной и организационной психологии, психологии личности, персонологии, нейронаук;

- методология, история и теория психологии;

- методы и методики исследования в психологии;

- интердисциплинарные исследования;

- дискуссии по актуальным проблемам фундаментальных и прикладных исследований в области психологии и смежных наук.

Целевая аудитория журнала включает профессиональных психологов, работников образования, представителей органов государственного управления, бизнеса, экспертных сообществ, студентов, а также всех тех, кто интересуется проблемами и достижениями психологической науки.

Журнал выходит 1 раз в квартал и распространяется в России и за рубежом.

Выпускающий редактор Ю.В. Брисева

Редакторы О.В. Шапошникова, О.В. Петровская,

Д. Вонсбро. Корректура Н.С. Самбу

Переводы на английский К.А. Чистопольская,

Е.Н. Гаевская

Компьютерная верстка E.A. Валуевой

Адрес редакции:

101000, г. Москва, Армянский пер. 4, корп. 2.

E-mail: psychology.hse@gmail.com

Сайт: http://psy-journal.hse.ru/

Перепечатка материалов только по согласованию с редакцией.

(с) НИУ ВШЭ, 2018 г. 


\section{Том 15. № 4 2018}

\section{ПСИХОЛОГИЯ \\ Журнал Высшей школы экономики}

\section{СОДЕРЖАНИЕ}

\section{Специальная тема выпуска: \\ «Российский психолог»: архитекторы икол}

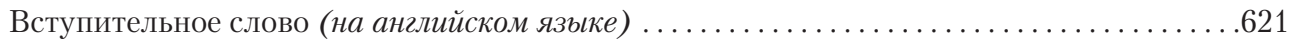

Вступительное слово . . . . . . . . . . . . . . . . . . . . . . . . . . . . . . . . 623

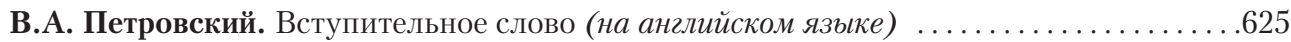

А.В. Петровский, В.А. Петровский. Категориальная система психологии. Опыт построения теории теорий психологии (на английском языке) . . . . . . . . . . . . . 626

Л.Я. Гозман, Д.А. Леонтьев. Вступительное слово (на английском языке) . . . . . . ...645

Г.М. Андреева, А.Н. Леонтьев. Методические проблемы исследования психологических аспектов социальных изменений (на английском языке) . . . . . . . . 646

А.Н. Поддьяков. Вступительное слово (на английском языке) . . . . . . . . . . . . . .655

А.Н. Поддьяков, Н.Н. Поддьяков. Интерактивные исследовательские объекты: от лабораторных экспериментов к массовым практикам XXI в.

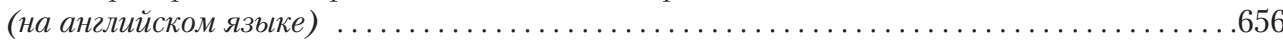

\section{Статьи}

М.А. Бульцева, Н.М. Лебедева. Роль индивидуальных ценностей и мотивации

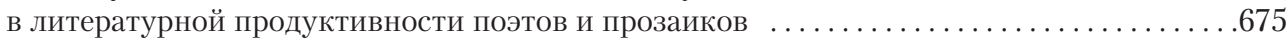
ОТОЗВАНА, 01.02.2019 А.В. Юревич. Психологическое состояние современного российского общества: новые тенденции

Е.Л. Григоренко, С. Торрес, Е.И. Лебедева, Е.А. Бондарь. Вмешательства при РАС с доказанной эффективностью: акцент на вмешательствах, основанных на прикладном анализе поведения (ПАП) (на английском языке) . . . . . . . . . . . . . . . . . . . . . . . . .711

Е.Б. Старовойтенко. Недиалогичное отношение к другому: регресс или оппозиция диалогичности (на английском языке) . . . . . . . . . . . . . . . . . . . . . . . . . . . . .

\section{Короткие сообщения}

Н.М. Лаптева, Е.А. Валуева, С.С. Белова. Прайминг-эффекты в задаче лексического решения на стимулах-словах с одинаковым буквенным составом 


\section{Vol. 15. No 4 2018}

Publisher

National Research University

Higher School of Economics

\section{Editor-in-Chief}

Vadim Petrozsky, HSE, Russian Federation

Editorial board

John Berry, Queen's University, Canada

Gershons Breslavs, Baltic International Academy, Latvia

Maria Falikman, HSE, Russian Federation

Elena Grigorenko, Lomonosov MSU, Russian Federation, and Yale Child Study Center, USA

Vasily Klucharev, HSE, Russian Federation

Anatoliy Kharkhurin, American University of Sharjah, UAE

Vladimir Lefebvre (University of California, USA)

Dmitry Leontiev, HSE and Lomonosov MSU, Russian

Federation

Martin Lynch, University of Rochester, USA

Dmitry Lyusin, HSE and Institute of Psychology of RAS,

Russian Federation

Evgeny Osin, HSE, Russian Federation

Alexander Poddiakov, HSE, Russian Federation

Vladimir Shadrikov, Deputy Editor-in-Chief, HSE, Russian

Federation

Dmitry Ushakov, Deputy Editor-in-Chief, Institute of Psychology of RAS, Russian Federation

Jaan Valsiner, Aalborg University, Denmark

Sergey Yagolkouskiy, Deputy Editor-in-Chief, HSE, Russian Federation

\section{Editorial council}

Ksenia Abulkhanova-Slavskaja, HSE and Institute of Psychology of RAS, Russian Federation

Nikolai Almaev, Institute of Psychology of RAS, Russian Federation

Vladimir Barabanschikov, Institute of Psychology of RAS and Moscow University of Psychology and Education, Russian Federation

Takhir Bazaroz, HSE and Lomonosov MSU, Russian Federation

Alla Bolotova, HSE, Russian Federation

Alexander Chernorisov, Lomonosov MSU, Russian Federation

Alexey Guser, Lomonosov MSU, Russian Federation

Anatoly Karpov, Demidov Yaroslavl State University,

Russian Federation

Alfried Ldngle, HSE, Russian Federation

Pietro Lucisano (Sapienza University of Rome, Italia)

Alexander Orlov, HSE, Russian Federation

Victor Petrenko, Lomonosov MSU, Russian Federation

Vadim Rozin, Institute of Philosophy of RAS, Russian

Federation

Igor Semenov, HSE, Russian Federation

Elena Sergienko, Institute of Psychology of RAS, Russian Federation Alexander Shmelev, Lomonosov MSU, Russian Federation

Peter Schmidt, HSE, Russian Federation, and Giessen University, Germany

Elena Starovoytenko, HSE, Russian Federation

Tatiana Ushakova, Institute of Psychology of RAS, Russian Federation

Anatoly Zhuravlev, Institute of Psychology of RAS, Russian

Federation

\section{PSYCHOLOGY}

of the Higher School of Economics
ISSN 1813-8918; e-ISSN: 2541-9226

«Psychology. Journal of the Higher School of Economics» was established by the National Research University «Higher School of Economics» (HSE) in 2004 and is administered by the School of Psychology of HSE.

Our mission is to promote psychology both as a fundamental and applied science within and outside Russia. We provide a platform for development of new research topics and agenda for psychological science, integrating Russian and international achievements in the field, and opening a space for psychological discussions of current issues that concern individuals and society as a whole.

Principal themes of the journal include:

- methodology, history, and theory of psychology

- new tools for psychological assessment;

- interdisciplinary studies connecting psychology with economics, sociology, cultural anthropology, and other sciences;

- new achievements and trends in various fields of psychology;

- models and methods for practice in organizations and individual work;

- bridging the gap between science and practice, psychological problems associated with innovations;

- discussions on pressing issues in fundamental and applied research within psychology and related sciences.

Primary audience of the journal includes researchers and practitioners specializing in psychology, sociology, cultural studies, education, neuroscience, and management, as well as teachers and students of higher education institutions. The journal publishes 4 issues per year. It is distributed around Russia and worldwide.

\section{Managing editor Yu.V. Briseva}

Copy editing O.V. Shaposhnikova, O.V. Petrovskaya, N.S. Sambu, D. Wansbrough

Translation into English K.A. Chistopolskaya,

E.N. Gaerskaya

Page settings E.A. Valueva

Editorial office's address:

4 Armyanskiy pereulok, build. 2, 101000, Moscow,

Russia.

E-mail: psychology.hse@gmail.com

Website: http://psy-journal.hse.ru/

No part of this publication may be reproduced without the prior permission of the copyright owner (C) HSE, 2018 r. 


\section{Vol. 15. No 4 2018}

PSYCHOLOGY

Journal of the Higher School of Economics

\section{CONTENTS}

\section{Special Theme of the Issue.}

\section{The Russian Psychologist: Architects of the Schools}

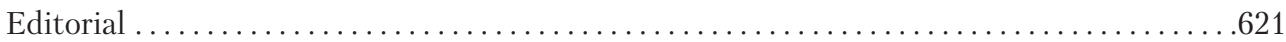

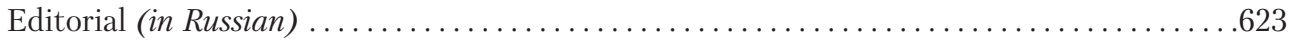

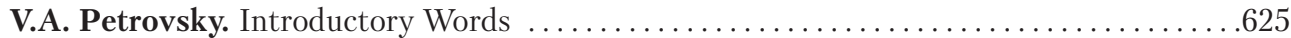

A.V. Petrovsky, V.A. Petrovsky. The Categorical System of Psychology. An Experience

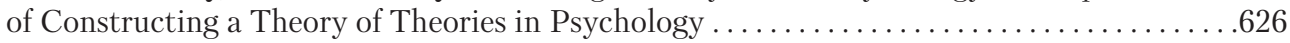

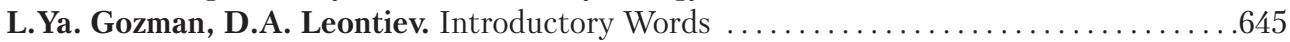

G.M. Andreeva, A.N. Leontiev. Methodological Problems in the Study of the Psychological Aspects of Social Change . . . . . . . . . . . . . . . . . . . . . . . . . . . . . . . . . . 646

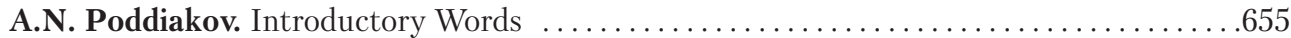

A.N. Poddiakov, N.N. Poddiakov. Interactive Exploratory Objects: From Laboratory

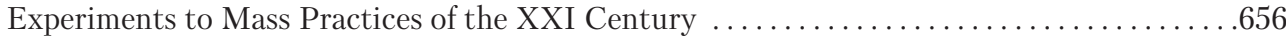

\section{Articles}

M.A. Bultseva, N.M. Lebedeva. The Role of Individual Values and Motivation in Creative Writing Productivity of Poets and Prose Writers (in Russian) . . . ..........675 RETRACTED, 01.02.2019 A.V. Yurevich. Psychological State of Modern Russian Society: New Trends (in Russian)

E.L. Grigorenko, S. Torres, E.I. Lebedeva, Y.A. Bondar. Evidence-Based Interventions for ASD: A Focus on Applied Behavior Analysis (ABA) Interventions . . . . . . . . . . . . . . 711

E.B. Starovoytenko. A Non-Dialogic Relation to the Other: Regression or Opposition to

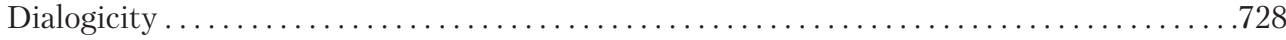

\section{Work in Progress}

N.M. Lapteva, E.A. Valueva, S.S. Belova. Priming Effects in a Lexical Decision Task 


\section{Special Theme of the Issue. The Russian Psychologist: Architects of the Schools}

\section{EDITORIAL}

In this issue, we will give the floor to the creators of prominent schools of psychological thought, - to A.N. Leontiev, G.M. Andreeva, A.V. Petrovsky, and N.N. Poddiakov.

Alexey Nikolaevich Leontiev was the author of the general psychological theory of activity, a close associate of L. S. Vygotsky and a thinker. He made a massive contribution to the development of Russian psychology. The paper published in this issue was written in collaboration with Galina Mikhailovna Andreeva, whose scientific works and textbooks are known to every professional psychologist in Russia. The subject of their paper is the change that takes place in society. It was written in the times when the 'change' could be least expected in Russia as it was still a long time until perestroika (unfortunately A.N. Leontiev passed away earlier). The paper, in the opinion of a modern reader, may have a somewhat unusual genre: it is rather a draft, a kind of development application, but neither a 'report', nor a 'list of results', nor a 'theory experience'. This genre was typical for the time. Here we witness a methodological outline, a sketch for the future that would guide the thought of researchers. A decade later, an article was written jointly by the two authors that found a real subject in the processes of the desired and, at the same time, as if unexpected, changes in Russian society. The reader will find detailed comments on the paper in a small introduction to the publication prepared by L.Ya. Gozman and D.A. Leontiev.

Artur Vladimirovich Petrovsky was a historian of Russian psychology, a social psychologist, the creator of the fundamental theory of the activity mediation of people's relationships within a team (the stratometric theory of the team). The last two decades of Petrovsky's life were devoted to the development of problems of personality psychology (among others, the three-factor model of the significant other, the ontological model of the personality, etc.). Together with V.A. Petrovsky there was a concept of the need and ability of personalization proposed, and, on this basis, a model of personal development). A.V. Petrovsky, as a methodologist of science, proposed the idea of theoretical psychology, the theory of psychological theories, and in the development of this idea - a model of the psychosphere (the categorical system of psychology). On the pages of the journal we will reproduce 
one of the last works of the scientist written in collaboration with V.A. Petrovsky. The work published is devoted to a system of categories in which "psychology reflexes itself".

Nikolai Nikolaevich Poddiakov. His work is widely known to the Russian public. Works by N.N. Poddiakov have been translated into German, English, Spanish, Japanese, Polish and other languages. Considering the interrelation of the processes of determination in the development of the psyche of a child by an adult and the children's own activities as determinants of the development, N.N. Poddiakov refers to the children's experimentation as to the child's leading activity, the basis for constructing, playing and other children's activities, the formation of a "naive dialectic", and the integrity of the mental life of children. In this issue we offer to the reader a paper by N.N. Podiakov co-authored by A.N. Poddiakov, who is the author of original research on children's search activity. The published paper is devoted to the problem of stimulating curiosity in children, and the active search for novelty and complexity.

Editorial Board 


\section{Специальная тема выпуска: «Российский психолог»: архитекторы школ}

\section{ВСТУПИТЕЛЬНОЕ СЛОВО}

В этом выпуске мы дадим слово создателям крупных научных школ в психологии - А.Н. Леонтьеву, Г.М. Андреевой, А.В. Петровскому, Н.Н. Подьякову.

Алексей Николаевич Леонтьев - автор общепсихологической теории деятельности. Соратник Л.С. Выготского. Мыслитель, внесший огромный вклад в развитие отечественной психологии. Публикуемая статья написана им в соавторстве с Галиной Михайловной Андреевой, научные труды которой и учебники известны каждому профессиональному психологу, живущему в России. Их статья посвящена изменениям, происходящим в обществе, и написана как раз тогда, когда «перемены» могли быть менее всего ожидаемы в России - до перестройки еще надо было дожить (А.Н. Леонтьев, увы, ушел из жизни раньше). Статья, на взгляд сегодняшнего читателя, может быть, несколько необычна по жанру: это - скорее проект, некая заявка на разработку, но отнюдь не «отчет», не «свод результатов», не «опыт теории». Такой жанр был характерен для времени написания. Перед нами методологический набросок, эскиз на будущее, ориентирующий мысль исследователей. Десятилетие спустя совместная статья двух авторов обрела свой реальный предмет в процессах желанных, и, в то же время, как бы нежданных перемен в российском обществе. Подробные комментарии к статье читатель найдет в небольшом введении к публикации, подготовленном Л.Я. Гозманом и Д.А. Леонтьевым.

Артур Владимирович Петровский - историк российской психологии, социальный психолог, создатель фундаментальной теории деятельностного опосредования отношений в коллективе («стратометрическая теория коллектива»). Последние два десятилетия жизни Петровского были посвящены разработке проблем психологии личности (среди них - «трехфакторная модель значимого другого», «онтологическая модель личности» и др.); совместно с В.А. Петровским предложена концепция потребности и способности персонализации и на этой основе - модель развития личности. А.В. Петровским, как методологом науки, была предложена идея «теоретической психологии» «теории психологических теорий» и в развитие этой идеи - модель «психосферы» («категориального строя психологии»). На страницах журнала мы 
воспроизводим одну из последних работ ученого, написанную в соавторстве с B.А. Петровским. Публикуемая работа посвящена системе категорий, в которых «психология рефлексирует себя».

Николай Николаевич Поддъяков. Своими работами он широко известен российской общественности. Работы Н.Н. Поддьякова переведены на немецкий, английский, испанский, японский, польский и другие языки. Рассматривая взаимосвязь процессов детерминации развития психики ребенка со стороны взрослого и собственной активности детей как детерминанты развития, Н.Н. Поддьяков описывает детское экспериментирование в качестве ведущей деятельности ребенка, основы конструирования, игры и других детских деятельностей, становления «наивной диалектики», целостности психической жизни детей. В настоящем издании мы предлагаем читателю статью, написанную Н.Н. Подьяковым в соавторстве с А.Н. Поддьяковым, автором оригинальных исследований, посвященных поисковой активности детей. Публикуемая статья посвящена проблеме стимуляции любопытства детей, активного поиска новизны и сложности.

Редакиия 


\section{INTRODUCTORY WORDS TO A.V. Petrovsky, V.A. Petrovsky. The Categorical System of Psychology. An Experience of Constructing a Theory of Theories in Psychology}

The background to this publication. The original paper on the categorical system of psychology contains two fundamental ideas on the existence of basic categories in psychology (M.G. Yaroshevsky) and metapsychological categories (A.V. Petrovsky). These ideas were developed in the final chapter of the book Fundamentals of Theoretical Psychology by A.V. Petrovsky and M.G. Yaroshevsky (M., INFRA-M, 1998) written by A.V. Petrovsky, V.A. Petrovsky and M.G. Yaroshevsky. Later A.V. Petrovsky proposed to "complete" the sequence of the described categories "from below" (biocentric and protopsychological categories) and from above (sociocentric categories). With the involvement of V.A. Petrovsky, clusters of categories (orientation, activity, cognitivity, bias, etc.) were also identified and designated, along with the unrelated "pleiads" of categories. Eventually a table of categories was created that reflects the forms of psychological cognition and the means of documenting various manifestations of a person's mental life - the categorical system of psychology that is interpreted by the authors as a result and a tool of self-reflection in psychology, or, metaphorically speaking, a "psychological tool" (in terms of L.S. Vygotsky) used by psychology to construct itself.

The paper on the categorical system of psychology was first published in the Issues of Psychology to provoke an active discussion in verbal and written presentations by Russian psychologists. The experts shared the view on a high academic significance of the work, but estimated it differently. One of these evaluations encourages us to offer a translation of this paper to readers who would prefer to read it in English: "Among separate publications I most enjoyed the one by A.V. Petrovsky and V.A. Petrovsky, as it is a quiet and totally rigorous narrative that lacks ritual lamentations about activity or, say, communication, who have constructed a matrix of the main psychological categories, where there was a place both for activity and communication, and for about three dozen of equally important concepts. It should be said that this approach responds to a greater degree to the spirit of modern global research than attempts to identify a universal conceptual unit, a cell of "everything" cells, which are also presented in the Russian psychological literature (B.M. Velichkovsky, An Open Letter to the Editors of the Journal Issues of Psychology, 2001).

It has been a long time since the publication of the paper. The categorical system was completed and refined, the discussion with opponents was extremely fruitful. However, in this case, with the kind permission of the editorial staff of the Issues of Psychology, we are publishing the translation of the original manuscript without any changes to it. 


\title{
THE CATEGORICAL SYSTEM OF PSYCHOLOGY. AN EXPERIENCE OF CONSTRUCTING A THEORY OF THEORIES IN PSYCHOLOGY
}

\author{
A.V. PETROVSKY ${ }^{\mathrm{a}}$, V.A. PETROVSKY ${ }^{\mathrm{b}}$ \\ ${ }^{a}$ Worked at Psychological Institute, Russian Academy of Education \\ ${ }^{b}$ National Research University Higher School of Economics, 20 Myasnitskaya Str., Moscow, 101000, \\ Russian Federation
}

\begin{abstract}
For decades, Soviet psychologists were engaged in the search for the cell (unit) of the psyche. The idea to transfer the 'goods' (the classical cell of the political economy of Marxism) into the sphere of psychological constructions seemed tempting. During the subsequent critical review, each of these "cells" has never emerged as the sole creator of the mental. The paper proposes a different interpretation of the mental world: it is formed not by a single "cell" in its development, but by a complex, multi-stage, internally connected, but qualitatively specific system of categories that finds sources for the development and internal organization in nature and society. The categories were inentified that form pleiads and clusters in theoretical psychology, the "theory of theories", in which psychology reflects itself. The pleiade of the categories of natural causality indicates phenomena that can be documented by objective methods, "from the outside" (biophysical data). The pleiade of protopsychological categories contains noumena (intelligible entities). A pleiade of basic psychological categories refers to phenomena that are available for introspection. The pleiade of metapsychological categories contains ideas (unity of the thought and the conceivable, self-fulfilling representations). The pleiade of extrapsychological categories are controversies (discretions that instigate a diverse reinterpretation of existence and the mutual criticism of ideas about it by different researchers). Each of the clusters of categories reflects a fundamental dimension of human existence. Such are substantiality (organism, being, subject, the I, personality); orientation (deficit, need, motive, value, ideal); activity (metabolism, reflex, action, object activity, freedom); cognitivity (signal, sensation, image, consciousness, mind); bias (selectivity, affectivity, experience, feeling, meaning); co-being (synergy, coexistence, interaction, communication, involvement); and reality (environment, field, situation, objectness, world). There are different logical mechanisms of the horizontal (pleiades) and vertical (clusters) integration of the categories inherent to the process of their theoretical synthesis, which reflects the logic of the phylo-, socio- and ontogenesis of human beings in their becoming and development.
\end{abstract}

Keywords: theory of theories, "cell”, natural causality, noumena, phenomena, ideas, controversies, substantiality, orientation, activity, cognitivity, bias, co-being, reality, ascent from the abstract to the specific. 
The identification of a system of categories in the historicism of psychological analysis enables the historian of psychology to shift to the position of being a developer of theoretical psychology.

When researchers define the principle of openness in the categorical system as one of the principles of theoretical psychology, they become capable of expanding basic categories by means of a psychological understanding of thought on other concepts that exist in psychology. New dyads can be built in a similar way: a basic category - a metapsychological category. For example, the four basic categories first introduced by M.G. Yaroshevsky (when describing the categorical system of psychology) are joined by two more - experience and subject (Yaroshevsky, 1974). Metapsychological development of these categories (based on other - basic - categories) can be found, respectively, in such categories as feeling and the $I$.

So, currently in the development of problems of theoretical psychology, there may be noted a possibility of an upward movement of specifying basic psychological categories towards metapsychological categories with varying degrees of generality and specificity. A number of correspondences emerge between basic and metapsychological categories:

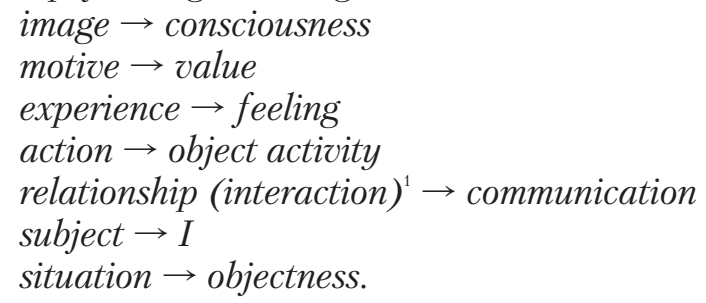

The ratio of basic and metapsychological categories defined below can be interpreted as follows: in each metapsychological category there is a certain basic psychological category revealed through its relation to other basic categories (allowing the identification of the 'systemic quality' within it). While in each of the basic categories, any other basic category exists hidden, 'compacted', each metapsychological category is a 'development' of these latent formations. The relationship between the basic categories of psychology can be compared with the relationship of the Leubinian monads: each reflects each. If we try to metaphorically express the relationship between the basic and metapsychological categories, it will be appropriate to mention the hologram: a part of the hologram (basic category) contains a whole (metapsychological category). To verify this, it is sufficient to look from a certain view point at any fragment of such a 'hologram'.

With regard to logic, each metapsychological category is defined through a unified subject-predicative construction, in which a certain basic category is in the position of a subject (to give an example: image as a basic category in the metapsychological category 'consciousness'), and the predicate is the ratio between this

\footnotetext{
${ }^{1}$ It seems to us that M. G. Yaroshevsky (1974), when introducing the psychosocial attitude as a basic category, intrinsically meant what could be more briefly referred to as relationship or interaction.
} 
basic category and other basic categories - motive, action, relation (relationship, interaction), experience.

Thus, the metapsychological category of consciousness is considered as the development of the basic psychological category image, and, for example, the basic category action takes on a specific form in the metapsychological category object activity, etc. The basic category, which functions as a logical subject of any metapsychological category, shall be called the categorical core, and the categories, by means of which this core category is transformed into the metapsychological category, shall be denoted as formative (specifying). The formal relationship between basic and metapsychological categories is shown in the figure.

It is shown in the Figure that in accordance with the principle of openness of the categorical system in theoretical psychology, the lines of both basic psychological categories and of metapsychological categories are open. This is explained by the fact that some categories are emerging only today (for example, the correlation situation - objectness); like all arising 'here and now', they happen to be still partly outside the actual self-reflection of science.

The proposed method of ascending to metapsychological categories based on the categories of the base level is further briefly illustrated by an example of correlating them.

Image $\rightarrow$ consciousness. Is consciousness a metapsychological equivalent of the basic category image? In recent literature there are opinions that exclude such a version. It is argued that consciousness is neither what A.N. Leontiev defined as "in its immediacy ... a picture of the world opening to the subject, that involves the subject itself, their actions and states," nor "a relation to reality", but it is "a relation in reality itself", "the totality of relations in the system of other relations"; it "does not have an individual existence or individual representation" (Leontiev, 1975). In other words, consciousness is supposedly not an image - the emphasis is

Figure 1

The relationship between basic and metapsychological categories. The basic (core) categories are linked with metapsychological categories by vertical lines in bold type, and the formative categories are linked by thin slanting lines

Upper level categories (metapsychological)

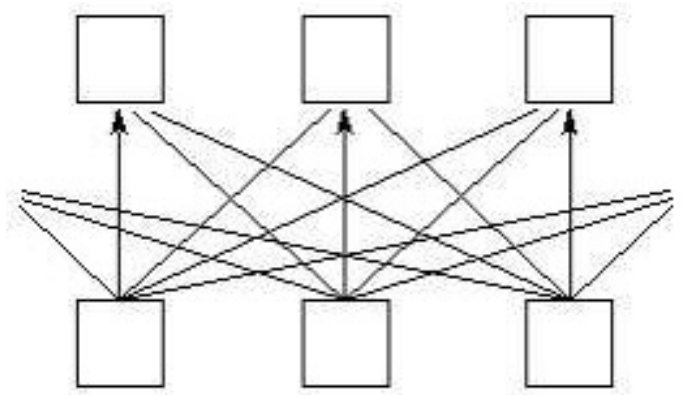

Lower level categories (basic) 
transferred to the category of relation. This view, as we believe, follows from a limited understanding of the category image.

The connection between the concept of image and the concept of idea that has a centuries-old tradition in the history of philosophical and psychological thought has been lost. The idea is an image (thought) in action, a productive insight that forms its object. The idea overcomes the opposition of the subjective and objective (it is quite reasonable to suppose that "ideas create the world"). When we identify in the image something which characterizes it on the part of effectiveness (and therefore, motives, relationships, and experiences of the subject), we define it as consciousness. So, consciousness is an integral image of reality (that in turn means the sphere of human action) that fulfills the motives and relations of subjects and contains its self-experience, along with the experience of the externality of the world in which the subject exists. So, the logical core of the definition of the category consciousness here is the basic category image, and the formative categories are action, motive, relationship, experience, and subject.

Motive $\rightarrow$ value. A test of the strength of the idea of ascending from abstract (basic) categories to concrete (metapsychological) categories can also be exerted using the example of the development of the category motive. In this case, a difficult question arises about a metapsychological category that should be aligned with this basic category: significance (N.F. Dobrynin), worthiness (N.I. Nepomnyaschaya), semantic entity, value orientations. However, though it is quite certain that all these concepts are aligned with each other and do correlate with the category of motive, they cannot (for various reasons) be considered the metapsychological equivalent of the latter. A way to solve this problem is to attract the category of value. When we require of values of a person, we ask about the hidden motives of the person's behavior, however, the motive itself is not yet a value. For example, you can feel attracted to something or to someone and at the same time be ashamed of this feeling. Can such urges be considered values? Yes, but only in the sense that these are negative values. This phrase should be recognized as derived from the original - positive - interpretation of the category of value (talking about "material and spiritual, objective and existential, cognitive and moral values,” etc.).

Therefore, value is not just a motive, but a motive that owns a certain place in the system of self-relations of the subject. The motive that is considered as a value appears in the subject's consciousness as the defining characteristic of its existence in the world. We are confronted with a similar understanding of value in both the ordinary and scientific consciousness (value in the ordinary word usage means a phenomenon, a subject that has a particular meaning, which is important and significant in any respect; in a philosophical plan the normative and evaluative nature of value is emphasized). Value is what a person, as G. Hegel puts it, recognizes as his or her own.

However, before a motive is perceived as a value by an individual, an assessment should be made, and sometimes even a reassessment, of the role that the motive plays or can play in the processes of self-fulfillment of the individual. In other words, in order for a motive to be included by the subject in the image of itself and 
to come forward, thus, as a value, the subject must perform a certain action (an act of value self-determination). The result of this action is not only the image of the motive, but also the experience of this motive by the subject as an important and integral part of him or her. At the same time, value is what the subject sees as valued by other people, i.e. that has a momentum for them. The subject is personalized through values (acquiring an ideal representation and continuity in communication).

Motives and values, being intimate, are actively exposed in communication in order to reveal the communicating people to each other. Thus, the category of value is inseparable from the basic category of relationship (interaction) that is considered in both only in the external and in the internal plans. So, value is a motive, which in the process of self-determination is considered and experienced by the subject as its own inalienable 'part' that forms the basis of the subject's self-presentation (personalization) of the subject in communication.

Experience $\rightarrow$ feeling. The category of experience (in the broad sense of the word) can be considered as a core one in the construction of the metapsychological category of feeling. S.L. Rubinstein distinguished between primary and specific experience (Rubinstein, 1998). In the first meaning (we consider it determining to establish one of the basic psychological categories), experience is viewed as an essential parameter of the psyche, the quality of belonging to an individual of what constitutes the inner content of the individual's life; S.L. Rubinstein when speaking about the primacy of such an experience, distinguished it from experiences "in a specific, emphasized sense of the word"; the latter have the characteristics of the event as they express the 'uniqueness' and 'significance' of something in the inner life of a person. We believe that such experiences constitute what can be called a feeling. Special analysis of texts by S.L. Rubinstein could show that the way of becoming an eventual experience (a feeling) is a way of mediation: the primary experience, that forms it, act in its conditionality from the image, motive, action, relationship of the subject. Therefore, considering experience (in the broad sense of the word) as a basic category of psychology, the category of feeling - in the logic of the ascent - can be viewed as a metapsychological category.

Action $\rightarrow$ object activity. Object activity is a metapsychological equivalent of the basic category of action. Object activity is a whole self-valued action (that has initially collectively distributed character). The source of activity is the subject's motives, its goal is the image of the possible (as a prototype of what will happen), its means are individual actions addressing intermediate goals and, finally, its result is an experience of the relationship formed by the subject with the world.

Interaction (relationship) $\rightarrow$ communication. The interaction category ( $p s y$ chosocial relation, relationship, interaction, communication) is a backbone (core) element in the construction of the metapsychological category of communication. As part of the dyad of the basic and metapsychological level, interaction acts as the communication of people. To communicate means to relate to each other, to contribute or not to contribute, while implementing each other's individual goals and consolidating already established or forming new relationships. The constitutive characteristic of relationship is the acceptance of another subject's perspective ('acting out' its role) and the ability to combine in thoughts and feelings the personal 
vision of a situation and the point of view of another and to act together with the other person. This is possible through certain actions. The purpose of these actions is the production of something shared (a 'third' something in relation to the communicating people). There are the following actions of the kind: communicative acts (information exchange), acts of decentration (putting oneself in the place of another) and of personalization (achieving a subject's reflection in another). The subject level of reflection involves the whole experience image of another person that creates additional urges (motives) for the partner.

Subject $\rightarrow$ I. In the logic of the 'ascent from the abstract to the concrete', the subject category can be considered as basic when constructing the metapsychological category of the $I$. The following understanding (definition) of the $I$ can be proposed: the $I$ is an idea of self-beingness (in terms of G. Hegel, "being-in-itself" and "being-for -itself") that is inherent to the subject. This concept includes the subject as much as its inherent image and the experience of itself in the system of relationships with other subjects in certain situations, as well as the processes of self-reflection and 'self-construction' as its internally motivated actions (self-worth of cogito and self-determination).

From the above it is clear that it would be a mistake to document only the described dyadic categorical grid as completed and final. The basic and metapsychological categories do not exhaust the categorical analysis of psychological cognition, the latter to be completed by showing that there is a unity of the phenomenon and essence in each of the psychological categories. This is the fundamental characteristic of the categorical system of psychology.

At one time, when trying to draw a line to demarcate a specific subject area of psychology, N.N. Lange introduced the concept of psychosphere designed to embrace the wealth and diversity of the phenomena in this science. Aligning Lange's views on the psychosphere with fundamental ideas of V.I. Vernadsky about the biosphere and the noosphere fosters an opportunity to understand and describe the true place of the psychosphere in a single space formed by nature and society. According to V.I. Vernadsky, the biosphere is an object activity shell of the Earth where the total object activity of living organisms (including human beings) manifests as a factor of the planetary scale and significance. Vernadsky, following E. LeRoy and P. Teilhard de Chardin, understands the noosphere as a new evolutionary state of the biosphere, in which rational human object activity becomes the crucial factor for the development of the former. It is typical for the noosphere to have a close relationship of the laws of nature and the laws of thinking and society. Hence, it is obvious that the psychosphere, while retaining its own unique objectness, integrates transformed processes that occur in the biosphere and the noosphere, in some cases being drawn to the former and in others - to the latter. This allows researchers of basic and metapsychological categories also to address the space of the biosphere, in the depths of which protopsychological categories have been formed that are essentially manifested in the basic categorical system of psychology. At the same time, the level of metapsychological categories contains the essential characteristics with respect to the extrapsychological categorical development determined by the specific characteristics of the noosphere. It follows that, 
for example, the need (a protopsychological category) acts as an essence, and the motive (a basic category) acts as a phenomenon in which this essence is revealed. In turn, the value (a metapsychological category) manifests in the ideal (an extrapsychological category). So, we can conceptualize the categorical system of psychological cognition as a grid that forms five levels of categories (of which the first is in fact not a psychological category, but it is essential in relation to the overlying psychological categories) - biological, protopsychological, basic psychological, metapsychological and extrapsychological - that cover the entire psychosphere as a whole and generate the total conceptual apparatus of psychological science. For example, the conditional vertical deficit - need - motive value - ideal includes the greatest variety of psychological concepts (instincts, desires, interest, inclination, value orientations, etc.).

The categorical system of psychology is rather fully described in the table 1.

There can be specified both parallels (pleiades) and meridians (clusters) of categories that are presented in order in the table. Describing the pleiades of categories, we will express here only two claims that require special explanations.

1. Each of the categories in any lines (for all its specificity) is inseparable from each other category of the same line (for example, the category of the $I$ in the group of metapsychological categories is inconceivable without a correlation with the categories of value, object activity, feeling, consciousness, communication, and objectness; the category of image (a pleiade of basic psychological categories) is inseparable from the categories of subject, motive, action, experience, interaction and situation).

The content of the categories within each of the five pleiades in the table lines has a special cognitive status. The bottom line of the table, i.e. a pleiade of biological categories, points to phenomena that can be studied by objective methods, 'from the outside', just as physicists study objects of their field of knowledge. The accumulated facts are interpreted on the basis of schemes of natural causality. The second lower line of the table - the pleiade of protopsychological categories encompasses what in the language of philosophy is designated as noumena - intelligible entities. Indeed, each of the corresponding objects is not directly given to the observer either in the readings of sensors, or even less by direct observation from outside. For example, even such a seemingly fully observable form of activity as a reflex cannot be understood without introducing special constructs, the nature of which eliminates the possibility of contemplating them (for example, Tolman's "intermediate variables", "moods" by M.Ya. Basov, etc.). In addition, in introspection the categories of this pleiade do not appear directly (for example, the need is revealed to us exclusively in the form of motives - the experienced impulses to action). In contrast to the pleiade of protopsychological categories, the next pleiade of the basic psychological categories contains phenomena that are more or less available to introspection. This is a pleiade of phenomena. This situation is true even in relation to such a difficult category as subject (we feel our subjectness when, for example, we make a choice between two possible actions, or when we suddenly err in our expectations, or when we intentionally act maladaptively towards unpredetermined outcomes of a possible experience, etc.). Metapsychological categories constitute a pleiade of ideas. Every idea is not just a 
$\frac{1}{\frac{0}{0}}$

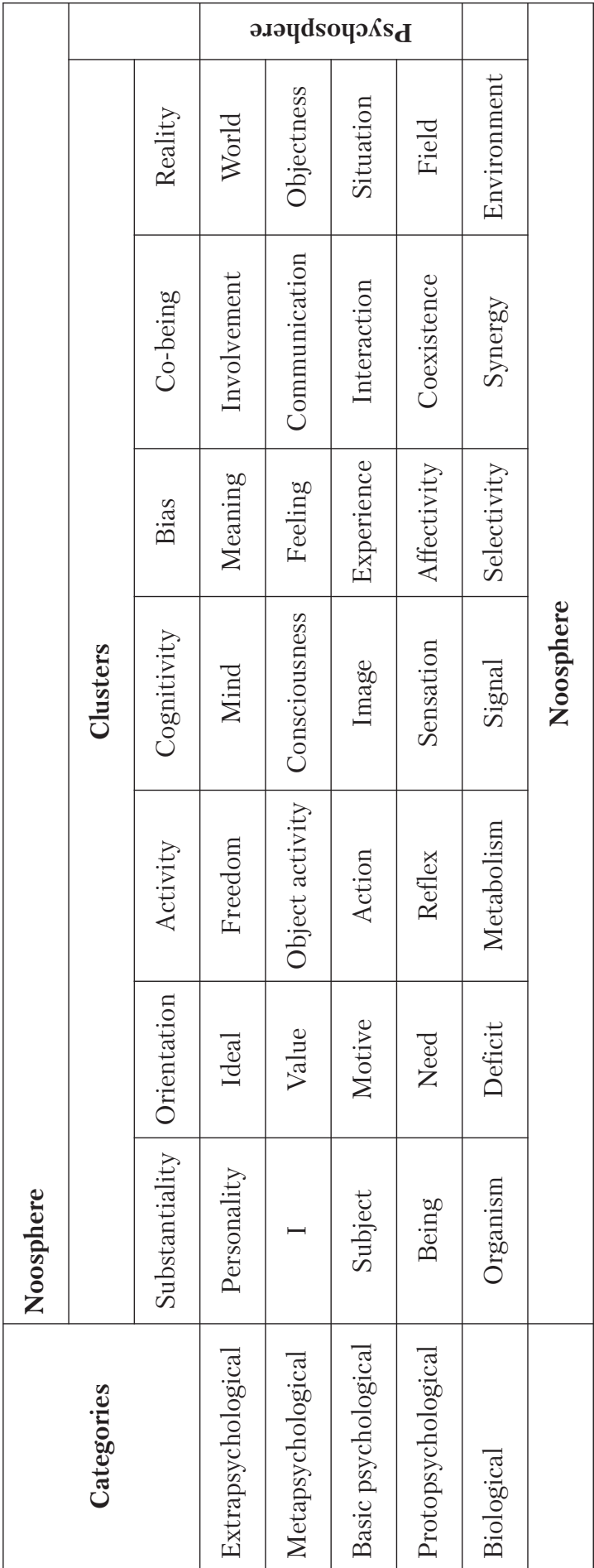


thought about something; it is a unity of the thought and the conceivable, a thought charged by the impulse of self-fulfillment. For example, the category the I. It represents the idea of the subject's self-reflection. And this means that the very thought of yourself as a subject capable of contemplating itself, experiencing, and thinking, create its I guiding the process of reflection. That is why it is impossible to study the I in the same manner as we study physical bodies. The $I$, value, object activity, feeling, consciousness, communication, and objectness are all ideas that create their objects. And finally, there is a pleiade of extrapsychological categories. The cognitive status of these categories is paradoxical. They seem to play hide and seek with the explorer. Any step of cognition here seems to repel the cognizable content; the object of the research enters into a competitive relationship with the researcher themselves proving that it cannot be reduced to anything that could be known in advance. Thus, imagine the pleasure of R. Cattell (one of the outstanding researchers of personality) in admitting his 'defeat' in attempts to 'understand' personality, when he says that personality is like love, everyone knows that it exists, but no one knows what it is. It is to be recalled that disputes about ideals, the fundamental impossibility of constructing an algorithm for creativity, personal meanings being resistant to attempts to translate them into an alien language, the sacredness of comprehending the world, the intimacy of co-participation, - all these are signs of special categories; they can be called controversy categories.

We shall now discuss in more detail the clusters of categories that form the columns in the matrix above.

Clusters of categories of the psychosphere (meridians, verticals, columns in the matrix). Each of the columns in the matrix contains a well-defined cluster of categories. We are talking about clusters of categories, because each of the verticals quite distinctly symbolizes one or another fundamental psychological dimension of human existence.

The cluster of substantiality unites such categories as organism (zero level), substance, subject, the I, personality (the highest level). Indeed, if we understand substance as what corresponds to this term in the history of human thought, namely, the property of being the fundamental principle of something that ultimately means "to be the cause of oneself" (causa sui), then one can be sure: this is the essence of all categories in the vertical. The property of substantiality at the same time reveals itself more fully during the transition from the bottom to the higher steps in this row. So, if the quality of self-causality in relation to an organism is revealed in a rather limited way and means 'no more than' the vitality of an organic body of a living being when interacting with the environment (the reproduction of its own bodily integrity), then when applied to human beings, this quality also means the transformation of the surrounding nature into the organic body of the person themselves (which implies both adapting to the natural environment and submitting it to one's own will). Exactly the same 'increase' in the force can be registered in all other cases considered, as we move upwards in each of the generic categories that cover any of the verticals. We shall concisely discuss each of the cases.

The cluster of orientation (synonymous with teleology, aspiration) is a series of categories that includes deficit (zero level), need, motive, value, ideal (highest 
level). The category of deficit that describes what is urgently needed does not mean that the organism has as already originally 'recorded' what is necessary for the existence - we can only talk about what the organism needs absolutely objectively; in other words, the latter may, so to say, 'have no clue' about its genuine interests, and even more so, in no way display them. As for need, it seems to assert itself with an activity (the need is 'dependence as a source of activity'). Next comes the category of motive; unlike need in general, a motive is nothing but a subjectivized aspiration - a phenomenal givenness of the need. Keeping on the vertical 'ascent', we discover value as a form of intentionality - here we witness the motive recognized by the individual themselves that has been transformed into the goal of their actions. And finally there is ideal, a value realized by the individual that directs their object activity, and moreover, is presented in communication as a model for all.

The cluster of activity summarizes such categories as metabolism (zero level), reflex, action, object activity, freedom (highest level). Here (as in other cases) the same logic of an ever more profound and significant disclosure of the generic definition of human existence is maintained. Each step of ascending within the cluster more and more fully reveals the category of activity. The proposed interpretation of activity unites the Kantian-Hegelian epoch and the ancient epoch in the philosophy of causality. In the definition of activity in general we follow the most succinct of all conceivable definitions that was given by Kant: "activity is the causality of the cause". The highest level of activity is the primal causality or, which is the same, free causality. In the development of Hegel's views, a free cause can be interpreted as the causa sui ('cause of oneself'), which gives us a general idea of the highest category of the cluster of activity (freedom). Such an understanding in relation to the categories of the psychosphere is specified in accordance with the teachings of Aristotle on four causes ('material', meaning something from which something is built; 'formal', something that provides a form for something built; 'efficient, what or who is building, and the 'final', for what something is being built) and the Hegelian understanding of the free cause.

Metabolism is the first level of the activity cluster. The organism reproduces its own corporeality, namely, what it consists of, the 'matter' of its being; in this case, we talk about material self-causality; here formal, efficient, and final causalities do not yet act independently: inside the body itself it is not 'recorded' in which direction, who and why will act. In order to imagine what is happening, we can use the analogy of the water cycle in nature: there is neither formal, nor efficient, nor final causality, and yet the material self-causality and the preservation of water mass is evident.

The second level of the cluster is reflex (a holistic reflex act of behavior). Reflex activity forms a condition for the implementation of metabolism, when the latter is impossible in the present or, if nothing changes, in the future. In these cases, the body performs a 'forward reflection of reality' (P. K. Anokhin) that restores or prepares the course of metabolism. Here we see the manifestations of formal causality that act independently as a condition for the existence of an organism (however, it is still too early to talk about the autonomization of the efficient and final causalities). It is interesting that the metabolism ensures the transformation of, as it were, 
a random, exploratory, one-time act of anticipatory reflection itself into a reflex by playing the role of reinforcement; as a result, not just the material composition of the organism but the integrity of a higher order is reproduced, - the body endowed with a reflex. Reflex contains formal self-causality (in the language of the concept of causality), which means the manifestation of freedom. The third level of the cluster is action. Action (arbitrary activity) comes to the fore when the free flow of a reflex act is impossible now or later without additional transformations of circumstances, and to ensure it a living creature should build an image of itself in the interaction with the environment (in addition to the image of it). In this case, the actual subjectness (who) - the efficient self-causality (that is another, higher manifestation of freedom) - emerges.

The fourth level is object activity. Here the very existence of the subject's ability to act is ensured, which constitutes the final landmark of activity - its final causality. It should be noted that object activity combines a variety of actions, the subjects of which may not be identical. In other words, the one 'for whom an object activity is performed, and the one 'who' acts is not necessarily an integral whole. Therefore, final causality can act here in isolation from efficient causality and, accordingly, formal and material causality. And finally, activity is successful only when it is reproducible; and this in turn indicates the final self-causality of activity, the subject's freedom in its implementation.

At the fifth, highest level of activity, the four causes act together, mediating each other, contributing to each other, belonging to each other and forming a true goal for each other, which means freedom.

The cluster of cognitivity (synonymous with ideality, imprintedness, representedness, reflectedness). This cluster includes the categories of signal (zero level), sensation, image, consciousness, and at the highest level, mind. All of these categories have in common the property of each denoting the fact that something is represented in something, the fact of 'being of a thing outside of the thing itself', as spoken of in philosophy. Tracing the path of ascent from the signal to the comprehension of the world, we see that the world is more and more opened up to the person, that the picture of the world is being freed from the oppression of immediate deficiencies, the dominance of needs, the bias of motives, and the guidance of human values. We observe the way the relatively simple ability of an organism to respond to a biologically significant impact (signal level) develops into a more complex and mysterious irritability of an individual to abiotic influences (the ability to sense), turns further into the subject's ability to perceive (appearance of images), comes further to the personal ability to be aware of the world and, finally, ascends to the stage of comprehending the world where the person can discover fundamentally different worlds that are fundamentally incomplete being widely open or concealed. We witness the steps of advancing to the truth (clear and distinct, genuine, authentic, universal or, on the contrary, unique knowledge).

The cluster of bias (synonymous with significance, subjectness). The term bias can be considered as a possible designation for the generic category that combines selectivity (zero), affectivity, experience, feeling and meaning (highest level). While selectivity is as yet completely 'unaddressed', objective, and teleologically neutral 
(although certainly not without a cause), the meaning encompasses a feeling of self-worth that is fully realized by the individual; the feeling not only expresses but also surpasses the private interests of activity and communication. These are only polar categories representing the attribute of bias; a special analysis can show how, when ascending along the meridian, the diverse manifestations of a human being are linked in the bias more and more densely and indissolubly. In essence, this is a matter of deepening the processes of subjectivization while ascending to the existential meanings.

The cluster of co-being (synonymous with sociality, community, involvement). This cluster includes the categories of synergy (zero level), coexistence, interaction, communication, and involvement (highest level). Ascending along the steps of this row is a transition from the idea of functional coherence and indissolubility of two parts of an organism or two creatures to the idea of autonomy and at the same time reflection of their being in each other (co-being at the coexistence level implies that individuals accept each other only to the extent that their presence may disrupt the natural manifestations of their own life activities (this is an existence 'near', but not 'together'). Co-being at the interaction level means mutual support, or, in other words, realization by at least one of the subjects of the instrumental function in relation to another (providing information, joining efforts, including physical effort, etc.). A commonality at the communication stage is, in fact, the result of the shared (as V. A. Petrovsky puts it). Such a production may not have the achievement of reflection, or presence, of a person in a person as its true goal. But if Heidegger's words are true that "the person is a presence", it should be recognized that 'human in a human being' can only be achieved at the highest level of co-being that is signified by the participation of people.

The cluster of reality includes the categories of environment, field, situation, objectness, and world. As one moves upwards vertically within the category, the categories more and more open up the area of existence. Environment is an area of physical and chemical prerequisites and results for the functioning of the body. Field is both a set of 'incentives' (in the paradigm of behaviorism) and field as a fundamental category of K. Lewin's theory; the field is an area of manifestation of the reflex (impulsive) activity of a living being. The term situation corresponds to such concepts as problem situation, problem (cognitive, existential, and the like), social situation of development (L. S. Vygotsky, L. I. Bozhovich); speaking of a situation, we emphasize that the subject is acting to resolve it by 'rising above it'. The next category is objectness (that is central for the development of the general psychological theory of the activity of A. N. Leontiev). And finally comes the most integral category - world (be it the version of S. L. Rubinstein, the author of the book Man and the World (Rubinstein, 1997), or the "life-world" by M. Heidegger). The world is "a multitude of worlds" (A. G. Asmolov); it can be said that the world is a unity of qualitatively unique worlds, that it is necessary to speak not only about multidimensionality, but also about the multi-worldness of the universe. To become a person means that the subject enters the "world of four worlds" (Nature, Culture, Communication, I myself), each of those being a projection of the universe that has significantly different laws of construction (for example, the parameters of space 
and time in these 'worlds' may have little in common with each other), while the highest level in discovering the world by a person is given to the latter in the experience of the "real infinity" of the understood.

Thus, we have attempted to give an extremely generalized and maximally brief description of clusters and pleiades that enable the description of the structure of the psychosphere.

It should be noted that each category of theoretical psychology is generic in relation to a certain range of psychological (in a broad sense) concepts. For example, the category of image can be specified in such terms as perception, presentation, imagination, memory, etc. Take, for example, the category of need. There are various ways of classifying human needs: according to their subject (material and spiritual needs), according to their origin (natural and cultural), although other 'rubrications' of needs are certainly possible. In some cases, it is quite challenging to choose specific concepts in relation to a particular category. For example, what are the conceptual and specific specifications of the category consciousness? It is interesting that due to the recent rather popular introduction of the notion of altered states of consciousness (altered consciousness), consciousness, so to speak, is normally not associated by psychologists with any special term (although psychiatrists use the exact phrase when speaking of a "clear state of consciousness", "clear consciousness"). We shall point out that in the proposed approach the differentiation of the types within the same category may be quite challenging. For example, the distinction between the subject of contemplation, the subject of thinking, the subject of experiencing, etc.

Along with the possibility of establishing genus relations that exist between particular categories and concepts (which indicates the diversity of psychological reality, and the richness of its forms), there is also a possibility of describing the conceptual architectonics in each of these categories, its internal structure; this tells us about the complexity of the psychological reality represented in the categorical model. We shall use the category of image as an example. Whatever psychological interpretations of the image we take, in any of them we are confronted with a number of concepts through which this category is meaningfully revealed. Here we have, for example, such constructs as "sensual fabric", "percept", "meaning" (Leontiev, 1975), or the forming a percept "primary sensory images" and "images of representation" about the world (Helmholtz), etc. The psychological structure of the $I$ category can be another illustration of what has been said about the conceptual architectonics of the categories. As it contains the idea of the subject's selfreflection, the category of the $I$ is meaningfully revealed, for example, through such concepts as self-assessment and the concept of I, or, say, in the concepts of the egostates of Parent, Adult, and Child (Bern), etc. etc.

The illustrations selected may seem too separated and fragmented; however, complete satisfaction could only be brought by an appeal to the entire conceptual apparatus documented in psychological dictionaries. It is easy to see that each of the categories forms the center of a particular psychological development, concept or theory, sometimes several conceptual systems (meanwhile, each of these theoretical developments contains a number of concepts, the connection of which forms 
the essence of the category). It is obvious that the very outlining of these concepts in this work is rather difficult, not to mention the 'calculation' of the concepts contained in these concepts. At the same time, it should be noted that this is the perspective that naturally opens up for theoretical psychology while it reaps the fruits from the 'beds' lined with the parallels and meridians of the psychosphere. No doubt, the authors consider it possible in the future, if necessary, to clarify the 'elements' of the proposed table. But this does not mean that the logic of the construction of the categorical system may change. This refers to the immutability of the defining principles of the interrelation of categories:

1) ascent from the abstract to the concrete by synthesizing system-forming/ core and formative categories;

2) essence as a phenomenon and the same phenomenon as an essence;

3 ) the counter determination of the psychosphere on the part of the biosphere and noosphere (biogenetic and sociocultural determination).

We shall note in this connection that some terms corresponding to the category elements in the table being developed are conditional and may be replaced by more successful ones in the future.

In the above table, three explanatory principles for the construction of psychological cognition are actually implemented: the principles of determinism, development, and systematicity.

The categories in each of the verticals of the table in their empirical implementation are determined from both the 'bottom' and the 'top'. Thus, the $I$ category (metapsychological) includes (in a discarded way) a biological basis, since it preserves the typological and individual features of the nervous activity of the organism. But at the same time, the priority determinant for this category (if we bear in mind its empirical content) is the noosphere that gives rise to countless variants of interpersonal manifestations. Thus, the conditionality on the part of the biosphere does not lose its power here, although the priority in this case undoubtedly belongs to cultural-historical determination.

The transition between categories is thought according to the pattern of ascent from the abstract to the concrete. To a certain extent the protopsychological line responds to the idea of preformism, it contains in a compacted form all the richness that reveals itself at a higher categorical level. In this case, the pivotal role is played by the category that is directly below on the vertical; it owns primacy over the category above it that has, respectively, the nature of a derivative. Formative categories act as conditions for 'germinating' the capabilities inherent in the categorical core. The value category, as was shown, is a direct development of the motive category as it is formed through the categories of experience, relation (interaction), action, etc.

The logic of the development of categories presents the real history of the development of the human race and of a specific individual, both sociogenesis and ontogenesis. The categories, which are built vertically and located along the four horizontals of the table, form the nodal points for the development of the psychosphere. Thus, the category of personality appears only at the highest stage of socioand ontogenesis, etc. 
In the above categorical grid, the principle of systematicity (so important for theoretical psychology), is fully represented. Unfortunately, many times and over the past two or three decades, the principle of systematicity, although declared as a priority for psychological science, has never received a concrete embodiment and theoretical justification. The general psychological signs and principles that form the system have not been described. The fact that the idea of the ascent from the abstract to the concrete has been fulfilled in the table is a sign of the systematic nature of this categorical grid. This process is represented by the provision on the preformalism of transitions between categories at different levels, by identifying the categories that have the character of primate and derivative, that are core and formative, and involved in the categorical synthesis. This is also found in the demonstration of the idea of ascending and descending determinism (represented by the provision on the empirical filling of each of the categories with the contents of the levels above and below that ultimately border the noosphere and the biosphere). Therefore, we can talk about the unity of sociogenesis and ontogenesis.

It remains only to directly indicate the general mechanisms of system formation. In this regard, it is proposed to distinguish between the mechanisms and the corresponding effects of the horizontal and vertical (synchronous and diachronic) conjugation of categories in the process of their synthesis.

The mechanism of horizontal conjugation (pleiade) of categories is based on the existence of systemic qualities that are objectively inherent in elements of the same level in the categorical grid. It is implied that, along with the explicit content that distinguishes each category on the horizontal line, there are (though hidden) some content caused by other categories of the same horizontal. An analogy arises with the principle of the full interaction of substances formulated by Kant (everything that exists at a given time contains definitions inherent in everything else that exists at the same time point). Each of the categories of the same level bears the imprint of other categories of the same level. Each category is an extremely saturated conglomeration of thick layers of countless empirical data observed by experimenters in hundreds of laboratories. They could use other words (for example, in Pavlov's school they discussed, for example, not need, but reinforcement, not affectivity, but about a "collision", etc.). But their categorical meaning, having been deciphered by the means of theoretical psychology, makes it possible to diagnose the role of the doctrine of behavior created in Russia in the development of the categorical stem of world psychological thought.

In the light of the above, we should focus on two circumstances. As shown by M. G. Yaroshevsky, the interpretation of behavior developed on the basis of Russian science, having influenced American psychology, acquired a special direction in it having turned into a behavioral version that prevailed in this psychology for the entire twentieth century. The second circumstance is connected with the need to distinguish between the behavior that represents the fundamental protopsychical standard of living and its neuromechanisms reconstructed in other, namely, physiological categories (the biological level of the categorical grid).

When considering any categorical level, we discover its pathogenetic aspect. If one of the categories located on the horizontal line falls out or is impaired, the sys- 
tematic quality of the categorical level is distorted, which affects all its other components.

All this enables observation of the possibilities in the categorical system that could address not only phylogenesis and sociogenesis, but also the pathogenesis of personality.

The categorical system of psychology cannot be grown from any one single 'grain'. This is especially important to emphasize, because every theoretical system (scientific school) of any significance in the history of psychology have been searching for a 'cell', which could be the starting point for building the overall configuration of the claimed teaching.

M.G. Yaroshevsky was the first scientist who explained the futility of this approach in the early 70s (Yaroshevsky, 1974). For adherents of the physiology of higher nervous activity such a hypothetical 'cell' was found in the conditioned reflex, in reactionology it was the reaction, in 'structural' psychology it was gestalt, in behaviorism it was stimulus - reaction, for early Freud it was libido, in the general psychological theory of A.N. Leontiev it was object activity, in the doctrine of D. N. Uznadze it was attitude, in the works of V.N. Myasishchev it was relation, etc. Apparently, feeling dissatisfied with the results of the search for such a 'cell', L.S. Vygotsky, the ideologist of these studies, consistently shifted from the speech reflex to the sign, then to the value, then the meaning and experience appeared. It is possible that if the life of this remarkable scientist had not been cut short so early, he would have rejected this in fact hopeless search and tried to find another theoretical solution. Not at all surprising is the persistence with which Soviet psychologists were engaged in the search for this sacramental cell of the psyche. It seemed more than tempting to transfer the classical 'cell' of the political economy of Marxism - the goods - into the sphere of psychological constructions. During the subsequent critical review, each of these 'cells' never appeared as the sole creator of the mental, which made it impossible to gain a complete picture of the mental world. The basis of the substantive interpretation of the psychosphere is not a single 'cell' in its development, but a complex, multi-level, internally connected, but qualitatively specific system of categories that finds sources for the development and internal organization in nature and society.

We shall point it out again: not a cell, even in its peak development, but a dynamic system of categories is able to embrace and reflect in itself the mental world of a human being. This also explains the rejected claim to build a single, all explaining theory of psychology. At the same time, it is expedient to try to preserve and realize the desire to construct a theory of theories of psychology.

The proposed project of theoretical psychology, as it can be assumed, contains the desired model of the theory of theories, a tool for resolving the historical crisis of psychology, which L.S. Vygotsky wrote about in those early years. We are talking about a categorical approach in the construction of a theory of theories in order to avoid duality in the interpretation of this phrase. However, another version of what the theory of theories should be like and what it should serve is quite possible: for example, to reveal the laws of the spontaneous formation of theoretical systems, the invariants of movement of psychological concepts and schools. A typical illustration 
of such a movement is the destiny of psychoanalysis, reflexology, Gestalt psychology and personalism in the understanding of L.S. Vygotsky, the author of the Historical Meaning of the Psychological Crisis: "These destinies that are as similar as four drops in the same rain attract ideas along the same path" (Vygotsky, 1982). L.S. Vygotsky describes in detail the internal logic of the movement of an idea, and the natural stages of its origin and extinction. The idea of the inevitable logic in the movement of scientific thought illustrated by 'developed sciences' was very actively and fruitfully discussed in the works of G.P. Schedrovitsky and his school (the idea of historical theory of solving scientific problems, and genetic reconstruction), as well as in the works of other prominent philosophers. In this understanding, the theory of theories would target us to analyze and summarize tendencies, which, as we should emphasize once again, spontaneously manifest "with such surprising regularity, constancy, with such regular monotony in various fields, that they positively allow the prediction about the development of a different concept or discovery, of an idea" (Vygotsky, 1982). But speaking of the theory of theories, we hold a different view (however, it is fully compatible with the first perspective). We see in it not only a generalization and not only the principle of the construction of psychology as an integral field of knowledge. The idea that the 'cell' of the categorical system of psychology (and we are talking about each category, starting with the protopsychological categories), is woven from system-forming and formative linking threads that emanate from the 'cells' of the underlying level, is reason to think about the extent to which these connections are theoretically and empirically developed. Defining the category of value, we should, for example, refer to the categories of motive, subject, action, image, experience, interaction, and situation. It is quite probable that, purely formally, this and other similar definitions could involve all the categories listed. But the following question is quite legitimate: have the proposed definitions already been ensured by any available psychological developments? It is absolutely clear that the elaboration of intercategorial connections (the subject of specific studies) and the predetermination of such connections (the methodological function of the categorical table) are far from being similar. The search for the relevant theoretical and empirical arguments in favor of the proposed definitions (which is necessary to establish a general view, to build theoretical psychology) is at the same time the development path of each of the specific areas of psychological knowledge. Theoretical psychology, in its categorical interpretation, is called upon (with reference to each specific theory) to answer the question: what this theory is for psychology as a whole, and what psychology as a whole is for each given specific theory.

L.S. Vygotsky, while developing the foundations of a new general science, thought of creating a special tool (instrument) that would allow him to master the practice of psychological knowledge. The future will show whether the categorical model of the theory of theories proposed by us is such a sought-after tool of knowledge, whether it fulfills the task of integrating and developing private psychological research. 


\title{
References
}

Vygotsky, L. S. (1982). Istoricheskiy smysl psikhologicheskogo krizisa [The historical meaning of the psychological crisis]. In L. S. Vygotsky, Collected works (Vol. 1, pp. 291-436). Moscow: Pedagogika.

Leontiev, A. N. (1975). Deyatel'nost'. Soznaniye. Lichnost' [Object activity. Consciousness. Personality]. Moscow: Politizdat.

Rubinstein, S. L. (1998). Osnovy obshchey psikhologii [Fundamentals of general psychology]. Saint Petersburg: Piter.

Rubinstein, S. L. (1997). Chelovek i mir [The person and the world]. M.: Nauka.

Yaroshevsky, M. G. (1974). Psikhologiya v XX stoletii [Psychology in the XX century] (2nd ed.). Moscow: Politizdat.

Artur V. Petrovsky (1924-2006) - full member, Russian Academy of Education (RAE), president of the RAE (1992-1997), D.Sc., professor.

Research area: history of psychology, social psychology, personality psychology.

Vadim A. Petrovsky - professor, Department of Psychology, Faculty of Social Sciences, National Research University Higher School of Economics, Member of the RAE, D.Sc., professor.

Research area: personality psychology, consultative psychology, mathematical modeling of behavior and consciousness.

E-mail: petrowskiy@mail.ru

\section{Категориальная система психологии. Опыт построения теории теорий психологии}

\author{
А.В. Петровскийа, В.А. Петровский \\ ${ }^{b}$ Работал в Психологическом институте Российской академии образования \\ ${ }^{b}$ Национальный исследовательский университет «Высшая школа экономики», 101000, Россия, \\ Москва, ул. Мясницккая, д. 20
}

\section{Резюме}

Советские психологи десятилетиями были заняты поисками «клеточки» («единицы») психического. Представлялась соблазнительной идея перенести в сферу психологических построений классическую «клеточку» политэкономии марксизма - «товар». В ходе последующего критического рассмотрения каждая из этих «клеточек» так и не выступила единственным созидателем психического. В статье предлагается иная интерпретация психического мира: его образует не отдельно взятая «клеточка» в ее развитии, а сложная,

Настоящая статья была опубликована на русском языке в журнале «Вопросы психологии», 2000. № 5. 
многоступенчатая, внутренне связанная, но качественно своеобразная система категорий, находящая источники своего развития и внутренней организации в природе и обществе. Выделены и соотнесены категории, образующие «плеяды» и «кластеры» теоретической психологии - «теории теорий», в которой психология рефлексирует себя. Плеяда категорий «естественной причинности» указывает на явления, которые могут быть зафиксированы объективными методами, «извне» (биофизические данности). Плеяда протопсихологических категорий содержит в себе «ноумены» (умопостигаемые сущности). Плеяда базисных психологических категорий характеризует явления, доступные интроспекции, - «феномены». Плеяда метапсихологических категорий - это «идеи» (единство мысли и мыслимого, самоосуществляющиеся представления). Плеяда экстрапсихологических категорий - «контроверзы» (усмотрения, провоцирующие многообразное переосмысление сущего и взаимную критику представлений о нем со стороны разных исследователей). Каждый из кластеров категорий характеризует то или иное фундаментальное измерение бытия человека. Таковы - субстанциональность («организм», «существо», «субъект», «Я», «личность»), направленность («нужда», «потребность», «мотив», «ценность», «идеал»), активность («метаболизм», «рефлекс», «действие», «деятельность», «свобода»), когнитивность («сигнал», «ощущение», «образ», «сознание», «разум»), пристрастность («избирательность», «аффективность», «переживание», «чувство», «смысл»), со-бытийность («синергия», «сосуществование», «интеракция», «общение», «сопричастность»), действительность («среда», «поле», «ситуация», «предметность», «мир»). Различаются логические механизмы «горизонтального» (плеяды) и «вертикального» (кластеры) сопряжения категорий в процессе их теоретического синтеза, что отражает логику фило-социо-онтогенеза человека в его становлении и развитии.

Ключевые слова: теория теорий, «клеточка», естественная причинность, ноумены, феномены, идеи, контроверзы, субстанциональность, направленность, активность, когнитивность, пристрастность, со-бытийность, действительность, восхождение от

Петровский Артур Владимирович (1924-2006) - действительный член Российской академии образования, президент РАО (1992-1997), доктор психологических наук, профессор. Сфера научных интересов: история психологии, социальная психология, психология личности.

Петровский Вадим Артурович - профессор, департамент психологии, факультет социальных наук, Национальный исследовательский университет «Высшая школа экономики», доктор психологических наук, профессор, ординарный профессор НИУ ВШЭ, член-корреспондент РАО.

Сфера научных интересов: психология личности, консультативная психология, математическое моделирование поведения и сознания.

Контакты: petrowskiy@mail.ru 


\section{INTRODUCTORY WORDS TO G.M. Andreeva, A.N. Leontiev. Methodological Problems in the Study of the Psychological Aspects of Social Change}

This paper was written 45 years ago. This is an immense time for any science. It has only been published once, in the Hungarian language, in the Journal of the Hungarian Academy of Sciences: Leontiev A.N., Andreeva G.M. Metodológiai problémák a társadalmi változások pszichológiai vonatkozásainak kutatásában // Magyar Pszichológiai Szemle. 1974. XXXI kötet. Szam 1. 6-14. This text is published based on the typewritten manuscript in English from A.N. Leontiev's archives. In the English manuscript, the surname of G.M. Andreeva is mentioned first, unlike in the Hungarian publication.

There is a footnote in the Hungarian publication that states: "a lecture given at the 3rd European Conference on Social Psychology”. Probably, this was a conference of the European Association of Experimental Social Psychology (EAESP). It was officially established in 1966, the third conference was held in 1972 at the University of Louvain in Belgium that A.N. Leontiev visited more than once. Presumably we may associate the text to this EAESP meeting, although we failed to find any mention of Soviet psychologists taking part in it.

This text is also interesting in the context of the logic of social change in our country. It is important not only WHAT is written, but also WHEN it was written. The year 1972 was just between the Prague and the Afghanistan events; it was the peak of stagnation. This was when Solzhenitsyn was expelled. The authors raise the issue of social change in a country whose authorities make every effort to ensure that nothing would ever change, where the destined future would flow from the past (which is not to be discussed); the country in where is immutability was really the highest value.

Any changes not foreseen by the five-year plans were seen as suspicious and, in general, hostile to the existing order of things. When ten years later the St. Petersburg sociologist Andrei Alekseev placed a question in a questionnaire designed for workers: "Do you expect any change?" he nearly lost his freedom. Well, the famous line Changes are wanted by our hearts was perceived as a hymn of a revolution. Perhaps due to at least an ambivalent attitude both to the problem of social change and to contacts with Western colleagues, this text was not published then either in English or in Russian.

The authors of this paper were no revolutionaries. But they were outstanding intellectuals, and their understanding of reality could not be limited by either formal prohibitions or informal hints. They were aware that change (for better or for worse) was inevitable. Therefore, this text appeared. 


\title{
METHODOLOGICAL PROBLEMS IN THE STUDY OF THE PSYCHOLOGICAL ASPECTS OF SOCIAL CHANGE
}

\author{
G.M. ANDREEVA ${ }^{\mathrm{a}}$, A.N. LEONTIEV ${ }^{\mathrm{a}}$
}

${ }^{a}$ Worked at Lomonosov Moscow State University

\begin{abstract}
The paper introduces the concept of social change in the context of social psychology. There are three levels of social change. (1). Radical transformations of the type of social relations and the economic formation through social revolutions. (2) System-level changes of specific domains of social practice such as education, mass communication, etc.. (3) Changes affecting vital activities of small groups or separate individuals. The psychological aspect of social change (especially of the two upper levels), is limited by the study of the individuals' perception of these changes, which sets the limits of competence for psychology in studying macro changes. However, the third level of social change makes the field of both social and, incidentally, general psychology. The specifics of the psychological study of social change at different levels is associated with different layers of methodology ranging from a general philosophical basis to special methods of research; the contribution of different layers of methodology varies across the levels of social change. The issue of resistance to change also requires different treatment depending on the level of analysis. Also discussed are the possibilities and limitations of an experimental research strategy. Lack of recognition of a broader social context is stated as a weakness of contemporary social psychology that needs to be corrected. Focusing on changes would bring social psychology closer to life problems, because the human situation in general is always a social and a changing one. Facing the challenge of change, an individual is involved with an inner conversation or an inner struggle to adapt to the change while maintaining personal self-esteem.
\end{abstract}

Keywords: social change, levels of methodology, resistance to change, experimental strategy, social context, human situation.

As an independent field of study, the concept of social change has no place, strictly speaking, in the subject matter of social psychology. In the existing division of sciences, social change is primarily a problem of sociology. Therefore, before elucidating the specific interest of the psychologist in the investigation of this problem, we should 'apply' the answers that sociology gives to it.

Here too, as is well known, not all researchers employ the concept of social change with the same meaning. First of all, there is a difference in the principle between the approaches to the essence of social change within the Marxist and non-Marxist conceptions of sociological knowledge. But there is also non unanimity among researchers who generally accept the treatment of the problem that is traditional in the West, as well as in their evaluation of various degrees of social 
change. In social psychology it is impossible to study it, unless we define what we have in mind when we use this fairly broad and undefined concept.

As a minimum we can, it would seem, distinguish three quite different levels of social change possible in society and, accordingly, three possible scales of investigating them.

The first level is linked with the broadest interpretation of social change, when we have in mind the radical transformations of the type of social relations expressed in social revolutions in transitions from one socio-economic formation to another, and so on. It is here that the Marxist sociological tradition considers another conceptual apparatus to be much more pertinent, one that discloses the social content and political form of the transformations taking place. Moreover, great attention is paid here to the problem of the trend or tendency of this change, and the concept of social progress is employed.

The second level is the changes that occur within the confines of a single type of society and concern separate aspects of the social organism: economies, cultures, techniques, or even narrower spheres, such as systems of education, systems of mass communication, and so on. For this level it would be necessary to introduce major amendments to the term "social change" since even in connection with these specific fields of change, it is too general and formal, because it does not pin down the connection between social change and the main features of the socio-economic system in the conditions of which the change is taking place.

Finally, the third level is the whole field of changes that refer to the vital activity of any social group, including small groups and also separate individuals. In this case the category "social change" essentially embraces the individual changes widely studied in social psychology, for example attitude change, changes in cognitive structures of the personality, and so on.

In this connection we would like to comment on Prof. Taifel's statement that social change should be understood as a certain fundamental characteristic of the social environment, that is to say not simply transformations of the technological, social and political structures but also the "ontogenetic phenomenon", i.e. the definite movement of the individual's activities and reactions during his or her whole life in connection with alterations in the environment (Israel \& Tajfel, 1972). There is no doubt that the set of questions described by that is not only important in it itself but is also significant for analysis in social psychology. But it is difficult to include it also under the term of social change.

The classification of social change proposed above, though fairly approximate, is quite necessary to our view before we can begin to define the 'limits' of the psychological approach to studying the problem. The three levels of social change described enable us now to formulate the positions from which their study by the social psychologist will be justified. However vague and undefined the term "social change" may be, the circle of the phenomena of objective social reality embraced by it is very significant in social psychology. Two aspects may be distinguished, which are particularly important for investigating the determination of social behaviour.

First, any social change considered at the first two levels, naturally also includes corresponding changes in the psychology of large social groups, in particular of 
classes, and in the consciousness of separate individuals. The subject of the analysis in this case may be both the perception of the objective changes by an individual or a group and the change itself as an activity of individuals or groups under the effect of these objective changes. There is a great variety of different trends of research here: the spheres of production, culture, education, the family, and so on.

On the other hand, every objective change in the life of society involves changes as a consequence in one or another of the forms of human communication and interaction traditionally studied by social psychology. Inter-group relationships are altered in accordance with the general character of the social relations; for Marxism relations between classes and between nations are particularly important here (in the second case it is interesting to trace how people's concepts of one another, and in particular ethnic stereotypes, are 'set' by the relations that arise between ethnic groups in new conditions of social development). It is also easy to show that such processes as urbanization, for example, also considerably modify forms of communication; the processes of communication in turn are largely determined by technical innovations and the structure of means of mass information.

These two aspects of the connection between social changes and changes in people's consciousness would seem to be what we may define as 'the psychological aspect of social change'. In this key social psychology turns to study social change at the macro-level as it can hardly pretend to do more. The very structure of social change, the pauses bringing it about, and its objective social consequences are a subject for sociological analysis, and no 'psychologizing' of this objective aspect of social change can be considered a suitable methodological position. Our thesis on this point is that psychological reductionism is also becoming discredited in the analysis of social change as in the analysis of other social relationships. The 'prestige' of social psychology is not diminished by the limiting its sphere of interest. On the contrary, the methodological principles of its approach become the more significant, the more clearly and relevantly the object of investigation is lineated.

There is also the third 'block' of social change within the social psychology, framework, though applying the term 'social change' to it is disputable. This is a broad circle of phenomena, including changes in individual and group positions, views, convictions, attitudes to very local objects, other people, and features of the environment, etc. Without clinging to the term, it can be agreed that this 'block' is a real field of social psychology, and also, incidentally, of general psychology. In practice it may take in any psychological research, since psychology deals with changes in the psyche. Problems of changes in cognitive behaviour have proved more rewarding in social psychology, and the sphere of changes of attitude has even acquired the status of an independent field of research. In all theories of balance the process of change in cognitive structures figures as a direct regulator of social behaviour, be it Heider's p-o-x model, Newcomb's theory of communication, or Festinger's theory of cognitive dissonance. In the last, the conceptual apparatus is worked out in detail, for example for analysing the form of resistance to change arising during the reduction of cognitive dissonance. One may, of course, give an interpretation to the whole aggregate of the processes of socialization in terms of 'change'. And as we know, it has been suggested in recent years, especially in con- 
nection with the publication of Toffler's Future-Shock, that the whole problem of adaptation should interpret the term of change; the outlook for the mental health of a person is defined in accordance with the limits of the changes to which he or she can adapt themselves (Toffler, 1970).

Even if we take the apparatus of concepts of "change" in this field as a general conceptual framework, its usefulness as such has still not, in our view, been demonstrated - many new conceptual amendments and qualifications are required so that research can be completed and not limited to the artificially created confines of a rigid conception embracing heterogeneous phenomena under the single term "social change".

The general scheme proposed here for the psychological approach to studying the problems of "social change" has a direct connection with developing methodological principles of the analysis. Some of these principles are quite common, but nevertheless need to be recalled. First, it is necessary to agree on what we mean by "methodology". The interpretation of this term (quite common for a long time in the West as a synonym for methods and procedures) has now become obsolete to a considerable extent. "Methodology" is coming more and more to embrace not only the methods and techniques of research but also a wider round of logical and methodical principles of the structure and organization of knowledge; and with it there is a noticeable tendency to interpret these principles not as purely formal norms of the structure of knowledge but to include analysis and the substance of analysis, for which it is necessary to pose a number of epistemological problems. As regards the Marxist tradition of investigating the process of cognition, it is convenient here to distinguish three levels of methodology: (1) the general methodology of scientific knowledge represented by a definite philosophical method, in Marxism in particular the method of dialectical materialism; (2) the special (or individual) methodology of each separate sphere of knowledge (e.g. the methodology of psychology, or social psychology, and so on), represented by the concretization of the general philosophical method as applied to a given field of knowledge (or a discipline).

At this second level the principles for analyzing the given subject-matter of the field are formulated, being developed on the basis of the more global, more general principles contained in the philosophical method adopted. For example, the special methodological principles adopted by the Soviet school of psychology is the principle of activity, or the principle of the historically conditioned psyche. This means that the basic content of the epistemological problem, for example, the standpoint of analysis of its socio-historical determinant, given is that the personality is interpreted at once as the object and as the subject of social relations. A hypothesis in social psychology is consequently formulated on the condition that a certain definite Image of Man and Image of Society, and some definite type of relationship between them, are adopted. The logical norms for formulating a theory or for designing an experiment, and the means of verifying a hypothesis are drawn up on a definite model (as regards content) of some phenomena or other in social psychology. 
(3) The third level of methodology is its traditional understanding as an assemblage of methods, techniques, and procedures of research. The elaboration of concrete scales for measuring attitudes, to take the example of a component of methodology at this level, also cannot be discussed in isolation from the more general principles accepted in research. It is at this higher "stage" of methodology that the technical methods of research are linked with the initial theoretical promises.

If we now pass on to formulating methodological principles acceptable in social psychology for analyzing the psychological aspects of social changes, we should first conclude that the various types of task arising in these studies call for the inclusion of a different combination of mythological principles in each specific case. The general philosophical approach of the researcher remains the same, unless his or her position is eclectic. But, social psychologist's concrete methodological equipment must differ whether he or she proposes to analyze the psychological aspect of mass social movements or, for example, changes in the concept of the 'Other' during the socialization of a child.

Transfer of the concepts that we employ to describe individual changes (or, to use Toffler's term, "vital changes") in attitudes, cognitive structures, etc., to the field of macro-social changes is not, in our view, methodologically admissible. "Resistance to change" in the theory of cognitive dissonance is clearly not identical with "resistance to changes", if by that we understand the psychological position (attitude) of some social group or other to changes taking place in the economic field or in the system of education in society as a whole. The complex of causes behind "resistance to change" can only be analyzed in any way fully provided that the content and level of the changes are properly described. In the opposite case we are again easily brought back to psychological reductionism, and begin to explain a change in the psychology of social groups through the prism and in the terms of change in the attitude or position of the individual. The complex of causes lying behind the development of the "resistance to change" in itself includes factors of a different degree of generality, depth, and significance. The special methodology of research in social psychology must be quite flexible in the sense of opportunities for applying it at various levels of analysis.

The special problem (and generally in research in social psychology) is one of the possibility of an experimental strategy in studying the psychological aspect of social changes. There has been no lack of discussion in recent years on the theme of the fate of the experiment in social psychology. The 'sterility', especially of laboratory experiments, is not simply associated with the 'vacuum', in which they are carried out, but also (as Prof. Tajfel has shown) is linked with their inability to predict social behaviour in conditions of change. This 'charge' is so vital that we must discuss the question in more detail.

The problem of how far the strategy of research in social psychology can be an experimental one means the following on the plane of the problem of 'social change': can the whole complex of problems relating to the 'psychological aspect of social change' only be grasped by means of experimental method? If we agree with the definition of its content proposed in the present paper, the answer can only be negative. As a matter of fact, the perception of macro-social changes in large social 
groups, and the changes in their psychology under the impact of these changes, cannot be adequately described solely by experimental methods. Furthermore, the laboratory experiment is practically excluded for all general purposes in a number of cases when we are concerned with big social groups.

But in that case is a strategy of experimental research justified in analyzing changes affecting attitudes, individual views, and the cognitive structures of the individual? There is a tendency in criticism of the limited character of experiment in social psychology, we know, to throw doubt on the possibility of forecasting social behaviour in an experiment, since no extrapolation of the conclusions to objective reality can take the factor of the changes into account taking place in that reality (and that will take place in it). Thus a most important determinant of social behaviour is excluded in principle. This objection is vital; but, in our view, is more significant in itself than in regard to the problem of social changes. Let us explain our idea.

In general it should not be claimed that laboratory experiments that record change in the individual's attitude can be considered a method of research in social psychology. It is a legitimate method in general psychology, the purpose of which is to study the mechanism itself of a change of position, attitude, views, etc. In evaluating the possibilities of laboratory experiment in research in social psychology, serious logical confusion creeps in; the debatable statement that any individual change can be taken as a social change is presented as indisputable. And then a method suitable for analyzing individual changes is declared inadequate for analyzing real social changes. In fact, what is criticized here is not the method but the false initial theoretical reasoning. It will be quite clear from this example that the blurring of the term 'social change', and the introduction under it of too wide a round of essentially different phenomena, does not help us to develop the methodological principles of research for what may be classed as the 'psychological aspects of social change'.

It is just the same, in our view, with the exaggeration of the idea that the outlook for transforming social psychology into a more mature and developed science is linked simply with its recognition as the main discipline investigating social change. When the vast bulk of work, especially of experimental research in contemporary social psychology, is criticized in particular for its lack of 'socials context', for the philosophical and methodological 'irresponsibility' observed in it, and finally for the avoidance everywhere felt in it of the moral and ideological collisions of our times, one can agree. But it is hardly serious to expect that all these deficiencies will automatically be overcome if only social psychology turned its attention to social changes. The fact that this problem is vital and significant can hardly be disputed. It is just as unlikely that the idea can be rejected that the times and society must dictate (its) (their) problems and tasks to science, and in particular to social psychology, and stimulate it to develop new methods of research, and not the other way round, to force the problem into the framework of already existing methods. Nevertheless, by simply recognizing social change as a most important factor in the life of society in the twentieth century, and by simply drawing attention to it from 
the side of social psychology, we will obviously not have it cured of all its inherent weaknesses.

We must seemingly seek out the still unrealized possibilities of social psychology in the very principles of the organisation of scientific knowledge, We suggest that the high road for its development lies along the line of carrying out in practice the principles of social knowledge developed by Marxism and real mastery of all the gains of psychology.

Having this perspective in mind we deem it important to have the notion 'change' in social psychology and in psychology in general. It is a new life situation in which human beings reveal themselves primarily as personalities. A human situation is always in fact a social and changing one. Therefore, the research of change will really bring social psychology closer to life problems.

There are, of course, still great difficulties to overcome in programming such types of research, in singling out real problems. We do not pretend to raise all these problems, but we would like to draw your attention to some theoretical assumptions which to our mind should be taken into consideration.

I. Although human beings are always the subject of social change, they are nevertheless each time confronted with change that has already emerged. Here the question inevitably arises: in what frame of reference is it possible to adequately describe the reaction of the individual and of the group to this change. Behaviorism describes it in such terms as adaptation conditioning and reinforcement. According to the opposite point of view, which corresponds to the Marxist approach to human activity and consciousness, the individual in a group or the small group as part of a larger social unit should actively work out their new position and the image of their life. It needs considerable inner effort to realize and to evaluate the emergent situation, to revise the formed motives and value orientations. Naturally this process takes place in the mind of each individual, but always in their interaction and communication in a group or a larger social community. Sometimes this process takes a covert form, that of an individual's internal conversation with themselves. But even in this case the individual remains in the context of social relations since it is simply impossible for him or her to get out of them.

This process cannot be properly understood with the help of such notions as adaptation and reinforcement. The term 'struggle' would be more appropriate here meaning not the struggle for a mere physical survival, but the struggle of a human being for his or her self-esteem as personality. The contents of this struggle depend on the nature of a social system, where the struggle goes on, and on the status that the individual or the group have in this system (in a class society - under the conditions of class struggle, in a socialist society - under the conditions of struggle for the people's common interests). If we want to research the psychology of social change, we cannot abstract ourselves from the concrete historical conditions. The program of social psychology should first and foremost take them into consideration.

Of course, objective social conditions alone do not explain all the problems of social psychology. It is important to designate the more concrete mechanisms that are to be researched. Take, for example, the nature of cognitive stereotypes. It is not 
yet clear how such a change is proceeding as the discredit of imaginary values imposed by the interests of a certain social group, and the search for new values. This problem is connected with other problems that are hardly researched (investigated), for instance, that of affective accumulations, which cannot be explained with reference to frustration or aggressiveness inferred from human nature. All these phenomena are brought about by social relations. They are symptoms, and not factors. For instance, conformism is also a symptom that may indicate different social psychological phenomena. And finally we think it is necessary to revise critically the role of the notion when referred to personality or to intragroup relations and especially when applied to the research of change.

We have mentioned only some problems here. Their number and complexity will no doubt increase as soon as we start the actual research. But we have to raise and solve these problems if we really want social psychology to enjoy the status of a mature scientific discipline.

\title{
References
}

Israel, J., \& Tajfel, H. (Eds.). (1972). The context of social psychology: a critical assessment. London: Academic Press.

Toffler, A. (1970). Future-shock. London: Random House.

Andreeva Galina Mikhailovna (1924-2014) - Doctor of Philosophy, Professor, Honored Scientist of the Russian Federation, Full Member of the Russian Academy of Education, the founder and long-term Head of the Department of Social Psychology at Moscow State Lomonosov University (1972-1989).

Leontiev Alexey Nikolaevich (1903-1979) - Doctor of Psychology, Professor, Full Member of the Russian Academy of Education, the founder and permanent dean of the Faculty of Psychology, Moscow State Lomonosov University (1966-1979).

\section{Методические проблемы исследования психологических аспектов социальных изменений}

\author{
Г.М. Андреева ${ }^{\mathrm{a}}$, А.Н. Леонтьев
}

${ }^{a}$ работал(а) в МГУ им. М.В. Ломоносова

\section{Резюме}

В статье представлена концепция социальных изменений в рамках социальной психологии. Существует три уровня социальных изменений: (1) Радикальные преобразования типа социальных отношений и экономической формации посредством 
социальных революций. (2) Происходящие на системном уровне изменения конкретных областей общественной деятельности, таких как образование, массовая коммуникация и т.д. (3) Изменения, влияющие на жизнедеятельность малых групп или отдельных лиц. Психологический аспект социальных изменений (особенно на двух верхних уровнях) ограничен изучением восприятия человеком этих изменений, что сужает рамки компетенции психологии при изучении макроизменений. При этом третий уровень социальных изменений входит в область социальной и, кстати, общей психологии. Специфика психологических исследований социальных изменений на разных уровнях связана с различными уровнями методологии: от общих философских основ до специальных методов исследования. Роль разных уровней методологии варьируется в зависимости от уровня социальных изменений. Вопрос о сопротивлении изменениям также требует особого рассмотрения, определяемого уровнем анализа. Также обсуждаются возможности и ограничения экспериментальной стратегии исследований. Отсутствие признания более широкого социального контекста определяется как слабость современной социальной психологии, которой необходимо уделить внимание. Исследование изменений способно приблизить социальную психологию к жизненным проблемам, поскольку человеческая ситуация в целом всегда является социальной и меняющейся. Перед лицом перемен человек вовлечен во внутренний диалог или во внутреннюю борьбу с целью адаптации к изменениям, сохраняя при этом личную самооценку.

Ключевые слова: социальные изменения, уровни методологии, сопротивление изменениям, экспериментальная стратегия, социальный контекст, человеческая ситуация.

Андреева Галина Михайловна (1924-2014) - доктор философских наук, профессор, заслуженный деятель науки РФ, действительный член РАО, создатель и многолетний заведующий кафедрой социальной психологии МГУ имени М.В. Ломоносова (1972-1989).

Леонтьев Алексей Николаевич (1903-1979) - доктор психологических наук, профессор, действительный член РАО, создатель и бессменный декан факультета психологии МГУ имени М.В. Ломоносова (1966-1979). 


\section{INTRODUCTORY WORDS TO A.N. Poddiakov, N.N. Poddiakov. Interactive Exploratory Objects: From Laboratory Experiments to Mass Practices of the XXI Century}

The role of curiosity, exploration and experimentation in cognitive development (as was first experimentally studied by Jean Piaget), is now universally acknowledged. In order to better explore curiosity, exploration and experimentation, as well as maintain and develop them, we need specially developed cultural tools, including specially designed exploratory objects. Their inventor sets themselves a task of ensuring that another person when faced with them, will display exploratory activity and acquire this or that information (in the limit - as diverse as possible) in the process of independent cognition. Then exploratory activity, intellect and creativity interact as a whole and the results of cognition are determined by the harmony of this interaction.

At the same time, the diversity of exploratory objects invented by people for the purposes of play, education, and testing, as well as the history of their development and current trends in this area, usually do not become the subject of special consideration. The paper aims to change this situation. Both authors have considerable experience in developing objects for investigating exploratory behavior. The one who has written these introductory words also has a certain experience of being examined as a participant in psychological experiments conducted by the other author of the paper and by his colleagues (judging by the photo taken at one of the first experiments, on a completely voluntary basis).

One of the main points of the paper is as follows: if a developer of the items for IQ tests may not be concerned with these items being of interest for the participant

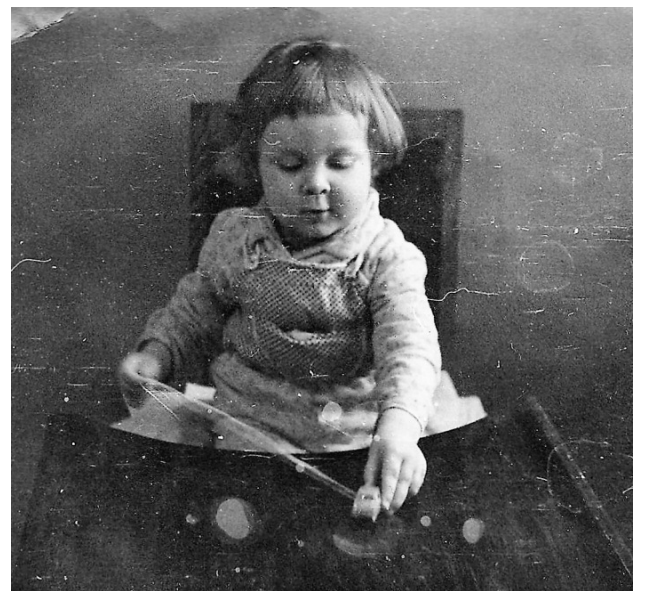
(the participant's interest may be here, metaphorically speaking, as the icing on the cake), then the developer of an exploratory object must ensure that it will stir interest. The authors of the paper are aware that in a certain sense this also applies to texts about exploratory objects. This can never be guaranteed in advance, but the authors have tried their best to have it, at least, not akin to counter-exploratory objects like Jack-in-the-Box types of toys. 


\title{
INTERACTIVE EXPLORATORY OBJECTS: FROM LABORATORY EXPERIMENTS TO MASS PRACTICES OF THE XXI CENTURY
}

\author{
A.N. PODDIAKOV ${ }^{\mathrm{a}, \mathrm{b}}$, N.N. PODDIAKOV
}

\begin{abstract}
${ }^{a}$ National Research University Higher School of Economics, 20 Myasnitskaya Str., Moscow, 101000, Russian Federation

${ }^{b}$ Institute of Psychology, Russian Academy of Sciences, 13 build. 1, Yaroslavskaya Str., Moscow, 129366, Russian Federation
\end{abstract}

\begin{abstract}
The paper is focused on the history and modern practices of creating and applying interactive exploratory objects and worlds that provoke curiosity in the individual and require exploration and experimentation to learn them and to achieve practical goals. The development, use and demonstration of a wide range of exploratory objects (play, educational, psycho-diagnostic, etc.) in various fields reflects an increasingly wide spread belief: one of the basic human abilities that is needed now and will be in demand in the future is the ability to cope with novelty, including through active exploration and experimentation. Five interrelated directions for the development and popularization of exploratory objects are identified: science; educational practice; assessment; game practices; and literature, art, official and unofficial journalism. Parameters of specially developed interactive exploratory objects and worlds in the context of preparing for encounters with novelty and complexity are discussed. The triangle of tests of intelligence, creativity and exploratory behavior in the space of regulation - freedom is presented. Two types of motivational challenges when exploring new objects are described: exploration for the sake of the very process of cognition and exploration for the sake of desired practical effects. The issue of features of exploratory objects that stimulate posing and solving epistemic problems rather than pragmatic problems, and vice versa, is raised. In conclusion, possible reasons for the mass development and supply of exploratory objects and worlds are formulated.
\end{abstract}

Keywords: interactive exploratory objects, experimentation, exploratory behavior, intelligence, creativity, education, games.

At present, there is a great interest in culture in the study of novelty - novel objects, situations, and worlds. There are films emerging where the protagonist is an astronaut on a different planet alone fighting for survival, and one of the ways to struggle for life is the exploration of the external environment and the possibilities of materials, tools and instruments brought from Earth and their creative use. Varieties of quests are extremely popular with both adolescents and adults who pay

This paper was prepared with the support from the Russian Science Foundation, Grant \# 17-78-30035. 
money, for example, to be locked alone or in a small group in a room with various incomprehensible objects, stashes, ciphers, etc., to solve all mysteries and get out during a set period of time.

The number of toys for children is intensively growing that function to develop the child's thinking during exploration and experimentation (this is what is explicitly written in the instructions). These are a special class of toys (they are neither dolls, nor little cars, nor little cups and saucers, etc.). They do not have a clearly identified practical function, but they look like diverse attractive little boxes with buttons, windows, light panels, hidden speakers, moving elements, etc. When the child presses a button or turns a handle, a window is lit and a funny image appears; when another button is pressed a nice whistle sounds; when you press the third button, a niche opens and there is something interesting inside that was not visible before, etc. In terms of cybernetics, such toys are 'black boxes' with unknown content, and now they are en masse offered to preschoolers for instructionless exploration and learning.

Computer games that imply exploration, experimentation and problem-solving are quite popular: those are advanced adventure games for amateurs, and less complex investigational logic puzzles offered immediately to a huge number of Internet users. Some interactive Google Doodles can be an important and illustrative example of such games created for a worldwide audience. Considering the significance of the received response, we should start with Google Doodle that was dedicated to the 60th anniversary of Stanislaw Lem's first publication'. It is hardly possible to name another writer (a sci-fi author and a philosopher) who has equally contributed to the explanation and popularization of the topic of exploring various black boxes of natural and artificial origin, like Lem. Accordingly, Google users were offered to experiment with amusing black boxes of increasing complexity, and this Google Doodle became the subject of publication in the Daily Mail, The Guardian, The Telegraph ${ }^{2}$, etc. It is also worth mentioning the recent Google Doodle, which requires experimenting with the range of catapult throws of garden gnomes figurines; the properties of their flight are initially not obvious ${ }^{3}$; etc. In all these Google Doodles the user is not given any instructions - they must understand on their own, through exploration and experimentation, the way virtual objects work.

Moreover, experimenting with a new technical object (device) without preliminary briefing ("Just experiment and see how it works") becomes an important aspect of mass diagnostics of 21st century skills. We can use as an example interactive items designed for the Program for International Student Assessment (PISA).

\footnotetext{
${ }^{1}$ https://www.google.com/doodles/60th-anniversary-of-stanislaw-lems-first-publication

${ }^{2}$ http://www.dailymail.co.uk/sciencetech/article-2065103/Stanislaw-Lem-Google-DoodleI n t e r a c tive - a n i mation-celebrates-s c i-fi-gen i u s-work. htm l https://www.theguardian.com/technology/2011/nov/23/google-doodle-stanislaw-lem-anniversary, https://www.telegraph.co.uk/technology/google/google-doodle/8908900/Stanislaw-Lem-60thanniversary-of-first-book-celebrated-with-giant-robot-Google-Doodle.html

${ }^{3}$ https://www.google.com/doodles/celebrating-garden-gnomes?hl=en
} 
The Program involves hundreds of thousands of 15-16-year-old schoolchildren from dozens of countries. In 2012, for the first time in the history of mass testing and evaluation, the participants proposed a new type of tasks (for international mass testing rather than for scientific psychology or for Google users) - interactive assignments. For example, while clicking on the buttons of a virtual MP3 player (that doesn't have a manual provided) and observing the reactions, the participant had to understand the operating principle and then perform tasks that assess understanding of this principle (OECD, 2013, 2017). Another task of the same type is called Climate Control (experimenting with another device - air conditioning $)^{4}$. Directions to assignments of this type often paradoxically begin with the words: "You have no instructions for your new device. You need to figure out how it works (how to use it)."

The explicit or implicit premise ("there are no instructions for the new object so it needs to be explored") seems to be a philosophically loaded feature and the key characteristic for the development of all the above examples, rather than numerous problem-solving situations created by some people for others. The main component of these situations is the presence of exploratory objects (or whole worlds) that are designed on the principle of black boxes of varying complexity and blackness (opacity) - they need to be explored and experimented with, their non-obvious, hidden properties are to be identified, and connections for their understanding and the successful achievement of those or other purposes should be located. In a sense, given the growing scale, this is a new civilizational situation.

In general, at least five interrelated directions for developing exploratory objects can be identified.

1. Science - the exploration of the means by which different people (children, adults, beginners, experts, etc.) cope with novel objects and (micro) worlds, their motivations, cognitive strategies used, the effect of different features of these objects on motivation, the parameters of strategies, etc.

2. Educational practice - the inclusion of exploratory objects and worlds in learning and development programs.

3. Evaluation - an assessment of the degree the assessed people have competence in exploring novel objects and worlds.

4. Game practice - the development and production of exploratory toys for children and adventure games with a pronounced research component for people of all ages (if only they were interested).

5. Literature, art, official and unofficial journalism - here exploratory objects and worlds are represented as 'human displays' in the understanding introduced by Gibson (1979, p. 42). Human displays are sculptures, paintings, photographs, films and animated cartoons, written texts, etc. Being specially created for other people all these objects, "mediate or indirect, knowledge at second hand" (Ibid.). For our part, we will give examples of specially created 'human displays' that represent for other people mediated or indirect knowledge about exploration, experimentation, their possible objects, predictable and unpredictable effects. Those include:

\footnotetext{
${ }^{4}$ http://www.oecd.org/pisa/test-2012/testquestions/question3/
} 
- a scene in a science fiction feature film of an astronaut experimenting with an artifact from another civilization on another planet;

- a scene in the animated film by Zdeněk Miler of the Little Mole experimenting with a radio receiver (the character had never seen radios before);

- a description of the young Moomins experiment with the Magician's Hat (that was black, of course, like the 'black box') in the fairy tale of the same name by Tove Jansson;

- a description in an Internet publication of a person who tried to work out the mechanism of a tap or an air conditioner of an unknown model in a hotel abroad;

- Youtube videos posted for mass viewing that show how children react to a jack-in-the-box ${ }^{5}$, etc.

We are talking about the relationship of these five aspects that can be most easily explained in the above example of Google Doodle dedicated to the 60th anniversary of Stanislaw Lem's first publication. Lem's written texts (the Cyberiad cycle) became an incentive for the Google computer company to create an interactive computer toy, which in turn works as a source of direct exploratory experience for the player and a source of observation for her or his younger sibling or a desk mate at school; it may be a topic for discussion in private Internet blogs and the subject of reports in the Daily Mail, The Guardian, The Telegraph, etc., as well as an example of a research object in the paper you are reading. However, as will be shown below, the network of interconnections between aspects of the development of exploratory objects is not limited to this example - it is much broader.

\section{A brief history of the development of exploratory objects}

In human culture, puzzles - toys that can be understood through experimentation, have been known for a long time: at least since the Middle Ages. These are different puzzle boxes that cannot be opened if you don't know the secret; puzzle mugs with hidden holes and canals inside the walls designed not so much for drinking as for pouring the liquid all over the drinker (if they cannot figure out by researching how to hold it and which holes to press their fingers against).

Scientific research and diagnostics of exploratory behavior with the help of specially designed objects began in the second half of the 20th century. Although the history of the study of exploratory behavior begins with the work of I. P. Pavlov on orienting reflexes and orienting-exploratory reactions, afterwards, until the 1950s, the studies mainly focused on the reactivity of animals and humans. Often they were conducted using Skinner boxes in which the animal had to find an operational means by using a key or bar in order to get food or other reinforcement. The value of one's own free cognitive activity guided by curiosity and manifested in independent

\footnotetext{
${ }^{5}$ https://www.youtube.com/watch?v=WWxUkzOJX58. Different versions of the jack-in-thebox (toys designed to have an object unexpectedly jumping out that is (un)attractive, for example, a little devil, during the investigation) can act not only as exploratory objects, but also as counterexploratory objects; see in (Poddiakov A., 2017) on this opposition.
} 
exploratory behavior was realized and recognized later. If behaviorists were rather interested in reactivity (the stimulus-response scheme), the new paradigm opposed this, for it became a paradigm of free activity, including exploration, in a complex environment.

In this paradigm, the ideal of an experimental object (offered to the participant to perform independent cognitive activity) is an object with an infinitely large number of different-level hidden elements, properties and connections - from those that can be easily identified and are almost obvious, to those extremely difficult to detect and understand. At the extremes of activity modeled in such an experiment is the intrinsically motivated cognition by a subject of a complex, diverse world that gradually unfolds at emerging levels (Poddiakov A., 2012). The person here (unlike demonstrating reactions with the Skinner box) can set increasingly complex epistemic and practical goals and apply different strategies. Accounting for the diversity of goals and strategies is a fundamental feature of the study of curiosity and exploratory behavior, in contrast to the study of behavior based on Skinner boxes, where the learning curve is always assumed to be fundamentally the same not only for different individuals, but for different species (it may differ only in the degree of steepness-flatness).

Participants in the experiments on studying curiosity and exploration are offered specific specially designed exploratory objects and environments of varying complexity that allow the realization of the principle of the developing cognitive intrigue and thereby induce the participant to actively forecast, hypothesise, explore and experiment (Poddiakov N., 2011, 2012).

As an example of an exploratory object (which was new and rather complex for children) used in psychological experiments in the late 1950s, we should describe a device developed by one of the authors of this paper, N. Poddiakov, who at that time was a post-graduate student of A. Zaporozhets. (In the 1920s-30s, Alexander Zaporozhets was a student and colleague of Lev Vygotsky, and in the 1950s he organized his own direction in studying the research activities of children.)

The experiments of $\mathrm{N}$. Poddiakov became one of the first (or, probably, the first) research where preschool children were offered to independently explore new objects with rather complex hidden connections that required detailed experimentation (Poddiakov N., 1959, 1960, 1977; Poddjakow, 1981). (We will be grateful if earlier analogues could be indicated; the study of the children' orienting activity aimed at the establishment of connections between buttons and bulbs that would light on a stand, had different versions before, but it seems that there has been no studies of experimentation and searching for ways to remotely control a new dynamic object). For example, a child of 5 y. o. was offered an object with four buttons that controlled the movement of a doll (a toy boy) on the working field (Figure 1). When one or another of the four buttons were pressed, the doll could move in one of four directions - to the participant (who was behind the control panel), away from the participant, to the right and to the left. By alternately pressing the buttons of the remote control, it was possible to bring the doll to any point of the experimental field, and to make it circle it around any obstacle placed in its path. By experimenting with the buttons (they did not have any information on 
The device for study of children's experimentation (Poddiakov N., 1977; Poddjakow, 1981)

- - buttons that have originally unknown functions

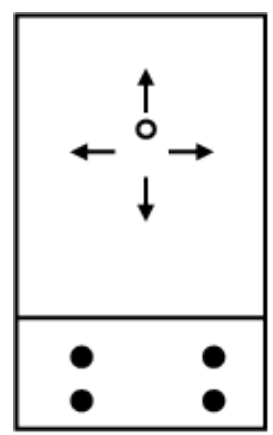

them) the child had to understand how the device worked, how to guide the boy through the labyrinth of various complexity, etc.

Now, in an era when practically every household device is equipped with buttons with arrows $\leftarrow, \rightarrow, \uparrow, \downarrow$, this exploratory object and the principle of controlling it seem simple, but in the 1950s, when it had been developed and applied in psychological experimentation, these types of remotely controlled toys were a much rarer phenomenon than now, and did not seem to be used at all in psychological experiments to study the exploratory behavior and thinking of preschool children. In order to have an approximate understanding of the nature of the preschooler's activity in the 1950s who would sit behind this experimental setup, you may imagine that you have a remote control for a vacuum cleaner without any signs on the buttons. Besides, you do not know what a vacuum cleaner is. Perhaps during the survey of this object you will have a normative idea formed of the object and its function, but perhaps you will find another (unexpected and creative) use for it.

A number of experimental schemas for studying thinking using such objects were also designed (Poddiakov N., 1977; Poddjakow, 1981). First of all, they include, for example, alterations in the structure of hidden links that a child wouldn't expect in an object that they seem to have already studied: the buttons of an object changed their functions at some point - functions of a button would be performed by another one (for example, the button that moved the doll to the left, would begin to move it forward; the button that used to move it forward would have changed to moving the doll to the right, etc.). This caused astonishment in children and new cycles of experimentation with a seemingly well-known, identically looking, but inwardly substantially changed, 'reprogrammed' object that could not be controlled then in the same way as the child had learnt before, and it was necessary to understand what to do then. In the late 1950s with the use of this object important differences were found in the child's experimenting exploratory actions aimed at establishing causal links in the object: from the performance aimed at directly solving a practical task (for example, to direct the doll to go between the placed barriers from one end of the field to the other). The readiness of children for 
transitions from direct experiment to experiment when the button functions changed (in a 'turbulence mode' of the object and activity) and back (from experiment to direct experiment and even automated acts) when the 'updated', reset button functions were fully understood by the participant, and the need for the samples would disappear (in a 'stability mode').

In the 1960s the number of exploratory objects invented by researchers and used in experiments was growing as was the diversity of the goals of these experiments. Keller gives images of some exploratory objects for children of different ages (Keller, 1994). First of all, this is a Hutt-box (for children from 2 years old), perhaps, at some point it was one of the most famous exploratory objects. It was developed by C. Hutt and enabled the operationalization of the differences between the specific and diversive exploration in Berlyne's terms, or between exploration and play in Hutt's terms (Hutt \& Bhavnani, 1972). The very sequence of images of these objects shows some aspects of their complication to match the age characteristics of the participants.

At present, one of essential trends (in terms of the transition from laboratory experiments to mass practices) is the development of exploratory objects that can be understood not only by children (if the participants are children) but also by parents in terms of the functions of these objects in the cognitive development of children, and which additionally stimulate parents to independently examine and develop their children's exploration and play, to find new exploratory objects for their children, etc. One example is what the Discovery Center's Living Laboratory offers to the visitors of the Museum of Science (Boston, USA) ${ }^{6}$. Developmental psychologists from different scientific centers cooperate with the laboratory. One of the important directions here is the study and popularization of learning through play ${ }^{7}$. At the Living Laboratory website parents can read short understandable notes 'How does expectation affect exploration?', 'Do children prefer to explore toys that provide clear evidence?', 'Do children play more when evidence is not clear?', etc. After reading the description of a scientific experiment where children experiment with an interesting exploratory toy, and having seen the attractive images, parents also read the suggestions and invitations: "Find a toy in your home that has many buttons or levers that your child can investigate. Does your child take time to push one button or lever down at a time to find out how it works? How long will your child play with one toy before moving on to a new one?"10, etc. This is one of the manifestations of the transition from laboratory experiments to mass practices. Any parent on the planet who uses the Internet, after reading these descriptions and invitations, can take an exploratory position in relation to exploratory behavior and experiment with exploratory objects of their child.

\footnotetext{
${ }^{6}$ https://www.mos.org/living-laboratory, http://legacy.mos.org/discoverycenter/livinglab

${ }^{7}$ http://legacy.mos.org/discoverycenter/livinglab/ltp/list

${ }^{8}$ http://legacy.mos.org/discoverycenter/livinglab/ltp/phonesthemes

${ }^{9}$ http://legacy.mos.org/discoverycenter/livinglab/ltp/popbeads

${ }^{10}$ https://www.mos.org/living-laboratory/explore-our-research/jack-in-the-box
} 
Another example of the popularization is that developers of interactive tasks for PISA 2012 (that are offered to tens of thousands of schoolchildren and require exploration and experimentation with new objects), indicate that these tasks are based on the complex problem solving approach (OECD, 2013, 2017). In the 1970s the approach was launched with the laboratory experiments of D. Dörner (1997). We can also make an informed assumption that the Tanaland, Moro, and Lohhausen scenarios developed then by Dörner for laboratory research of thinking, were the forerunner of many modern strategic computer games such as SimCity, Civilization, etc. (Poddiakov A., 2012; Riegler, 1998).

Throughout the history of scientific studies of curiosity and exploration, the developers have created exploratory objects and worlds to identify psychological phenomena and patterns in two related areas - motivation and cognitive strategies (e.g., strategies of causal inferences) (Bonawitz et al., 2011; Buchsbaum, Gopnik, Griffiths, \& Shafto, 2011; Chase \& Klahr, 2017; Cook, Goodman, \& Schulz, 2011; Dean \& Kuhn, 2007; Dörner \& Funke, 2017; Ford, 2005; Forman, 1986; Funke, 2014; Greiff, Molnár, Martin, Zimmermann, \& Csapy, 2018; Jirout \& Klahr, 2012; Klahr \& Dunbar, 1988; Poddiakov A., 1992, 2011; Poddiakov N., 1959, 2011, 2012; Schauble, 1990; Schulz \& Bonawitz, 2007).

Computer technology plays an increasingly important role here. In the mid1980s experiments had been started where children and adults were asked to experiment with robots, computerized systems such as LEGO and computer microworlds; besides, computerized exploratory objects and worlds came into use in teaching scientific inquiry. An important modern trend associated with the development of technology is the development of virtual exploratory objects and worlds that allow:

- the creation of computerized interactive collaborative problems for collaborative exploratory activities of several participants based on the principle of jigsaw problem: none of the participants have complete information about the task and a sufficient set of solutions; the information and material resources of all participants vary, and the research task can be solved only by negotiating, exchanging information, and combining the possibilities (Graesser, Kuo, \& Liao, 2017; OECD, 2013, 2017);

- the collection of big data and use of data mining on the research strategies of a large number of users (Greiff, Niepel, Scherer, \& Martin, 2016);

- the study of a participant's brain activity during the survey of new worlds and the relevant objects (certainly so far on small samples in laboratory settings) (Fields, 2016; Snider, Plank, Lynch, Halgren, \& Poizner, 2013).

\section{Tests of intelligence, creativity and exploratory behavior in the space of regulation - freedom}

It is probably no coincidence that in the same historical period (1950-60s), the animated film The Mole and the Car by Zdeněk Miler was shot (where one of the key episodes is how the Little Mole examines a parking lot and a car), and Tove Jansson wrote The Exploits of Moominpappa (Moominpappa's memoirs) where 
there is a wonderful piece about Daddy Jones's garden, a specially created exploratory, adventure environment where characters explore and find something at their own will and understanding, and then, unexpectedly for them, according to the results of these searches, they are rewarded and receive information about their individual characteristics (!). And it is no coincidence that at that time the first scientific psychological studies of independent exploratory behavior began to unfold opposing the behaviorist study of behavior in Skinner boxes. The period of the 1950-60s was a new socio-cultural situation, and the concepts of novelty and freedom, and free choice in a new environment should be used as key concepts to describe it. (The new youth movements of the 1960s, hippies, rock music, the movement of radio amateurs who would invent the first and so far unprecedented electronic video games, etc., etc., can also largely be described by these concepts.)

We shall turn to the tests. Such freedom, as in the tests of exploratory behavior, had not always been provided to participants, but also became a reality from the 1950-60s.

Historically, the first tests of intelligence appeared at the turn of the 19-20 centuries. They measure a person's ability to quickly solve a large number of problems from a proposed set during a limited time. The tasks are already clearly formulated by someone, they have a known way of solving and the answer, which is considered to be the only correct one. In the 1930s tests of a new type were developed to overcome the one-sidedness of intelligence tests - tests of creativity. They use openended tasks, that is, they have not one single right answer, but presuppose the possibility of multiple answers (in the limit, infinite).

These tasks are designed to induce a person to invent new, diverse, original solutions to the problem posed by another person (developer). For example, you need to come up with as many ways of unusual use of the seemingly most common object (like a pencil, a brick, etc.), to invent as many improvements as possible of a toy, etc. Tests of exploratory behavior emerged in the 1960s that allowed the study of aspects of cognitive activity that were not covered by tests of intelligence/creativity. Tests of exploratory behavior diagnose a person's ability to acquire new information in real interaction with new unknown objects, to act practically in conditions of novelty and uncertainty, while independently setting and solving various exploratory (inquiry) tasks.

We shall emphasize this fundamentally important aspect. Although problem posing is considered an important part of learning and thinking in some educational approaches (Brown \& Walter, 2004; Mishra \& Iyer, 2015), it is difficult to find psycho-diagnostic tests that would assess a person's ability to pose problems and come up with tasks, rather than just to solve problems posed by someone else. Tests of exploratory behavior provide such an opportunity.

The most universal tests of exploratory behavior can be described as problematic situations that have both an open end and an open beginning. The open beginning means that here (in contrast to the tests of intelligence and creativity tests) the participant themselves poses problems and "asks questions" to the object, poses tasks and solves them, constantly collecting and defining information about all emerging properties of the object and conditions of achieving the goals. Tests of 
exploratory behavior enable both the freedom of answers and the freedom of questions. On the one hand, this is the freedom of questions to the object or the system (What are you, what is the way you are arranged, how will you react if I do this? And what if I do that?, etc.). On the other hand, these are new degrees of freedom that are related to other people's questions: questions to the experimenter, as well as questions to joint survey partners when it comes to the interactive collaborative problem situation: What do you see? How did the object react when I did this? What can we think of in order to learn this better?, etc.

Does this mean that, for example, there is absolutely no freedom in intelligence tests? There is freedom, the freedom to find a solution that was conceived by the developer and is unknown to the subject. But there is no freedom for an independent statement of a problem or a question.

Accordingly, we can offer a 'triangle of types of test problems.' This is a graphic model of the relationship between the tasks of tests of intelligence, creativity and exploratory behavior and various real problems in the space of regulation - freedom (Figures 2, 3).

We should understand that although tests of exploratory behavior increase degrees of freedom, freedom is not as ultimate as in creativity tests, where the flight of imagination can be almost unrestrained (you can finish a proposed figure as you like, just be original, different from other participants). And when a real object is explored, physical limitations of the real world come into play. Some things in the real world cannot be done (for example, clearly you cannot make a perpetual motion machine and a research instrument based on it). Therefore, in the proposed triangle of tests, the freedom of answers in tests of exploratory behavior is lower than in tests of creativity, although higher than in intelligence tests.

Inside this triangle of tests various cognitive tasks can be placed that exist in real life, according to the extent to which they are loaded with an exploratory component

The triangle of tests of intelligence, creativity and exploratory behavior in the space of regulation - freedom

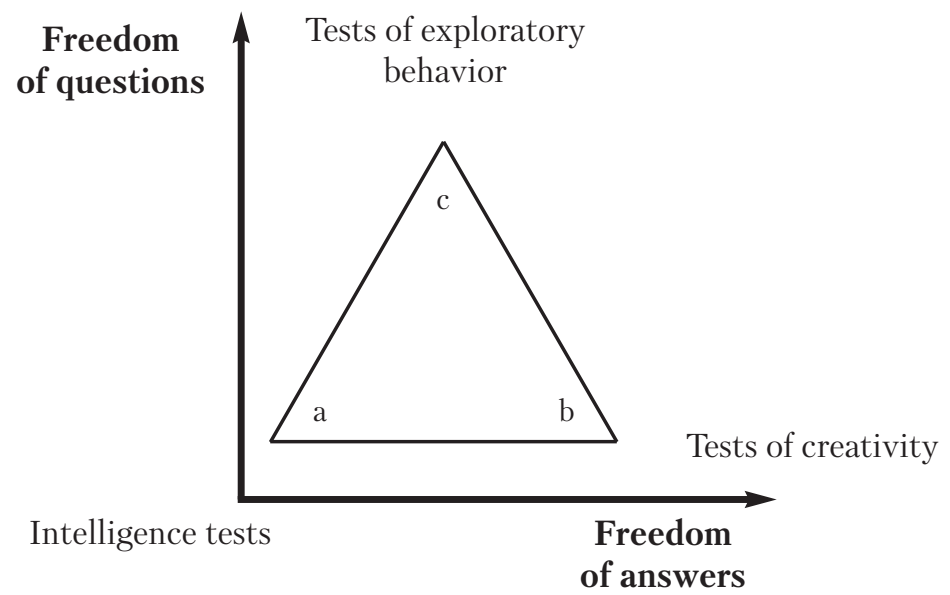


The variety of real problems in the contour of the 'triangle of tests' of intelligence, creativity and exploratory behavior

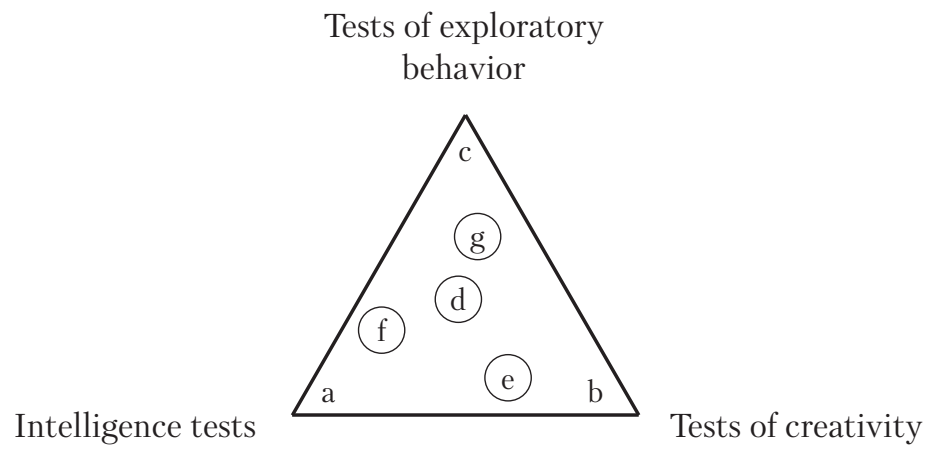

a - tasks that predominantly require intelligence as it is understood in tests;

$\mathrm{b}$ - tasks that predominantly require creativity as it is understood in tests;

c - tasks that predominantly require exploratory behavior as it is understood in tests;

$\mathrm{d}$ - mixed tasks that require both exploratory behavior, creativity and intelligence in an approximately equal proportion;

$\mathrm{e}$ - mixed tasks that predominantly require creativity and intelligence and to a lesser extent, exploratory behavior;

$\mathrm{f}$ - mixed tasks that predominantly require intelligence, less exploratory behavior and, to an even lesser extent, creativity;

$\mathrm{g}$ - mixed tasks that predominantly require exploratory behavior and, to a lesser extent, creativity and intelligence as they are understood in tests.

(the potential and the need to observe and practically experiment with objects and systems while getting emerging information about their properties, connections, etc.), a creative component (the ability and necessity to generate multiple original solutions) and an intelligent component in the test sense (the necessity to seek accurate answers to questions clearly posed by someone). Such a triangle, without claiming to provide an exhaustive picture of cognitive activity, enables the evaluation of certain real life and professional cognitive tasks in regard to the proportion of various important components in them (Figure 3).

Thus, throughout the 20th century, a trend in the development of testing cognitive abilities can be seen that stretches from the maximum regulation of the subjects' activity (when solving tasks clearly formulated by the developer that have the only correct answer) to diagnostic problematic situations of high novelty and uncertainty that have open beginnings and open ends and imply the use of special exploratory objects and worlds to design and develop them. And these exploratory objects and worlds are of great interest. This is natural. After all, the developer's task is to create an exploratory object that is meta-affordance, an opportunity 
offered to another person to satisfy their cognitive motivation and motivation in the new system (Poddiakov A., 2017). Let us focus here again on IQ tests. Their developers in the beginning of the 20th century did not aim to make the tasks interesting for the participant (they could be interesting for some participants, but not due to the specially set goal of the developer, but rather due to the individual characteristics of certain participants). With the tests of creativity and, especially, of exploratory behavior, the situation is different as the participants' cognitive interest is of importance here, so that they could take advantage of the freedom they are given; the need to develop the participant's personal cognitive interest is taken into account when developing test objects. If a participant is not interested in a task in an IQ test, this does not really bother the test developer. If the participant is not interested in a task of a creative thinking test or a test of curiosity and exploratory behavior, we call it a professional failure of the developer.

\section{Two types of challenges when exploring new objects}

When a person explores new objects, two types of challenges can be identified that affect the specifics of cognitive strategies. One of the challenges is to understand a new and complex object as such, irrelevant to possible utilitarian and practical results. Here cognitive strategies are directed by curiosity and the need to obtain new information and new knowledge. Getting knowledge here is 'disinterested,' it happens for the sake of the very process of cognition (Poddiakov N., 1977; Poddjakow, 1981).

The other type of challenge is to make the new and complex object function in the desired way, to elicit from it the necessary practical effects (for example, to force a new device to work in a desired mode). This is possible only on the basis of the preliminary examination and understanding the object, but here other cognitive strategies for the problem of posing and problem solving are deployed (Ibid.). The real process of cognition is maintained in the close interaction of both types, and depending on the prevalence of one or the other type of challenges, the entire thinking process as a whole acquires a relevant tendency.

A similar distinction was introduced by Schauble (Schauble, Klopfer, \& Raghavan, 1991). The researchers write that students can implement in their exploratory activities either scientific or engineering models of experimentation, that is, they either seek to understand the internal cause-effect relationships within the object, or try to obtain from it a certain desirable practical outcome (for example, the maximum speed of a new virtual car). This difference in goals leads to varied research strategies and a focus on different sides of the object.

The authors point out that the difficulties in teaching the basics of scientific inquiry to students are associated not only with the way children construct logical reasoning, but also with the fact that they often confuse the purpose of scientific experimentation with the one of the engineering model. The engineering purpose is quite appropriate, but it interferes with understanding the object in its completeness and variety of cause-effect relationships, which is not very good when teaching scientific inquiry. It is important that students should understand the differences between these goals. 
Can these or other exploratory objects intrinsically instigate a more rather disinterested exploration and experimentation motivated only by curiosity, than pragmatic research related to practical problems, and vice versa: can various exploratory objects provoke in relation to themselves more pragmatic exploration and experimentation, rather than unselfish, non-utilitarian study?

In this respect the Henderson and Moore study is important where a distinction is made between free exploration and problem-solving exploration, as well as between novel perceptual toys and problem-solving toys. Free exploration of novel perceptual toys is not aimed at finding any certain correct solutions and actions. This is a study motivated only by curiosity. Problem-solving exploration of problem-solving toys is directed by a problem (for example, to get a doll out of a narrow box) (Henderson \& Moore, 1980). However, here there is no focus on possible differences in epistemic challenges and problems (problems posed and solved, for example, in the scientific type of exploration and experimentation) and practical challenges and problems (in the engineering type of exploration and experimentation). Given these differences, one can talk not just about problem-solving exploration, but about its two different types associated with the epistemic and practical problems posed and solved by a person examining a new object. The question remains open about objects that stimulate rather posing and solving epistemic problems than pragmatic problems, and vice versa. We certainly understand that there are no absolute types in reality, and setting goals when faced with a novel object depends on the context and individual characteristics of the individual, but it seems important to assess the possible contribution of the object features to the type of challenge it stimulates.

\section{The reasons for the mass development and supply of exploratory objects and worlds}

The mass practice of developing and offering to people newer and more diverse exploratory objects and worlds has at least four reasons (and they are interrelated).

1. The intensive development, use and demonstration of a variety of exploratory objects in various fields (research, education, testing and evaluation, games, literature, art, official and unofficial journalism) is a reflection of an increasingly popular belief that one of the basic abilities of the person that is necessary at the present time and will be in demand in the future, is the ability to cope with novelty, including through their active exploration and experimentation. It is assumed that people should be specially prepared to encounter novelty, so specially developed novel interactive exploratory objects and worlds can be an effective means of specific preparation and implicit learning.

2. A new technological situation at the household level: in recent decades, the share of new components in even the household environment has increased so much that each of us regularly becomes an explorer of some 'black boxes,' should it be a water tap or an electrical appliance in a hotel of a design we have not known before (and other numerous constantly updated gadgets and different types of household appliances). Often there is no user's manual to them, but if there is, it 
may cover not all necessary information, nor for all situations, and it is not always in the native language of a user.

Then the lacking knowledge has to be gained through all sorts of explorations and experimentation, by checking the functions of the controls (buttons, handles, etc.) in different combinations, by observing the varying modes of operation of the device, etc. (Moreover, quite a lot of users prefer to learn new devices specifically this way, by independent research, and they refer to manuals only in the last resort.) Only 100-200 years ago, there was simply no such mass exploratory activity at the household level, there were no relatively complex devices available to an individual, or, moreover, their constant updates, on a mass scale. Only 50-100 years ago did people start to get involved in experimenting with emerging objects of the environment and everyday life, and this became an important area of competence.

3. The role of science is growing, and the popularization of academic achievements in various fields (physics, chemistry, biology, neurosciences, etc.) is often designed as a narrative: people did not know about a phenomenon or did not understand its causes until a certain scientist thought about it, invented a tool and a method to investigate it, and used them to identify previously unknown, hidden essential properties and connections of the studied objects, and subsequently the world has changed (a disease disappeared, new technology emerged, etc.). This narrative of the history of scientific success can be strengthened by the addition of a brief but impressive history of previous failures (for example, the death of scientists during experiments as they did not understand either the essence of the phenomenon being studied, or some important details). Such narratives translate the idea of exploration of novelty as an important challenge that is both engaging and dangerous. This idea is harmoniously built into the growing number and variety of adventure games that attract by the opportunity of exploration, experimentation and serendipity of positive and negative results.

4. Targeted activity of the stakeholders (psychologists, educators, IT-visionaries, etc.) who believe their mission is the development of the exploratory potential in people and who develop new exploratory objects and worlds that show their importance. Originally, around the 1950-60s psychologists in different countries began to understand and formulate the value of exploratory behavior and experimentation with novel objects and to design suitable experimental objects to study them. It can be said that psychologists performed the experimentation of the 'second order': they experimented with the experimenting activity of children and adults while constructing new and more complex objects and systems, new conditions and procedures for their use, and based on the obtained data, they built their models and theories of cognitive activity.

Thanks to this experimentation with experimentation (continuing to the present), researchers get new facts and change their concepts of the laws of cognitive activity and its development, as well as ways to manage this development. Exploratory achievements in the field of these 'experiments with experimentation' are delivered to the public consciousness through a communication system. These 
are the websites of the Discovery Center's Living Laboratory in the Museum of Science and the publications of leading scientists on exploratory behavior in the journals Nature, Science, Scientific American, Scientific American Mind (Fields, 2016; Hutt \& Bhavnani, 1972; Gopnik, 2010, 2012; Klahr, Zimmerman, \& Jirout, 2011).

One of the key conditions for the proliferation of the development and supply of new and more diverse exploratory objects and worlds is again the development of technologies (first of all, computer technology and media). We shall remind about interactive Google Doodles that are available to users around the world and are covered in key global media. Other examples include the development of a virtual puzzle-box (or even a world model) by a programmer over a day (a week or a month) that is uploaded in the Internet and actively explored and discussed by users; the development of virtual scientific laboratories for schoolchildren by specialists in the field of education and IT; etc.

The community reacts to all this by changing the social order, supporting research and practical development of new diagnostic, didactic, gaming exploratory objects, worlds, and activities; the spiral of development is spinning even farther (Poddiakov A., 2012); in chemistry, this is called an autocatalytic process.

\section{Conclusion}

Preparing for an encounter with novelty and complexity is one of the main challenges within modern education, and the constant meetings with novelty and complexity are a challenge of modern life. The developmental effect of these encounters (educational and real life encounters in the broad sense of the word) can be expressed by a qualitative mathematical formula (Poddiakov A., 2014). It reflects the difference between the novelty and complexity of problems that a person (society, civilization) can set and solve before and after formal and informal events, educational processes, interactions that either stimulate or delay the development:

$$
E=N^{\prime} C^{\prime}-N C
$$

where $E$ is the developing effect of events and impacts, $N$ and $C$ are respectively, novelty and complexity of problems that a person (society, civilization) could set and solve before these events and interactions; $N^{\prime}$ and $C^{\prime}$ are respectively, the novelty and complexity of problems that a person (society, civilization) can pose and solve after these events and interactions.

An important means of preparing for meeting and working with novelty and complexity is the organization of collisions with specially designed exploratory objects and worlds. Will the mass development of these exploratory objects, worlds and activities continue to develop with an increasing speed, perhaps even more than now, or at some point (which is quite likely) will it slow down (like any mass trend) or even stop and go backwards? What could be the causes of this increasing acceleration, or, conversely, of inhibition and retreat? Developmental and cognitive 
psychologists who invent and design exploratory objects and worlds and read books by Stanislaw Lem, could think about it.

Incidentally, in addition to the actual cognitive interest, this can become the basis for an adventure game plot. Perhaps, in the beginning it will have to be tested in laboratory conditions.

\section{References}

Bonawitz, E., Shafto, P., Gweon, H., Goodman, N. D., Spelke, E., \& Schulz, L. (2011). The doubleedged sword of pedagogy: Instruction limits spontaneous exploration and discovery. Cognition, 120(3), 322-330. doi:10.1016/j.cognition.2010.10.001

Brown S. I., \& Walter, M. I. (2004). The art of problem posing (3rd ed.). New York: Routledge.

Buchsbaum, D., Gopnik, A., Griffiths, T. L., \& Shafto, P. (2011). Children's imitation of causal action sequences is influenced by statistical and pedagogical evidence. Cognition, 120(3), 331-340. doi:10.1016/j.cognition.2010.12.001

Chase, C. \& Klahr, D. (2017). Invention versus direct instruction: for some content, it's a tie. Journal of Science Education and Technology, 26(6), 582-596. doi:10.1007/s10956-017-9700-6

Cook, C., Goodman, N. D., \& Schulz, L. E. (2011). Where science starts: Spontaneous experiments in preschoolers' exploratory play. Cognition, 120(3), 341-349. doi:10.1016/j. cognition.2011.03.003

Dean, D., \& Kuhn, D. (2007). Direct instruction vs. discovery: the long view. Science Education, 91(3), 384-397. doi:10.1002/sce.20194

Dörner, D. (1997). The logic of failure: Recognizing and avoiding error in complex situations. New York: Basic Books.

Dörner, D., \& Funke, J. (2017). Complex problem solving: What it is and what it is not. Frontiers in Psychology, 8(1153), 1-11. doi:10.3389/fpsyg.2017.01153

Fields, R. D. (2016). Learning when no one is watching. Scientific American Mind, 27(5), 57-63.

Ford, M. J. (2005). The game, the pieces, and the players: generative resources from alternative portrayals of experimentation. The Journal of the Learning Sciences, 14(4), 449-487. doi:10.1207/s15327809jls1404_1

Forman, G. (1986). Observations of young children solving problems with computers and robots. Journal of Research in Childhood Education, 1(2), 60-74. doi:10.1080/02568548609594908

Funke, J. (2014). Analysis of minimal complex systems and complex problem solving require different forms of causal cognition. Frontiers in Psychology, 5(739), 1-3. doi:10.3389/fpsyg.2014.00739

Gibson, J. J. (1979). The ecological approach to visual perception. Boston: Houghton Mifflin.

Gopnik, A. (2010). How babies think. Scientific American, 303, 76-81. doi:10.1038/scientificamerican0710-76

Gopnik, A. (2012). Scientific thinking in young children: theoretical advances, empirical research, and policy implications. Science, 337(6102), 1623-1627. doi:10.1126/science.1223416

Graesser, A., Kuo, B.-C., \& Liao, C.-H. (2017). Complex problem solving in assessments of collaborative problem solving. Journal of Intelligence, 5(2), 10. doi:10.3390/jintelligence5020010

Greiff, S., Molnár, G., Martin, R., Zimmermann, J., \& Csapy, B. (2018). Students' exploration strategies in computer-simulated complex problem environments: A latent class approach. Computers and Education, 126, 248-263. doi:10.1016/j.compedu.2018.07.013

Greiff, S., Niepel, C., Scherer, R., \& Martin, R. (2016). Understanding students' performance in a computer-based assessment of complex problem solving: An analysis of behavioral data from computer-generated log files. Computers in Human Behavior, 61, 36-46. doi:10.1016/j.chb.2016.02.095 
Henderson, B., \& Moore, S. G. (1980). Children's responses to objects differing in novelty in relation to level of curiosity and adult behavior. Child Development, 51(2), 457-465. doi:10.2307/1129279

Hutt, C., \& Bhavnani, R. (1972). Predictions from play. Nature, 237, 171-172. doi:10.1038/237171b0

Jirout, J., \& Klahr, D. (2012). Children's scientific curiosity: in search of an operational definition of an elusive concept. Developmental Review, 32(2), 125-160, doi:10.1016/j.dr.2012.04.002.

Keller, H. (1994). A developmental analysis of exploration styles. In H. Keller, K. Schneider, \& B. Henderson (Eds.), Curiosity and exploration (pp. 199-212). Berlin: Springer-Verlag. doi:10.1007/978-3-642-77132-3_11

Klahr, D., \& Dunbar, K. (1988). Dual search space during scientific reasoning. Cognitive Science, 12, 1-48. doi:10.1207/s15516709 $\operatorname{cog} 1201 \_1$

Klahr, D., Zimmerman, C., \& Jirout, J. (2011). Educational interventions to advance children's scientific thinking. Science, 333(6045), 971-975. doi:10.1126/science.1204528

Mishra, S., \& Iyer, S. (2015). An exploration of problem posing-based activities as an assessment tool and as an instructional strategy. Research and Practice in Technology Enhanced Learning, 10(5), 119. doi:10.1007/s41039-015-0006-0

OECD. (2013). PISA 2012 Assessment and analytical framework: mathematics, reading, science, problem solving and financial literacy. Paris: OECD Publishing. doi:10.1787/9789264190511-en

OECD. (2017). PISA 2015: Collaborative problem-solving framework. Paris: OECD Publishing. Retrieved from http://www.oecd.org/pisa/pisaproducts/Draft\%20PISA\%202015\%20Collaborative\%20Problem\%20Sol ving\%20Framework\%20.pdf

Poddiakov, A. (1992). Teaching preschoolers combinatory experimentation. Journal of Russian and East European Psychology, 30(5), 87-96. doi:10.2753/RPO1061-0405300587

Poddiakov, A. (2011). Didactic objects for development of young children's combinatorial experimentation and causal-experimental thought. International Journal of Early Years Education, 19(1), 6578. doi:10.1080/09669760.2011.571001

Poddiakov, A. (2012). Complex problem solving at PISA 2012 and PISA 2015: Interaction with complex reality. Obrazovatel'naya Politika, 6, 34-53. (in Russian).

Poddiakov, A. (2014). Complicology: study of developing, diagnosing and destructive difficulties. Moscow: HSE Publishing House. (in Russian)

Poddiakov, A. (2017). Exploratory and counter-exploratory objects: design of meta-affordances. The Russian Journal of Cognitive Science, 4(2-3), 49-59. Retrieved from http://www.cogjournal.ru/4/3/pdf/PoddiakovRJCS2017.pdf (in Russian)

Poddiakov, N. (1959). Conditions of transformations of executive actions into exploratory ones. Reports of Academy of Educational Sciences of RSFSR, 5, 85-88. (in Russian)

Poddiakov, N. (1960). Orientating activity of preschoolers when forming and automating practical actions ( $\mathrm{PhD}$ dissertation). Institute of Psychology of Academy of Educational Sciences of RSFSR, Moscow. (in Russian)

Poddiakov, N. (1977). The thinking of a preschool child. Moscow: Pedagogika. (in Russian)

Poddiakov, N. (2011). Searching, experimenting and the heuristic structure of a preschool child's experience. International Journal of Early Years Education, 19(1), 55-63. doi:10.1080/09669760.2011.571000

Poddiakov, N. (2012). Features of mental development and self-development in the preschool child. Journal of Russian and East European Psychology, 50(2), 54-63. doi:10.2753/RPO10610405500207 
Poddjakow, N. (1981). Die denkentwicklung beim vorschulkind. Berlin: Volk und Wissen Volkseigener Verlag. (in German)

Riegler, A. (1998). "The end of science": can we overcome cognitive limitations? Evolution and Cognition, 4(1), 37-50.

Schauble, L. (1990). Belief revision in children: the role of prior knowledge and strategies for generating evidence. Journal of Experimental Child Psychology, 49(1), 31-57. doi:10.1016/00220965(90)90048-D

Schauble, L., Klopfer, L. E., \& Raghavan, K. (1991). Students' transition from an engineering model to a science model of experimentation. The Journal of Research in Science Teaching, 28(9), 859-882. doi:10.1002/tea.3660280910

Schulz, L. E., \& Bonawitz, E. B. (2007). Serious fun: Preschoolers engage in more exploratory play when evidence is confounded. Developmental Psychology, 43(4), 1045-1050. doi:10.1037/00121649.43.4.1045

Snider, J., Plank, M., Lynch, G., Halgren, E., \& Poizner, H. (2013). Human cortical $\theta$ during free exploration encodes space and predicts subsequent memory. The Journal of Neuroscience, 33(38), 15056-15068. doi:10.1523/JNEUROSCI.0268-13.2013

Alexander N. Poddiakov - professor, Department of Psychology, Faculty of Social Sciences, National Research University Higher School of Economics; senior research fellow, Institute of psychology, Russian Academy of Sciences, D.Sc.

Research area: cognitive psychology, developmental psychology, educational psychology.

E-mail: apoddiakov@hse.ru

Nikolay N. Poddiakov - Full Member of the Russian Academy of Education, D.Sc.

Research area: cognitive psychology, developmental psychology, educational psychology.

\title{
Интерактивные исследовательские объекты: от лабораторных экспериментов к массовым практикам XXI в.
}

\author{
А.Н. Поддьяков ${ }^{\mathrm{a}, \mathrm{b}}$, Н.Н. Поддьяков \\ ${ }^{a}$ Национальный исследовательский университет «Высшая школа экономики», 101000, Россия, \\ Москва, ул. Мясницкая, д. 20 \\ ${ }^{\text {b}}$ ФГБУН Институт психологии РАН, 129366, Москва, ул. Ярославская, д. 13, к. 1
}

\section{Резюме}

В статье обсуждаются истории и современные методы создания и применения интерактивных исследовательских объектов и миров, которые способствуют проявлению любознательности у человека, при этом для их освоения и достижения практических результатов требуются исследования и эксперименты. Разработка, использование и демонстрация разнообразных исследовательских объектов (игровых, образовательных, психодиагностических и др.) в различных сферах жизни отражают все более распространенное представление о том, что одна из основных способностей человека, которая необходима сегодня и ока- 
жется востребованной в будущем, - это способность совладания с новизной, в том числе посредством активных исследований и экспериментов. Определены пять взаимосвязанных направлений развития и популяризации исследовательских объектов: наука, образование, инструменты оценивания, игровые практики, а также литература, искусство, официальная и неофициальная журналистика. Обсуждаются особенности специально разработанных интерактивных исследовательских объектов и миров в контексте подготовки к столкновению с новизной и сложностью. Представлен треугольник тестов интеллекта, креативности и исследовательского поведения в пространстве «регламентированность - свобода». Описаны два типа мотивационных проблем, возникающих при исследовании новых объектов: исследование ради самого процесса познания и исследование ради желаемых практических результатов. Возникает вопрос об особенностях исследовательских объектов, стимулирующих постановку и решение эпистемических, а не прагматических задач, и наоборот. В заключении сформулированы возможные причины массового развития и реализации исследовательских объектов и миров.

Ключевые слова: интерактивные исследовательские объекты, экспериментирование, исследовательское поведение, интеллект, креативность, образование, игры.

Поддьяков Александр Николаевич - профессор, департамент психологии, факультет социальных наук, Национальный исследовательский университет «Высшая школа экономики»; главный научный сотрудник, Институт психологии Российской академии наук, доктор психологических наук, профессор.

Сфера научных интересов: когнитивная психология, психология развития, психология образования.

Контакты: apoddiakov@hse.ru

Поддьяков Николай Николаевич - действительный член Российской академии образования, доктор психологических наук, профессор.

Сфера научных интересов: когнитивная психология, психология развития, психология образования. 


\title{
Cтатьи
}

\section{РОЛЬ ИНДИВИДУАЛЬНЫХ ЦЕННОСТЕЙ И МОТИВАЦИИ В ЛИТЕРАТУРНОЙ ПРОДУКТИВНОСТИ ПОЭТОВ И ПРОЗАИКОВ}

\author{
М.А. БУЛЬЦЕВА ${ }^{\text {a }}$ Н.М. ЛЕБЕДЕВА ${ }^{\mathrm{a}}$ \\ ${ }^{a}$ Национальный исследовательский университет «Высшая школа экономики», 101000, Россия, \\ Москва, ул. Мясниикая, д. 20
}

\begin{abstract}
Резюме
Цель данного исследования состоит в идентификации различий в факторах, связанных с творческой продуктивностью в разных микродоменах литературной креативности (написание прозы и поэзии). Проводится анализ взаимосвязей между индивидуальными ценностями (по Ш. Шварцу), мотивацией (по Э. Деси и Р. Райану) и творческой продуктивностью у поэтов и прозаиков, измеряемыми по частотному принципу. Выборка состояла из 240 представителей «малой креативности» (на уровне хобби), занимавшихся написанием прозы и/или поэзии в течение последнего года. В эмпирическом исследовании были использованы следующие методики: PVQ-R Ш. Шварца для измерения индивидуальных ценностей; авторский опросник на частоту написания прозы и поэзии, основанный на СBI С. Доллингера; опросник, измеряющий мотивацию креативного поведения, основанный на SDT Э. Деси и Р. Райана. Полученные данные анализировались при помощи факторного анализа, t-критерия Стьюдента, регрессионного анализа и путевого анализа. Было выявлено, что непрофессиональные «поэты» и «прозаики» различаются ценностными приоритетами: у «поэтов» сильнее выражены ценности социального фокуса, а у «прозаиков» - ценности личностного фокуса. Они различаются также набором предикторов творческой литературной продуктивности: так, литературной продуктивности «поэтов» способствуют ценности Открытости изменениям и препятствуют ценности Самопреодоления; а литературной продуктивности «прозаиков» способствуют ценности Сохранения и препятствуют ценности Самопреодоления и Самоутверждения. В исследовании также была определена медиативная роль автономной мотивации во взаимосвязях ценностей с литературной продуктивностью в обеих группах. Таким образом, проведенное исследование раскрывает эвристический потенциал дифференцированного подхода к творческой деятельности посредством изучения креативности на уровне микродоменов.
\end{abstract}

Ключевые слова: креативность, литературное творчество, творческая продуктивность, индивидуальные ценности, мотивация.

Статья подготовлена в результате проведения исследования в рамках Программы фундаментальных исследований Национального исследовательского университета «Высшая школа экономики» (НИУ ВШЭ) с использованием средств субсидии в рамках государственной поддержки ведущих университетов Российской Федерации «5-100». 


\section{Введение}

Креативность, часто рассматриваемая российскими психологами в контексте творческих способностей (Яголковский, 2007), а в западной школе определяемая как создание продукта, полезного и нового с точки зрения социального контекста (Batey, 2012), имеет важнейшее значение в эволюционном развитии человечества (Runco, 2004). Несколько тревожными кажутся результаты исследований, показывающие, что в последние десятилетия во многих сферах наблюдается спад креативности. Так, например, в соответствии с многолетними замерами креативности в США, выполненными на многотысячных выборках, в 1998 и 2008 гг. по сравнению с 1990 г. снизились оригинальность генерируемых идей и продуктивность, несколько упала также и мотивация к творческой деятельности (Kyung, 2011). Примечательно, что, как оказалось, спад наблюдается не во всех сферах реализации креативности. Например, он действительно фиксируется в области литературного творчества, но не в визуальных искусствах (Weinstein et al., 2014).

При этом креативность долгое время являлась и до сих пор остается достаточно дискуссионным объектом исследований в силу своей многоаспектности. После многолетних споров о сущности креативности и введения в оборот понятий, охватывающих разные ее аспекты, в центре внимания оказались вопросы ее дифференцируемости и ее предикторов. В самом общем виде можно определить три основных подхода к рассмотрению «множественности» креативности: как неделимой, универсальной способности; выделение в креативности универсальной и дифференцированной частей; как качества, дифференцированного для разных доменов (Бушина, Лебедева, 2014). Последний подход зарекомендовал себя как наиболее удачный с точки зрения практической применимости (Baer, 1994, 1996). Кроме того, он позволяет более детально концептуализировать креативность, следуя «от общего к частному». Так, данный подход, реализованный в модели креативности Дж. Баера и Дж. Кауфмана (Baer, Kaufman, 2005), позволил определить, что, несмотря на необходимые для актуализации креативности единые условия (например, уровень интеллекта), креативность к ним не сводится и дифференцируется на отличные друг от друга домены и более узкие направления творческой деятельности - микродомены (микродомен - конкретизированный, практически сведенный до специфических заданий уровень творческой деятельности), а потому данный подход является наиболее приемлемым при изучении креативности людей, занимающихся литературной - поэтической и прозаической - деятельностью (далее «поэтов» и «прозаиков» соответственно).

При этом сам анализ может идти на разных уровнях креативности (Kaufman, Beghetto, 2009): на уровне мини-креативности, связанной с новыми и лично значимыми интерпретациями, идеями и представлениями человека (интроспективная и субъективная сторона креативности) (Helfand et al., 2016); на уровне «малой креативности», представляющей собой непрофессиональное и повседневное творчество, которое может осуществляться ежедневно для самовыражения и адаптации к изменениям (Hennesey, Amabile, 2010); 
на уровне профессиональной креативности, фокусирующейся на людях, которые профессионально занимаются той или иной творческой деятельностью (Kaufman, Beghetto, 2009); и, наконец, на уровне большой креативности, связанной с существенно влияющими на общество и культуру креативными достижениями (Hennesey, Amabile, 2010). Однако случаи «большой креативности» не встречаются повсеместно и использование только их в рамках изучения креативности накладывает существенные ограничения на валидизацию результатов, а также способствует распространению стереотипов, что творчество - удел очень небольшого количества выдающихся людей (Beghetto, Kaufman, 2007). В данном исследовании анализ проводится на уровне «малой креативности», т.е. на уровне непрофессионального литературного творчества, воплощающегося в том или ином литературном продукте.

Значение имеет также то, как именно операционализируется и измеряется креативность в каждом конкретном случае: применяется ли качественный или количественный анализ, оценка продуктов, характеристики творческой личности или процесса, самооценка или оценки экспертов. В данном исследовании, как следует из названия, применяется количественный подход, измеряющий частоту креативного поведения (так называемую продуктивность творчества). В соответствии с подходом Дж. Гилфорда (Guilford, 1967) креативность характеризуется сразу несколькими показателями, очень важным является количество генерируемых идей. Эта мысль развивается в работах современных исследователей, использующих «беглость идей» для разработки нового типа инструментов измерения креативности (Sharma, Rastogi, 2009). Было показано, что этот тип измерений, по факту обращенный не столько к самой креативности, согласно ее классическому определению, сколько к продуктивности творческого поведения, является «наиболее надежным методом определения креативных личностей» (Hocevar, 1981), а показатели по нему позитивно коррелируют с другими способами измерения креативности (Jauk et al., 2014; Agnoli et al., 2016). Кроме того, творческая продуктивность напрямую взаимосвязана с мотивационными факторами, в итоге воплощающимися в частоте конкретного творческого поведения.

Необходимо отметить, что исследований на уровне микродоменов на любом уровне креативности с любым способом ее операционализации чрезвычайно мало. И данная работа представляет собой попытку проверить на примере литературной креативности, есть ли смысл углубляться в исследовании креативности, по крайней мере в контексте ее количественной характеристики, и ее предикторов на уровень микродоменов. Чтобы выявить целесообразность изучения микродоменов, обратимся к предикторам креативности и творческой продуктивности и посмотрим, одинаковое ли влияние оказывают связанные с ними факторы на творческую продуктивность в рамках создания прозаических и поэтических литературных произведений. При этом важно отметить, что в соответствии с используемым подходом (Baer, Kaufman, 2005) фактором, определяющим выбор определенного микродомена (а значит, и частоту творческого поведения в нем), является мотивационная составляющая. Это соответствует сложившейся в современных исследованиях 
идее о приоритетном внимании к индивидуальным ценностям и мотивации при рассмотрении предикторов креативности. Представляя ценности как мотивационные триггеры (Feather, 1992), стоит также принять во внимание и типы мотивации, способные играть роль независимого предиктора и выступать в роли посредника между ценностями и поведением (Parks-Leduc, Guay, 2009), в частности творческим поведением.

Индивидуальные ценности, определяемые как трансситуативные цели, различающиеся по важности и служащие в качестве руководящих принципов в жизни людей (Schwartz, 2012), рассматриваются исследователями в качестве предикторов креативности и творческой продуктивности (Dollinger et al., 2007; Kasof et al., 2007), при этом теоретически и методологически ценности часто рассматриваются как каузально связанные с поведением (например, было доказано, что ценности влияют на политическую активность при голосовании - Leimgruber, 2011). Относится это и к творческому поведению (Лебедева, Бушина, 2015). Система ценностей в обновленной теории Шварца это упорядоченный круговой континуум (рисунок 1). Соседние ценности совместимы или нейтральны, а противолежащие противоречат друг другу. Объединяясь, 19 индивидуальных ценностей образуют 4 ценности высшего порядка: Открытость изменениям, Самоутверждение, Сохранение, Самопреодоление, а далее метаценности личностного или социального фокуса (Шварц и др., 2012).

У более творчески продуктивных людей сильнее выражены такие ценности, как самостоятельность, стимуляция, благожелательность, слабее - традиция, безопасность и конформность. Однако разные ценности в разной степени значимы для творческой продуктивности и креативности в целом в рамках отдельных доменов (Dollinger et al., 2007; Kasof et al., 2007; Sousa,

Рисунок 1

Круговой мотивационный континуум 19 ценностей (Шварц и др., 2012)

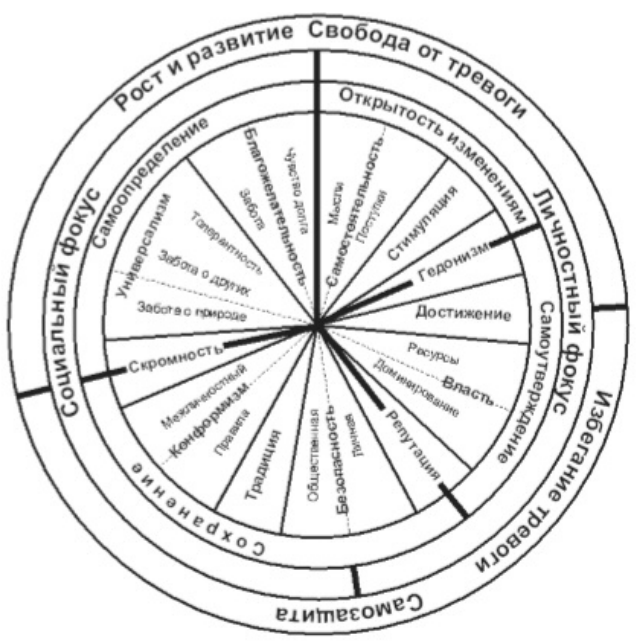


Koelho, 2011). Так, ценности Открытости изменениям позитивно, а ценности Сохранения негативно влияют на литературную творческую продуктивность (Черкасова, 2013; Лебедева, Бушина, 2015).

Мотивация - движущая сила, инициирующая поведение, - также рассматривается как предиктор креативности, в том числе творческой продуктивности. В теории самодетерминации Э. Деси и Р. Райана выделяют пять мотивационных регуляций, которые можно сгруппировать в три типа мотивации (Лебедева, Бушина, 2015) по тому, что́ (цель) или кто именно инициирует мотивирующие воздействия. Первая - контролируемая мотивация, связанная с факторами, внешними по отношению к деятельности и самому человеку, и включающая стороннюю (external) регуляцию поведения, например награда, общественное одобрение или наказание, и интроецированную (introjected) регуляцию, связанную с межличностными отношениями и их последствиями, например обязанностями, долгом, виной, стыдом и тревогой (по Э. Деси и Р. Райану). Вторая - автономная мотивация, связанная с факторами, внутренними по отношению к человеку, она включает в себя идентифицированную (identified) (присваивание мотива, установок и предпочтений) и интегрированную (integrated), (объединяющую важные жизненные цели и ценности) регуляции (по Э. Деси и Р. Райану). Третья - внутренняя мотивация, связанная с факторами, внутренними по отношению к деятельности, и получением удовольствия от нее (Deci, Ryan, 2000). Так как автономная мотивация включает в себя регуляции, связанные с интернализированными целями (Ibid.), именно она - главный претендент на роль посредника между ценностями и креативностью. Следует отметить и опосредующую роль внутренней мотивации в отношениях Открытости изменениям и креативности (Prabhu et al., 2008), ведь между этой чертой личности и ценностями Открытости изменениям существует сильная связь (Roccas et al., 2008).

Нас интересует, различаются ли «поэты» и «прозаики» в ценностных приоритетах и как разные типы мотивации опосредуют влияние ценностей на творческую продуктивность в качестве важной характеристики креативного поведения. Хотя предыдущими исследованиями установлено, что разные ценности взаимосвязаны с креативностью и творческой продуктивностью в разных доменах, однако взаимоотношения ценностей, мотивации и творческой продуктивности на уровне микродоменов пока не известны, что и составляет проблему настоящего исследования. Цель исследования состоит в том, чтобы идентифицировать различия в ценностях и типах мотивации, связанных с литературной продуктивностью поэтов и прозаиков, а также определить роль мотивации в отношениях между ценностной сферой и продуктивностью в различных типах литературной креативности.

Ранее было выявлено, что в поэзии наблюдается недостаточно ясное разделение между субъектом и объектами творчества, в то время как проза связана с «наличием повествовательного самосознающего субъекта, который отделен от объекта творчества и имеет более реалистичное и интегративное отношение к нему» (Forgeard et al., 2013). Более того, анализ существующих исследований показал, что продукт поэтического творчества ориентирован социально 
в большей степени, чем проза. В частности, считается, что поэзия в отличие от прозы, в первую очередь, связана не с сюжетом, а с отражением чувств автора и разделением их с другими людьми; сам процесс написания и создания смысла рассматривается как сотворчество (Волькенштейн, 1970; Оганесян, 2013). Более того, поэзия, воспринимаемая читателями как более сложный вид творчества, является лучшим инструментом аттракции, чем проза (Lange, Euler, 2014). Согласуются с этим и высказывания известных поэтов: например, B. Маяковский говорил, что поэт должен чувствовать настроение людей, быть ориентированным на то, чем общество живет в данный момент и что ему требуется (Маяковский, 1959). Напротив, люди, вовлеченные в написание прозы, склонны рассматривать своего идеального читателя как человека, очень похожего на них во взглядах, который не будет генерировать новые смыслы на основании их посыла, но увидит то же самое, что хотел выразить автор (Michael, 2016). На наш взгляд, подобные различия могут влиять на ценностные приоритеты поэтов и прозаиков. Также считается, что к поэзии более склонны в юности, а к прозе - в зрелости (Blumrosen-Sela, 2002; Lange, Euler, 2014). Так как ценностные приоритеты меняются с возрастом (Schwartz, 2006), то ценности Открытости изменениям и Самоутверждения могут играть важную роль в креативности «поэтов», а ценности Сохранения и Самопреодоления - в креативности «прозаиков». То, что даже писательское сообщество разделяет стереотипы об обреченности литераторов на бедность (Rettig, 2011), хотя проза - более коммерциализированная сфера, может сказаться на взаимосвязях литературной креативности и ценностей Самоутверждения. Из-за более жестких правил поэзия считается более «чистым» и сложным видом творчества, она связана с более короткими сроками и акцентом на эмоциях и ассоциациях, а не на сюжете (Blumrosen-Sela, 2002; Forgeard et al., 2013), что может приводить к различиям во влиянии ценностей Сохранения и Открытости изменениям на креативность в этих микродоменах.

Многочисленные исследования показали, что мотивация связана с творчеством и творческой продуктивностью, но отношения эти разнятся в зависимости от подхода к креативности или определенного домена. Так, внутренняя мотивация имеет значимые положительные корреляции с литературной креативностью (Jesus et al., 2013; Sternberg, 2006). При этом влияние внешней мотивации неоднозначно, начиная с негативного (Amabile, 1985) и до исключительно положительного (Boice, 1983; Eisenberger, Rhoades, 2001). Но если мы посмотрим на процедуру и дизайн исследований, то увидим, что в исследовании Т. Амабайл литературную креативность измеряли через написание стихов, в то время как в других исследованиях использовали написание прозы. В контексте влияния мотивации следует также учесть и бо́льшие возможности коммерциализации своих креативных продуктов у «прозаиков» даже на уровне «малой», а не профессиональной креативности. Кроме того, с творческой продуктивностью в обеих группах может коррелировать автономная мотивация, так как именно она связана с самоидентификацией и реализацией своих ценностей и целей, являясь как предиктором, так и посредником в отношениях ценностей и творческой продуктивности. 


\section{Гипотезы исследования}

В результате анализа были сформулированы следующие гипотезы.

Гипотеза 1. Приоритеты индивидуальных ценностей «поэтов» и «прозаиков» различны: у «прозаиков» более выражены ценности личностного фокуса (ценности Открытости изменениям и Самоутверждения) и менее выражены ценности социального фокуса (ценности Сохранения и Самопреодоления), чем у «поэтов».

Гипотеза 2. Различные наборы ценностей связаны с творческой продуктивностью у «поэтов» и «прозаиков»:

$2 a$. Ценности Открытости изменениям и Самопреодоления связаны положительно, а ценности Самоутверждения отрицательно с литературной творческой продуктивностью «поэтов»;

26. Ценности Самоутверждения связаны положительно, а ценности Сохранения и Самопреодоления отрицательно с литературной творческой продуктивностью «прозаиков».

Гипотеза 3. Литературная творческая продуктивность «поэтов» и «прозаиков» связана с разными видами мотивации:

3a. Литературная творческая продуктивность «поэтов» связана отрицательно с контролируемой мотивацией и положительно с автономной и внутренней мотивацией;

3б. Литературная творческая продуктивность «прозаиков» связана положительно с контролируемой, автономной и внутренней мотивацией.

Гипотеза 4. Мотивация опосредует отношения между индивидуальными ценностями и литературной творческой продуктивностью:

4a. Автономная мотивация опосредует отношения между индивидуальными ценностями и литературной творческой продуктивностью;

46. Внутренняя мотивация опосредует отношения между ценностями Открытости изменениям и литературной творческой продуктивностью.

\section{Методика исследования}

\section{Участники исследования}

Выборка состояла из 240 представителей «малой креативности» (повседневная креативность и хобби, а не профессиональная деятельность - определялась по отрицательному ответу на вопрос о том, зарабатывает ли респондент деньги профессиональным написанием поэтических или прозаических художественных текстов), писавших прозу и/или поэзию на русском языке в течение последнего года: 118 «поэтов» (31 мужчина, 87 женщин, средний возраст - 22.6) и 122 «прозаика» (32 мужчины, 90 женщин, средний возраст - 22.8), публиковавшихся в Интернете на специализированных площадках и, таким образом, включенных в пишущее сообщество (а значит, имеющих возможность испытать на себе влияние всех рассматриваемых типов мотивации). При этом респондент относился к «прозаикам», если в 
соответствующем вопросе опросника давал ответ, что за последний год чаще писал прозу, и это подтверждалось измерениями по частоте его креативного поведения в микродоменах; по аналогичному принципу респондент относился к «поэтам»; данные же тех респондентов, кто затруднялся определить, что он писал чаще (т.е. тех, у кого не было выявлено самоидентификации с одной из групп), или чья частота креативного поведения в микродоменах была приблизительно одинаковой, в анализе не использовались.

\section{Memoдbl}

Использовались методики, построенные по типу шкал Ликерта:

- Обновленный опросник (PVQ-R) Ш. Шварца (Шварц и др., 2012), измеряющий 19 ценностей и включающий 57 пунктов - портретных описаний (например, «Для него важно расширять свой кругозор»), степень сходства каждого из которых с собственными чертами респонденту предлагалось оценить по шкале Ликерта от 1 - «Очень похож на меня» до 6 - «Совсем не похож на меня» (при обработке результаты по шкалам были перевернуты). Согласно теории Шварца, данные ценности группируются в ценности-оппозиции более высокого порядка: Сохранение $(\alpha=0.75)$ - Открытость изменениям $(\alpha=0.67)$; Самоутверждение $(\alpha=0.77)-$ Самопреодоление $(\alpha=0.77)$.

- Авторский количественный опросник, измеряющий литературную творческую продуктивность через частоту написания прозы и поэзии, разработанный на основе опросника С. Доллингера (Dollinger et al., 2007): из исходного опросника были удалены вопросы, не связанные с литературной креативностью, и добавлены вопросы в соответствии с российской системой литературных жанров. Опросник прошел проверку с помощью когнитивного интервью и факторного анализа (согласованность шкал, измеряющих литературную продуктивность в написании поэзии $-\alpha=0.74$, в написании прозы $-\alpha=0.76$, в целом $\alpha=0.53)$. Опросник состоит из 13 пунктов, представляющих собой описание видов креативного поведения в этих двух микродоменах в соответствии с российской системой литературных жанров. В инструкции респондентов просят выбрать из предложенного списка те деятельности, в которые они были активно включены на протяжении последних 12 месяцев. Для ответа использовалась 4-балльная шкала: 1 - «Никогда не делал», 2 - «Делал один или два раза», 3 - «Делал 3-5 раз», 4 - «Делал больше пяти раз».

- Опросник, измеряющий мотивацию, разработанный в Международной лаборатории социокультурных исследований (МНУЛ СКИ) НИУ ВШЭ на основе теории Э. Деси и Р. Райана (Deci, Ryan, 2000), включающий в себя в качестве вопросов описание мотивационных регуляций по двум видам креативной деятельности. Данный опросник мотивации креативного поведения, разработанный в МНУЛ СКИ на основе теории саморегуляции Деси и Райана (Лебедева, Бушина, 2015: $\alpha=0.72)$, включает в себя два вида поведения и пять причин, объясняющих каждый из этих двух видов поведения (у нас - написание прозы и написание поэзии): причина $1-$ «од воздействием внешних влияний; наград или наказаний», причина $2-$ «Чтобы получить одобрение 
или избежать чувства стыда», причина 3 - «Потому что это важно для меня», причина 4 - «Это свободный выбор после серьезного обдумывания», причина 5 - «Потому что это мне нравится». Оценка причины регуляции производилась с помощью пятибалльной шкалы от 1 - «Совсем не по этой причине» до 5 - «Именно по этой причине». Оценка мотивации креативного поведения производилась с помощью трех шкал, отражающих мотивацию поведения в соответствии с теорией Деси и Райана: контролируемую (Причина $1+$ Причина 2), автономную (Причина 3 + Причина 4), внутреннюю (Причина 5).

Респонденты также указывали возраст и пол, регион проживания, в какой вид литературной креативности (написание прозы или поэзии) они были больше вовлечены в течение последнего года, зарабатывали ли они деньги профессиональным написанием художественных текстов.

\section{Прочедура}

Опросник был размещен на платформе Qualtrix и заполнялся респондентами индивидуально, без контакта с интервьюером. Среднее время заполнения опросника составило 25 минут.

\section{Результаты}

Данные были обработаны в программах Amos (22 версия) and SPSS (17 версия) при помощи методов: t-критерии Стьюдента для сравнения средних, регрессионный анализ и путевой анализ с оценкой опосредующих эффектов.

Описательные статистики и ценностные приоритеть «поэтов» и «прозаиков»

Сравнение средних (таблица 1) по переменным в разных группах показало, что, хотя общий уровень литературной продуктивности поэтов и прозаиков статистически не различается (а значит, мы можем сравнивать их по другим критериям), их продуктивность в разных микродоменах, а также выраженность индивидуальных ценностей и внутренней мотивации различны.

Гипотеза 1 также проверялась через сравнение средних. Межгрупповое сравнение показало бо́льшую выраженность ценностей социального фокуса и меньшую - личностного фокуса у «поэтов», чем у «прозаиков».

Таким образом, первая гипотеза подтвердилась: действительно, у «поэтов» сильнее выражены ценности социального фокуса (ценности Сохранения и Самопреодоления) и слабее личностного фокуса (ценности Открытости изменениям), чем у «прозаиков».

Взаимосвязь ценностей и литературной продуктивности у «поэтов» и «прозаиков»

Анализ взаимосвязи ценностей и литературной продуктивности проводился при помощи линейного регрессионного анализа и предполагал каузальную 
Таблица 1

Описательные статистики и показатели t-критерия сравнения по основным используемым переменным в группах «поэтов» и «прозаиков»

\begin{tabular}{|l|c|c|c|c|c|c|c|}
\hline \multirow{2}{*}{} & \multicolumn{3}{|c|}{ Поэты } & \multicolumn{3}{c|}{ Прозаики } & \multirow{2}{*}{$\boldsymbol{t}$} \\
\cline { 2 - 8 } & $\mathrm{M}$ & $\mathrm{SD}$ & $\alpha$ & $\mathrm{M}$ & $\mathrm{SD}$ & $\alpha$ & \\
\hline Литературная продуктивность & 1.95 & 0.38 & 0.63 & 2.04 & 0.42 & 0.66 & -1.57 \\
\hline Поэтическая продуктивность & 2.35 & 0.52 & 0.57 & 1.52 & 0.43 & 0.59 & $13.02^{* *}$ \\
\hline Прозаическая продуктивность & 1.55 & 0.37 & 0.36 & 2.55 & 0.59 & 0.59 & $-11.99^{* *}$ \\
\hline Ценности личностногофокуса & 4.37 & 0.34 & 0.75 & 4.52 & 0.63 & 0.71 & $-2.09^{*}$ \\
\hline Ценности социального фокуса & 4.05 & 0.58 & 0.8 & 3.82 & 0.33 & 0.79 & $4.79^{* *}$ \\
\hline Открытость изменениям & 4.72 & 0.59 & 0.66 & 4.91 & 0.58 & 0.67 & $-2.5^{*}$ \\
\hline Самоутверждение & 3.98 & 0.89 & 0.82 & 4.16 & 0.75 & 0.70 & -1.63 \\
\hline Сохранение & 4.19 & 0.85 & 0.79 & 3.92 & 0.83 & 0.72 & $2.47^{*}$ \\
\hline Самопреодоление & 4.65 & 0.65 & 0.77 & 4.42 & 0.69 & 0.76 & $2.44^{*}$ \\
\hline Контролируемая мотивация & 1.43 & 0.54 & 0.49 & 1.46 & 0.65 & 0.37 & -0.35 \\
\hline Автономная мотивация & 3.17 & 1.05 & 0.48 & 3.13 & 1.01 & 0.51 & 0.29 \\
\hline Внутренняя мотивация & 4.35 & 0.85 & & 4.67 & 0.72 & & $-3.18^{* *}$ \\
\hline
\end{tabular}

${ }^{*} p<0.05,{ }^{* *} p<0.01$.

связь на основании предпосылок использованной теоретической модели. Линейный регрессионный анализ (методом enter) связи индивидуальных ценностей и литературной продуктивности у «поэтов» и «прозаиков» (таблица 2) показал, что различные наборы ценностей связаны с литературной продуктивностью в этих группах. У «поэтов» ценности Открытости изменениям способствуют, а ценности Самопреодоления препятствуют литературной продуктивности, а у «прозаиков» ценности Сохранения способствуют, а ценности Самоутверждения и Самопреодоления препятствуют литературной продуктивности.

Таким образом, гипотеза 2 была подтверждена частично: действительно, разные наборы ценностей связаны с литературной продуктивностью у «поэтов» и «прозаиков», однако частные гипотезы о составе этих наборов были подтверждены лишь частично. Так, гипотеза 2a, касающаяся взаимосвязи ценностей и литературной продуктивности в группе «поэтов», подтвердилась только в отношении ценностей Открытости изменениям, а гипотеза 2б, касающаяся взаимосвязи ценностей и литературной продуктивности в группе «прозаиков», подтвердилась только в отношении ценностей Самопреодоления.

\section{Роль мотивации в креативности «поэтов» $и$ «прозаиков»}

Анализ на уровне контролируемой, автономной и внутренней мотивации не обладает высокой прогностической ценностью, регрессионные модели 
Таблица 2

Результаты регрессионного анализа связи ценностей и литературной продуктивности у поэтов и прозаиков

\begin{tabular}{|l|c|c|c|c|}
\hline \multirow{2}{*}{ Группа } & \multicolumn{4}{|c|}{ Ценности } \\
\cline { 2 - 5 } & $\begin{array}{c}\text { Открытости } \\
\text { изменениям }\end{array}$ & Самоутверждения & Сохранения & Самопреодоления \\
\cline { 2 - 5 } & $\beta$ & $\beta$ & $\beta$ & $\beta$ \\
\hline \multirow{2}{*}{$R^{2}$} & $0.39^{* *}$ & $-0.2^{\dagger}$ & -0.05 & $-0.28^{*}$ \\
\hline$F$ & \multicolumn{5}{|c|}{0.13} \\
\hline «Птозаики» & 0.17 & $-0.23^{*}$ & $0.24^{*}$ & $-0.39^{*}$ \\
\hline$R^{2}$ & \multicolumn{5}{|c|}{0.11} \\
\hline$F$ & \multicolumn{5}{|c|}{$3.39^{*}$} \\
\hline
\end{tabular}

${ }^{\dagger} p<0.1,{ }^{*} p<0.05,{ }^{* * *} p<0.01$.

Таблица 3

Результаты регрессионного анализа связи мотивации и литературной продуктивности у «поэтов» и «прозаиков»

\begin{tabular}{|l|c|c|c|}
\hline \multirow{2}{*}{ Группа } & \multicolumn{3}{|c|}{ Тип мотивации } \\
\cline { 2 - 4 } & Контролируемая & Автономная & Внутренняя \\
\cline { 2 - 4 } & $\beta$ & $\beta$ & $\beta$ \\
\hline «Поэты» & 0.1 & $0.19^{\dagger}$ & 0.12 \\
\hline$R^{2}$ & \multicolumn{3}{|c|}{} \\
\hline$F$ & 0.02 & 0.06 & $0.17^{\dagger}$ \\
\hline «Прозаики» & \multicolumn{3}{|c|}{} \\
\hline$R^{2}$ & \multicolumn{3}{|c|}{0.11} \\
\hline$F$ & \multicolumn{3}{|c|}{1.9} \\
\hline
\end{tabular}

${ }^{\dagger} p<0.1$.

(линейный регрессионный анализ методом одновременного включения) для обеих групп статистически незначимы (таблица 3). Но на уровне тенденции у «поэтов» автономная мотивация $(p=0.05)$, а у «прозаиков» внутренняя мотивация $(p=0.07)$ способствуют литературной продуктивности.

Общая гипотеза 3 и частные гипотезы За и Зб были опровергнуты результатами регрессионного анализа (так как модели оказались статистически незначимыми). Хотя на уровне тенденции можно говорить о частичном подтверждении этих гипотез. 


\section{Опосредующие эффекты мотивации во взаимосвязи ценностей и литературной продуктивности}

Для проверки гипотезы об опосредующей роли мотивации были построены модели в AMOS 22 (тестируемая модель представлена на рисунке 2), в которых индивидуальные ценности выступали в качестве независимых переменных, типы мотивации - в качестве посредников, а литературная продуктивность - в качестве зависимой переменной.

Был проведен анализ опосредующих эффектов по методу Барона и Кенни (Baron, Kenny, 1986; Kenny, 2015), в соответствии с которым должны быть выполнены четыре шага для идентификации посредника: 1) проверить, существует ли связь между зависимой и независимой переменными; 2) проверить, существует ли связь между независимой переменной и посредником; 3) проверить, существует ли связь между зависимой и независимой переменными при включении в модель посредника; 4) оценить прямые и косвенные эффекты. В соответствии с первым шагом для анализа опосредующих эффектов в качестве независимой переменной в группе «поэтов» имеет смысл рассматривать ценности Открытости изменениям и Самопреодоления, у «прозаиков» ценности Сохранения, Самоутверждения и Самопреодоления. В соответствии со вторым шагом (таблица 4) в качестве посредника в группе «поэтов» имеет смысл рассматривать автономную и внутреннюю мотивации, а в группе «прозаиков» - все три типа мотивации.

В соответствии с третьим и четвертым шагом были проведены расчеты по частным моделям для групп «поэтов» и «прозаиков». Все модели далее являются адаптациями общей тестируемой модели (рисунок 2), в которых для удобства указаны только статистически значимые связи и стандартизированные коэффициенты.

Рисунок 2

Опосредующая роль мотивации во взаимосвязи ценностей и литературной продуктивности

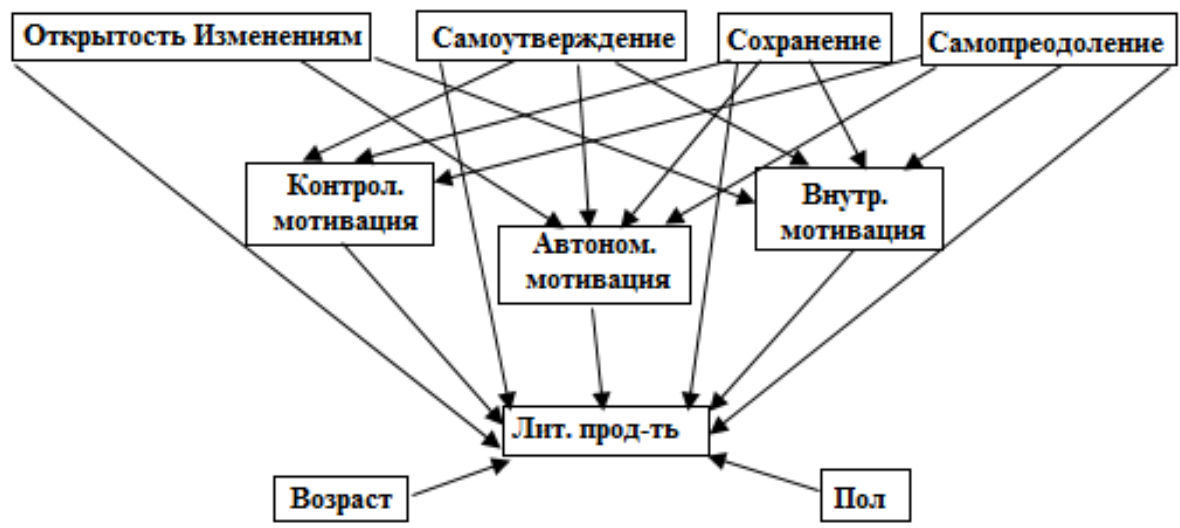


Таблица 4

Результаты регрессионного анализа связи индивидуальных ценностей и мотивации

\begin{tabular}{|l|c|c|c|c|c|c|}
\hline \multirow{2}{*}{} & \multicolumn{3}{|c|}{ «Поэты» } & \multicolumn{3}{c|}{ «Прозаики» } \\
\cline { 2 - 8 } & Контр. & Автон. & Внутр. & Контр. & Автон. & Внутр. \\
\cline { 2 - 8 } & $\beta$ & $\beta$ & $\beta$ & $\beta$ & $\beta$ & $\beta$ \\
\hline Открытость изменениям & -0.07 & $0.26^{*}$ & $-0.3^{*}$ & 0.2 & 0.2 & -0.03 \\
\hline Самоутверждение & 0.09 & -0.13 & $-0.25^{*}$ & 0.1 & -0.07 & $-0.24^{*}$ \\
\hline Сохранение & 0.09 & $0.32^{* *}$ & 0.13 & $0.03^{*}$ & $0.22^{*}$ & 0.12 \\
\hline Самопреодоление & 0.01 & 0.00 & 0.06 & $-0.34^{*}$ & 0.06 & 0.07 \\
\hline$R^{2}$ & 0.02 & 0.16 & 0.08 & 0.8 & 0.1 & 0.08 \\
\hline$F$ & 0.54 & $5.08^{* *}$ & $2.56^{*}$ & $3.65^{* *}$ & $3.39^{*}$ & $2.56^{*}$ \\
\hline
\end{tabular}

${ }^{*} p<0.05,{ }^{* * *} p<0.01$.

Рисунок 3

Опосредующая роль мотивации во взаимосвязи ценностей и креативности у «поэтов»

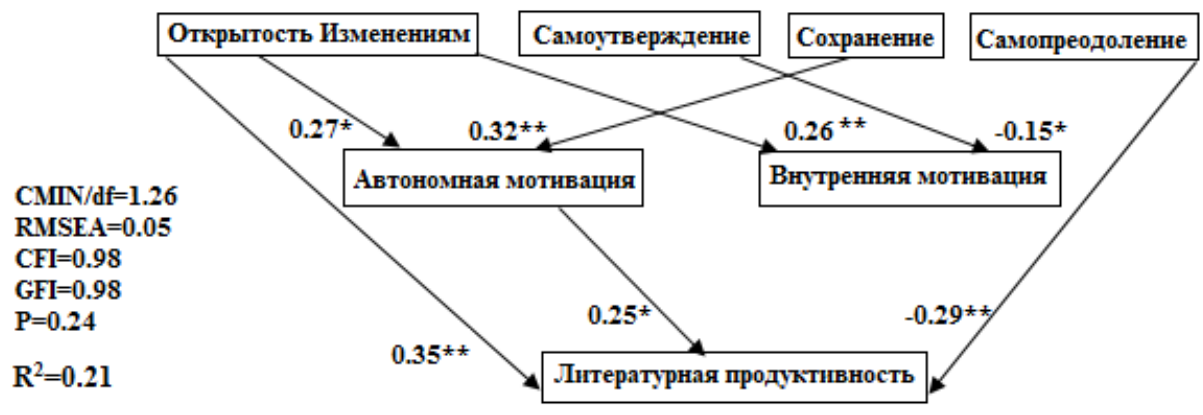

$\mathrm{y}$ «поэтов» (рисунок 3) автономная мотивация частично опосредует эффект, оказываемый ценностями Открытости изменениям на литературную продуктивность (таблица 5). При этом, несмотря на то, что на представленном рисунке прослеживается связь: ценности Сохранения - автономная мотивация - литературная продуктивность, здесь мотивация не является посредником в соответствии с пунктом 1 метода Барона и Кенни.

$\mathrm{Y}$ «прозаиков» (рисунок 4) автономная мотивация полностью опосредует взаимосвязь между ценностями Сохранения и литературной продуктивностью (таблица 6). При этом, несмотря на то, что на рисунке прослеживается связь: ценности Самоутверждения - внутренняя мотивация - литературная продуктивность, здесь мотивация не является посредником в соответствии с пунктом 4 метода Барона и Кенни (не был обнаружен статистически значимый косвенный эффект). 
Таблица 5

Опосредующий эффект мотивации в группе «поэтов»

\begin{tabular}{|c|c|c|c|c|}
\hline \multirow{3}{*}{ Путь } & \multirow{2}{*}{$\begin{array}{l}\text { Модель без } \\
\text { посредника }\end{array}$} & \multicolumn{3}{|c|}{ Модель с посредником } \\
\hline & & Полный эффект & Прямой эффект & Косвенный эффект \\
\hline & $\beta$ & $\beta$ & $\beta$ & $\beta$ \\
\hline $\begin{array}{l}\text { Открытость } \\
\text { изменениям } \rightarrow \\
\text { автономная } \\
\text { мотивация } \rightarrow \\
\text { литературная } \\
\text { продуктивность }\end{array}$ & $0.39 * *$ & $0.4^{* *}$ & $0.35^{* *}$ & $0.06^{*}$ \\
\hline
\end{tabular}

$* p<0.05, * * * p<0.01$.

Рисунок 4

Опосредующая роль мотивации во взаимосвязи ценностей и креативности у «прозаиков»

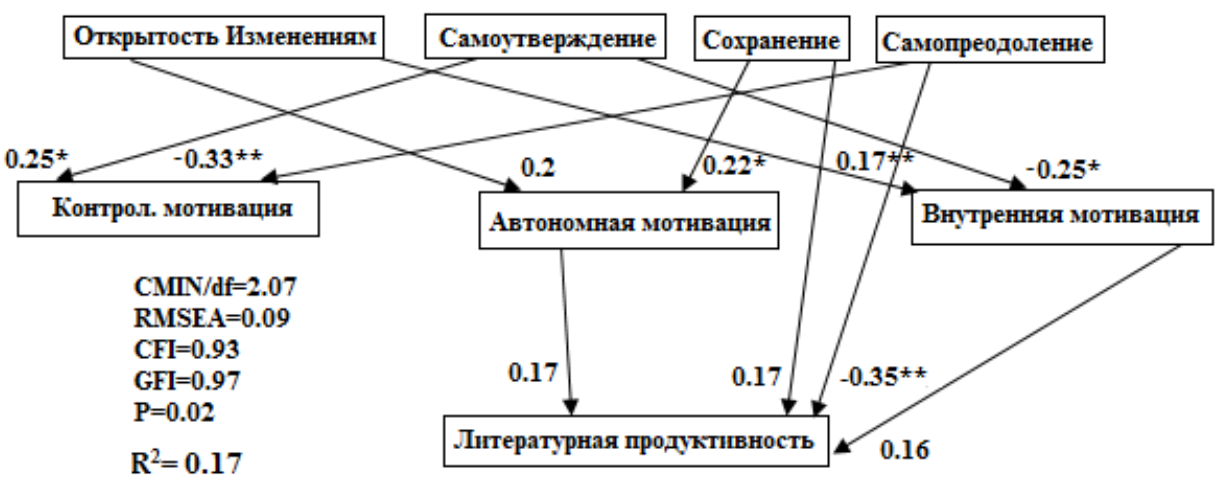

Таблица 6

Опосредующий эффект мотивации в группе «прозаиков»

\begin{tabular}{|l|c|c|c|c|}
\hline \multirow{2}{*}{\multicolumn{1}{|c|}{ Путь }} & \multirow{2}{*}{$\begin{array}{l}\text { Модель без } \\
\text { посредника }\end{array}$} & \multicolumn{3}{|c|}{ Модель с посредником } \\
\cline { 2 - 5 } & $\beta$ & $\beta$ & $\beta$ & $\beta$ \\
\hline $\begin{array}{l}\text { Сохранение } \rightarrow \\
\text { автономная } \\
\text { мотивация } \rightarrow \\
\begin{array}{l}\text { литературная } \\
\text { продуктивность }\end{array}\end{array}$ & $0.24^{*}$ & 0.21 & 0.17 & $0.05^{*}$ \\
\hline $\begin{array}{l}\text { Самоутверждение } \rightarrow \\
\text { внутренняя } \\
\begin{array}{l}\text { мотивация } \rightarrow \\
\text { литературная } \\
\text { продуктивность }\end{array}\end{array}$ & $-0.23^{*}$ & & & \\
\hline
\end{tabular}

${ }^{*} p<0.05, * * * p<0.01$. 
Таким образом, общая гипотеза 4 была подтверждена, как и гипотеза 4а, но опосредующий эффект внутренней мотивации выявлен не был, так что нельзя говорить о подтверждении гипотезы 46.

\section{Обсуждение результатов}

Мы обнаружили разницу в приоритетных ценностях социального и личностного фокуса: у «поэтов» сильнее выражены ценности социального фокуса (ценности Сохранения и Самопреодоления), а у «прозаиков» - личностного (ценности Открытости изменениям). Различие в ценностях Самоутверждения между группами было статистически незначимым, что, возможно, связано с тем, что в выборку были включены представители малой, а не профессиональной креативности. Эти результаты могут объясняться особенностями микродоменов креативности: поэзия более ориентирована на правила и социум, но в то же время и более ограничена в возможностях для личного самоутверждения, чем проза. Также данный результат соответствует используемому подходу к креативности - в модели Баера и Кауфмана (Baer, Kaufman, 2005) мотивационный базис (в нашем понимании - ценности как его составляющая) служит причиной выбора определенного микродомена креативности и проявления определенного творческого поведения.

Мы определили, что литературной продуктивности «поэтов» способствуют ценности Открытости изменениям и препятствуют ценности Самопреодоления; а литературной продуктивности «прозаиков» способствуют ценности Сохранения и препятствуют ценности Самопреодоления и Самоутверждения. Полученные результаты интересны еще и в связи с выявленными приоритетами ценностей - для креативности наиболее значимыми оказались не те ценности, которые в приоритете: так, например, среди «прозаиков», более ориентированных на ценности личностного профиля, связанными с креативностью оказались две группы ценностей социального профиля и лишь одна личностного. На наш взгляд, подобный результат может быть связан как с обобщенным концептом литературной продуктивности (одновременно и написание прозы, и написание поэзии), так и с общим выявленным в социальной психологии феноменом ценностей - передаются последующим поколениям и влияют на установки и поведение в большей степени не наиболее, а наименее выраженные ценности (Boehnke et al., 2007; Grigoryan et al., 2018).

Говоря о статистической незначимости взаимосвязи типов мотивации с креативностью, нужно помнить о том, что размеры выборок были весьма невелики для регрессионного анализа и что использовалась нетрадиционная группировка на три типа мотивации. На уровне тенденции выявлено, что автономная мотивация способствует литературной продуктивности «поэтов», а внутренняя - литературной продуктивности «прозаиков». При этом внутренняя мотивация сильнее выражена у «прозаиков», чем у «поэтов». Возможно, это связано с тем, что поэзия - более социально ориентированное творчество, в то время как внутренняя мотивация концентрирует человека на 
собственном удовольствии, а не на других людях и целях, интернализируемых на уровне автономной мотивации.

Также мы выяснили, что взаимосвязи ценностей Открытости изменениям и Сохранения с литературной продуктивностью опосредуются автономной мотивацией, но в зависимости от микродомена креативности.

Таким образом, различия между микродоменами литературной креативности несколько глубже, чем принято считать, и уходят на уровень индивидуальных ценностей и их взаимосвязи с поведением. Для более глубокого понимания сущности человеческой креативности и ее предикторов, по-видимому, имеет смысл углубляться в исследовании креативности на уровень микродоменов.

К ограничениям данного исследования относятся структура (только представители «малой креативности») и небольшой размер выборки; обобщенный концепт литературной продуктивности в расчетах, количественный подход к креативности, а также относительная культурная однородность выборки. В будущем стоит рассмотреть взаимосвязь ценностей и мотивации не просто с литературной продуктивностью, но конкретно с написанием прозы или поэзии или с их соотношением в литературной креативности пишущих людей. Кросс-культурный анализ может выявить влияние культурной среды на исследуемые феномены.

\section{Литература}

Бушина, Е. В., Лебедева, Н. М. (2014). Изучение креативности в разных сферах. В кн. В. Гриценко (ред.), Теоретические проблемы этнической и кросс-культурной психологии: Материаль Четвертой международной научной конференции 30-31 мая 2014 г. (т. 1, c. 158-161). Смоленск: Смоленский гуманитарный университет.

Волькенштейн, М. (1970). Стихи как сложная информационная система. Наука и жизнь, 1. Режим доступа: http://www.lib.ru/NTL/ARTICLES/volkernsht.txt_with-big-pictures.html

Лебедева, Н. М., Бушина, Е. В. (2015). Влияние ценностей и мотивации личности на креативное поведение и отношение к инновациям. Психология в экономике и управлении, 7(1), 26-35. doi: 10.17150/2225-7845.2015.7(1).26-35

Маяковский, В. В. (1959). Как делать стихи. В кн. В. В. Маяковский, Полное собрание сочинений (т. 12, с. 81-117). М.: Художественная литература. Режим доступа: http://febweb.ru/feb/mayakovsky/texts/ms0/msc/msc-081-.htm

Оганесян, Н. Н. (2013). Практикум по психологии творчества. М.: Флинта.

Черкасова, Л. Л. (2013). Сферы креативности и индивидуальные ценности Ш. Шварца. APRIORI. Серия: Гуманитарные науки, 2, 1-20.

Шварц, Ш., Бутенко, Т. П., Седова, Д. С., Липатова, А. С. (2012). Уточненная теория базовых индивидуальных ценностей: применение в России Психология. Журнал Высшей школы экономики, 9(2), 43-70.

Яголковский, С. Р. (2007). Психология креативности и инноваций: учебное пособие. М.: ГУ ВШЭ.

Ссылки на зарубежные источники см. в разделе References после англоязычного блока. 
Бульцева Мария Александровна - аспирант, стажер-исследователь, Международная научно-учебная лаборатория социокультурных исследований, Экспертный институт, Национальный исследовательский университет «Высшая школа экономики».

Сфера научных интересов: психология креативности, кросс-культурная психология.

Контакты: bulceva@mail.ru

Лебедева Надежда Михайловна - заведующая, Международная научно-учебная лаборатория социокультурных исследований, Экспертный институт; профессор, департамент психологии, факультет социальных наук, Национальный исследовательский университет «Высшая школа экономики», доктор психологических наук, профессор.

Сфера научных интересов: этническая и кросс-культурная психология, межкультурные отношения, аккультурация мигрантов, трансмиссия ценностей, креативность и инновации. Контакты: nlebedeva@hse.ru

\title{
The Role of Individual Values and Motivation in Creative Writing Productivity of Poets and Prose Writers
}

\author{
M.A. Bultseva ${ }^{a}$, N.M. Lebedeva \\ ${ }^{a}$ National Research University Higher School of Economics, 20 Myasnitskaya Str., Moscow, 101000, \\ Russian Federation
}

\begin{abstract}
The aim of this study was to identify differences in factors related to productivity in different micro-domains of literary creativity (writing prose and writing poetry). This study examined the relations between values (according to S. Schwartz's approach), motivation types (according to SDT by E. Deci and R. Ryan) and creative writing productivity among "poets" and "writers". The sample consisted of 240 representatives of "little creativity" involved in writing poetry or prose during last year. The research used such questionnaires for data gathering as revised PVQR by S. Schwartz, authors' questionnaire to measure frequency of creative behavior (based on CBI by S. Dollinger) and questionnaire of motivation to creative behavior developed by the HSE International Scientific Socio-Cultural Laboratory on the basis of E. Deci and R. Ryan's questionnaire. We used such methods of data processing as confirmatory factor analysis, T-test for comparing means, regression analyses and path-analysis in AMOS. We revealed that "poets" and "writers" have differences in values and their relations to creativity. For poets Social Focus values were more important than for prose writers, while for prose writers Personal Focus values were more important than for poets. Different sets of values were related to literary creative productivity among "poets" and "writers": Openness to Change and Self-Transcendence values among "poets"; and Conservation, Self-Enhancement and Self-Transcendence values among "prose writers". Autonomous motivation played a mediator role in the relations between values and creativity in both groups. Thus, the conducted research revealed the heuristic potential of the approach differentiating creativity in micro-domains.
\end{abstract}

Keywords: creativity, creative writing, creative productivity, individual values, motivation. 


\section{References}

Agnoli, S., Corazza, G. E., \& Runco, M. (2016). Estimating creativity with a multiple-measurement approach within scientific and artistic domains. Creativity Research Journal, 28(2), 171-176.

Amabile, T. (1985). Motivation and creativity: Effects of motivational orientation on creative writers. Journal of Personality and Social Psychology, 48, 393-399. doi:10.1037//0022-3514.48.2.393

Baer, J. (1994). Divergent thinking is not a general trait: A multidomain training experiment. Creativity Research Journal, 7, 35-46.

Baer, J. (1996). The effects of task-specific divergent-thinking training. Journal of Creative Behavior, 30, 183-187, doi:10.1002/j.2162-6057.1996.tb00767.x

Baer, J., \& Kaufman, J. C. (2005). Bridging generality and specificity: The Amusement Park Theoretical (APT) model of creativity. Roeper Reviewe, 27, 158-163. doi:10.1080/02783190509554310

Baron, R. M., \& Kenny, D. A. (1986). The moderator-mediator variable distinction in social psychological research: Conceptual, strategic and statistical considerations. Journal of Personality and Social Psychology, 51, 1173-1182.

Batey, M. (2012). The measurement of creativity: From definitional consensus to the introduction of a new heuristic framework. Creativity Research Journal, 24(1), 55-65. doi:10.1080/10400419.2012.649181

Beghetto, R. A., \& Kaufman, J. C. (2007). Toward a broader conception of creativity: A case for "mini-c". Psychology of Aesthetics, Creativity, and the Arts, 1(2), 73-79. doi:10.1037/1931-3896.1.2.73

Blumrosen-Sela, S. (2002). Psychoanalytic explanations for the transition of writers from poetry to prose writing. PSYART: A Hyperlink Journal for the Psychological Study of the Arts. Retrieved from http://www.psyartjournal.com/article/show/blumrosen_sela-psychoanalytic_explanations_for_the_tran

Boehnke, K., Hadjar, A., \& Baier, A. (2007). Parent-child value similarity: The role of zeitgeist.Journal of Marriage and Family, 69, 778-792. doi:10.1111/j.1741-3737.2007.00405.x

Boice, R. (1983). Contingency management in writing and the appearance of creative ideas: Implications for the treatment of writing blocks. Behavior Research and Therapy, 21, 537-543. doi:10.1016/0005-7967(83)90045-1

Bushina, E. V., \& Lebedeva, N. M. (2014). Izuchenie kreativnosti v raznykh sferakh [Studing creativity in different domains]. In V. Gritsenko (Ed.), Teoreticheskie problemy etnicheskoi i kross-kul'turnoi psikhologii: Materialy Chetvertoi mezhdunarodnoi nauchnoi konferentsii 30-31 maya 2014 g. [Theoretical problems of ethnic and cross-cultural psychology: Proceedings of the IV International Scientific conference, 30-31 May, 2014] (Vol. 1, pp. 158-161). Smolensk: Smolenskii gumanitarnyi universitet. (in Russian)

Cherkasova, L. L. (2013). Sfery kreativnosti i individual'nye tsennosti Sh. Shvartsa [Domains of creativity and individual values by S. Schwartz]. APRIORI. Seriya: Gumanitamye Nauki, 2, 1-20. (in Russian)

Deci, E. L., \& Ryan, R. M. (2000). Intrinsic and extrinsic motivations: Classic definitions and new directions. Contemporary Educational Psychology, 25, 54-67. doi:10.1006/ceps.1999.1020

Dollinger, S. J., Burke, P. A., \& Gump, N. W. (2007). Creativity and values. Creativity Research Journal, 19, 91-103. doi:10.1080/10400410701395028

Eisenberger, R., \& Rhoades, L. (2001). Incremental effects of reward on creativity. Journal of Personality and Social Psychology, 81(4), 728-741. doi:10.1037//0022-3514.81.4.728

Feather, N. T. (1992). Values, valences, expectations, and actions. Journal of Social Issues, 48, 109-124.

Forgeard, M. J. C., Kaufman, S. B., \& Kaufman, J. C. (2013). The psychology of creative writing. In G. Harper (Ed.), A companion to creative writing (pp. 320-333). Chichester, UK: John Wiley \& Sons, Ltd. doi:10.1002/9781118325759.ch21 
Grigoryan, L. K., Lebedeva, N., \& Breugelmans, S. M. (2018). A cross-cultural study of the mediating role of implicit theories of innovativeness in the relationship between values and attitudes toward innovation. Journal of Cross-Cultural Psychology. Advance online publication. doi:10.1177/0022022116656399

Guilford, J. P. (1967). Creativity: Yesterday, today and tomorrow. The Journal of Creative Behavior, 1, 3-14.

Helfand, M., Kaufman, J. C., \& Beghetto, R. A. (2016). The Four-C Model of Creativity: culture and context. In V. P. Glăveanu (Ed.), The Palgrave handbook of creativity and culture research (pp. 15-36). London, UK: Palgrave Macmillan.

Hennessey, B. A., \& Amabile, T. B. (2010). Creativity. Annual Review of Psychology, 61, 569-598. doi:10.1146/annurev.psych.093008.100416

Hocevar, D. (1981). Measurement of creativity: Review and critique. Journal of Personality Assessment, 45(5), 450-464.

Jauk, E., Benedek, M., \& Neubauer, A. C. (2014). The road to creative achievement: a latent variable model of ability and personality predictors. European Journal of Personality, 28, 95-105.

Jesus, N., Rus, C. L., Lens, W., \& Imaginário, S. (2013). Intrinsic motivation and creativity related to product: A meta-analysis of the studies published wetween 1990-2010. Creativity Research Journal, 25(1), 80-84. doi:10.1080/10400419.2013.752235

Kasof, J., Chen, C., Himsel, A., \& Greenberger, E. (2007). Values and creativity. Creativity Research Journal, 19(2-3), 105-122. doi:10.1080/10400410701397164

Kaufman, J. C., \& Beghetto, R. A. (2009). Beyond big and little: The four c model of creativity. Reviere of General Psychology, 13(1), 1-12. doi:10.1037/a0013688.

Kenny, D. A. (2015). Mediation. Retrieved from http://davidakenny.net/cm/mediate.htm

Kyung, H. K. (2011). The creativity crisis: The decrease in creative thinking scores on the Torrance Tests of Creative Thinking. Creativity Research Journal, 23(4), 285-295.

Lange, B. P., \& Euler, H. A. (2014). Writers have groupies, too: High quality literature production and mating success. Evolutionary Behavioral Sciences, 8(1), 20-30. doi:10.1037/h0097246

Lebedeva N. M., \& Bushina E. V. (2015). Influence of personal values and motivation with creative behavior and attitude to innovations. Psikhologiya o Ekonomike $i$ Upravlenii [Psychology in Economics and Management], 7(1), 26-35. doi:10.17150/2225-7845.2015.7(1).26-35 (in Russian)

Leimgruber, P. (2011). Values and votes: The indirect effect of personal values on voting behavior. Swiss Political Science Review, 17(2), 107-127.

Mayakovskii, V. V. (1959). Kak delat' stikhi [How to make verses]. In V. V. Mayakovskii, Polnoe sobranie sochinenii [Collected works] (Vol. 12, pp. 81-117). Moscow: Khudozhestvennaya literatura. Retrieved from http://feb-web.ru/feb/mayakovsky/texts/ms0/msc/msc-081-.htm (in Russian)

Michael, H. (2016). How writers write: Exploring the unconscious fantasies of writers. Psychoanalytic Psychology, 33(1), 21-34, doi:10.1037/a0038957

Oganesyan, N. N. (2013). Praktikum po psikhologii tvorchestva [Seminars in psychology of creativity]. Moscow: Flinta. (in Russian)

Parks-Leduc, L., \& Guay, R. P. (2009). Personality, values, and motivation. Personality and Individual Differences, 47(7), 675-684. doi:10.1016/j.paid.2009.06.002

Prabhu, V., Sutton, C., \& Sauser, W. (2008). Creativity and certain personality traits: Understanding the mediating effect of intrinsic motivation. Creativity Research Journal, 20, 53-66. doi:10.1080/10400410701841955

Rettig, H. (2011). The 7 secrets of the prolific: The definitive guide to Overcoming procrastination, perfectionism, and writer's block. Infinite Art. 
Roccas, S., Sagiv, L., Schwartz, S. H., \& Knafo, A. (2008). The big five personality factors and personal values. Personality and Social Psychology Bulletin, 28, 789-801. doi:10.1177/0146167202289008

Runco, M. A. (2004). Creativity. Annual Review Psychology, 55, 657-87. doi:10.1146/annurev.psych.55.090902.141502

Schwartz, Sh. H. (2006). Basic human values: Theory, measurements and applications. Revue Francaise de Sociologie, 47(4), 249-288.

Schwartz, S. H. (2012). Basic personal values and political orientations. In J. H. Aldrich \& K. M. McGraw (Eds.), Improving public opinion surveys: Interdisciplinary innovation and the American national election studies (pp. 63-82). Princeton, NJ: Princeton University Press. doi:10.1515/9781400840298

Schwartz, S., Butenko, T. P., Sedova D. S., \& Lipatova, A. S. (2012). A refined theory of basic personal values: Validation in Russia. Psychology. Journal of Higher School of Economics, 9(2), 43-70. (in Russian)

Sharma, N. K., \& Rastogi, D. (2009). A multicriterial approach to creativity for realistic divergent thinking problems. Journal of the Indian Academy of Applied Psychology, 35(1), 9-16.

Sousa, C. M. P., \& Coelho, F. (2011). From personal values to creativity: evidence from frontline service employees. European Journal of Marketing, 45(7/8), 1029-1050. doi:10.1108/03090561111137598

Sternberg, R. J. (2006). The nature of creativity. Creativity Research Journal, 18(1), 87-98. doi:10.1207/s15326934crj1801_10

Volkenshtein, M. (1970). Stikhi kak slozhnaya informatsionnaya sistema [Poems as a complex information system]. Nauka i Zhizn', 1. Retrieved from http://www.lib.ru/NTL/ARTICLES/volkernsht.txt_with-big-pictures.html (in Russian)

Weinstein, E. C., Clark, Z., DiBartolomeo, D. J., \& Davis, K. (2014). A decline in creativity? It depends on the domain. Creativity Research Journal, 26(2), 174-184. doi:10.1080/10400419.2014.901082

Yagolkovskii, S. R. (2007). Psikhologiya kreativnosti i innovatsii [Psychology of creativity and innovations]. Moscow: HSE Publishing House. (in Russian)

Maria A. Bultseva - research intern, International Laboratory for Socio-Cultural Research, Expert Institute; Ph.D. student, School of Psychology, Faculty of Social Sciences, National Research University "Higher School of Economics".

Research area: psychology of creativity, cross-cultural psychology.

E-mail: bulceva@mail.ru

Nadezhda M. Lebedeva - head, International Laboratory for Socio-Cultural Research, Expert Institute; professor, Department of Psychology, Faculty of Social Sciences, National Research University "Higher School of Economics", D.Sc., professor.

Research area: ethnic and cross-cultural psychology, intercultural relations, acculturation of migrants, values transmission, creativity and innovation.

E-mail: nlebedeva@hse.ru 
Psychology. Journal of the Higher School of Economics.

2018. Vol. 15. N 4. P. 695-710. DOI: 10.17323/1813-8918-2018-4-695-710

\title{
ПСИХОЛОГИЧЕСКОЕ СОСТОЯНИЕ СОВРЕМЕННОГО РОССИЙСКОГО ОБЩЕСТВА: НОВЫЕ ТЕНДЕНЦИИ
}

\author{
А.В. ЮРЕВИЧ \\ ${ }^{a}$ ФГБУН Институт психологии РАН, 129366, Москва, ул. Ярославская, д. 13, к. 1
}

\begin{abstract}
Резюме
В центре внимания автора статьи находится проблема психологического состояния современного российского общества. Для количественной оценки этого состояния был применен разработанный автором композитный индекс, основанный на интеграции шести первичных показателей: индекс смертности от заболеваний нервной системы и органов чувств, индекс смертности от самоубийств, индекс заболеваемости психическими расстройствами, индекс устойчивости семьи, индекс социального сиротства, индекс смертности от убийств. Применение индекса позволило количественно оценить динамику психологического состояния российского общества с 1991 по 2016 г. Автор анализирует эту динамику, соотнося с социально-экономическими и политическими событиями. Анализируется также динамика первичных показателей, входящих в состав композитного индекса. Индекс самоубийств и индекс смертности от убийств имеют динамику, подобную динамике композитного индекса. Индекс смертности от заболеваний нервной системы и органов чувств показал резкое ухудшение с 2012 г. при относительной стабильности в предыдущий 21 год. В то же время индекс заболеваемости психическими расстройствами практически не менялся с течением времени. Индексы разводимости и социального сиротства имеют более сложные тенденции, только отчасти объясняемые общей динамикой. Обсуждается латентный характер изменений некоторых индексов. Приводятся данные других исследований - социологических и психологических, характеризующих психологическое состояние современного российского общества и его динамику. Делается вывод о существовании социопсихосоматических влияний, состоящих в том, что социальные процессы получают отражение в психологическом состоянии граждан, которое, в свою очередь, имеет важные соматические последствия.
\end{abstract}

Ключевые слова: современное российское общество, психологическое состояние, количественная оценка, композитный индекс, динамика, социопсихосоматические влияния.

\section{Количественная оценка психологического состояния российского общества}

По сложившейся в психологической науке традиции психологические статьи принято начинать с констатации актуальности темы. Не хочется нарушать эту

Работа выполнена при поддержке Российского научного фонда, проект № 17-78-30035. 
традицию, тем более что в отечественном психологическом сообществе с некоторых пор следование традициям приветствуется больше, чем введение инноваций. Однако фраза о том, что психологическое состояние современного российского общества является или остается актуальной проблемой, была бы тривиальной либо вообще бессмысленной. Психологическое состояние любого общества является актуальной проблемой, поскольку психологические проблемы имеются в любом, даже в самом благополучном в психологическом плане, обществе, особенно в современном «психологическом обществе» (Сироткина, Смит, 2006) (наверное, более удачным был бы термин «психологизированном»), а любая социальная, экономическая и т.д. проблема имеет ярко выраженный психологический контекст. Современное российское общество, естественно, не только не является исключением, но и как и любое переходное общество, имеет дополнительные психологические проблемы и к тому же обладает своей психологической спецификой, связанной с такими общеизвестными факторами, как особенности российского менталитета и т.п.

В этих условиях закономерно, что разнообразные исследования современного российского общества, осуществляемые в социологии, экономике и других социогуманитарных науках, неизбежно обращаются и к психологическим сюжетам, свидетельством чему могут служить, например, социологические работы, цитируемые в этой статье. Разумеется, и психологи в контексте изучения самых различных проблем - ценностных ориентаций, российского менталитета, доверия и др. - уделяют внимание психологическому состоянию нашего общества, при этом, как правило, давая ему довольно негативные характеристики.

Это состояние является одним из основных объектов изучения и в рамках макропсихологии - психологического изучения глобальных социальных явлений, развиваемой в Институте психологии РАН и в последнее время обретающей все большее количество последователей. При этом прогрессирует количественная макропсихология, основанная на применении количественных оценок, в том числе и психологического состояния общества. Ее основные принципы неоднократно излагались в прежних работах автора и его коллег (Юревич, 2014; и др.), не дублируя изложение которых целесообразно упомянуть лишь их соответствие тенденции к широкому использованию социальных индикаторов, проявляющейся в различных социогуманитарных науках.

Достаточно широкое (хотя, конечно, хотелось бы, чтобы оно было еще более широким) применение получили и количественные индикаторы психологического состояния общества, а также родственные им количественные индикаторы его нравственного состояния и др., причем сейчас, что очень отрадно, они применяются для оценки состояния не только российского общества в целом, но и для оценки и сопоставления состояния различных регионов России. Как автор неоднократно подчеркивал в своих работах (да простит ему читатель такой эгоцентризм), такие индикаторы, как говорили в прежние времена, «не догма, а руководство к действию», они допускают применение самых различных показателей, конкретный набор которых определяется 
задачей исследования, а также их доступностью и другими подобными факторами. Однако и использование стандартизированных индикаторов имеет свои преимущества, давая возможность отслеживать динамику психологического состояния общества и соотносить ее с другими его характеристиками.

Один из таких индикаторов основан на следующей методологии. Композитный индекс психологического состояния общества включает два индекса, в свою очередь объединивших по три первичных показателя (рисунок 1).

Первичные индексы рассчитываются на базе удельных показателей, соотнесенных с численностью населения. Все значения показателей переводятся в баллы от 1 до 10 (чем выше балл, тем выше значение соответствующего индикатора психологического состояния общества). Нормализация - перевод показателей в баллы - осуществляется на основе сопоставления показателей по России с аналогичными показателями более развитых стран (согласно классификации ООН), разрабатываемыми соответствующими международными организациями. Первичный индекс - нормализованная оценка показателя в баллах от 1 до 10 - рассчитывается по формуле:

$$
Y=9 \times \frac{V_{\text {max }}-V_{y}}{V_{\text {max }}-V_{\text {min }}}+1,
$$

где $V_{\mathrm{y}}$ - значение конкретного показателя для России за определенный год, $V_{\max }$ - максимальное значение показателя среди стран данной группы в течение рассматриваемого периода (1990-2016), $V_{\min }-$ минимальное значение соответствующего показателя в указанном международном контексте. Вторичные индексы и композитный индекс рассчитываются как среднеарифметические индексов более низкого порядка.

Подсчет композитного индекса на основе наиболее свежих статистических показателей (напомним с сожалением о систематически запаздывающем характере отечественной статистики) позволил выявить следующую картину (рисунок 2).

Рисунок 1

Структура композитного индекса психологического состояния общества

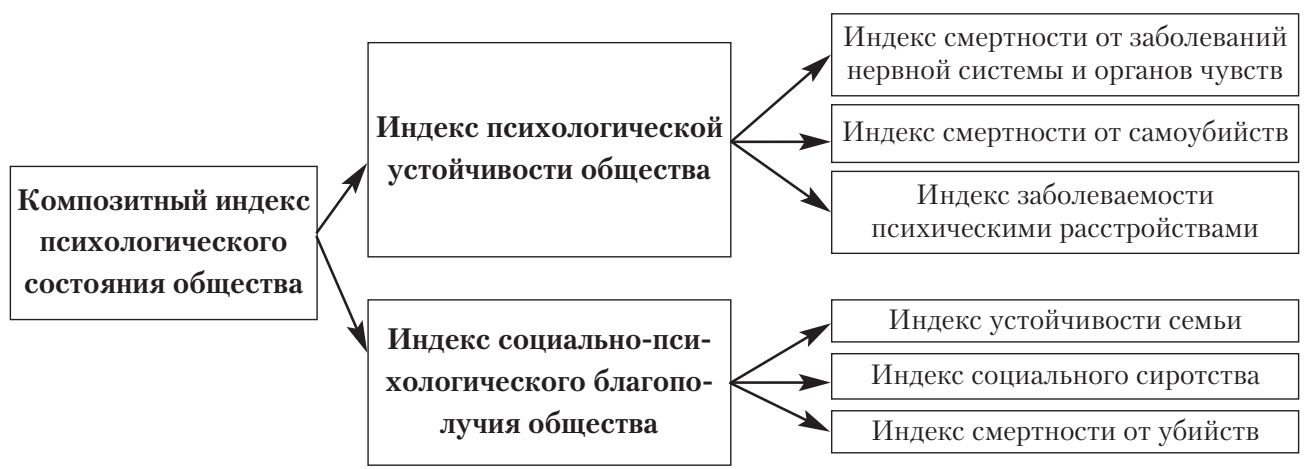


Динамика индекса психологического состояния российского общества, баллы (от 1 до 10)

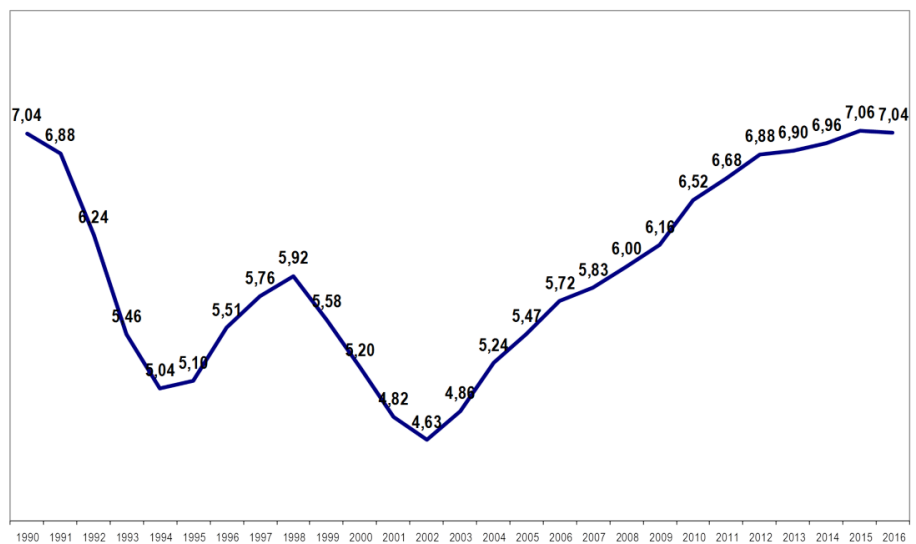

Интерпретация динамики психологического состояния нашего общества с 1990 по 2004 г. была предложена нами ранее (Юревич, 2014; и др.). Как показано на рисунке 2, оно постоянно ухудшалось с 1991 по 1994 г., затем ежегодно улучшалось до 1998 г., впоследствии вновь ухудшалось до 2002 г., после чего обнаружило тенденцию к улучшению.

Подобную динамику несложно объяснить, исходя из общих тенденций в развитии нашего общества и их преломления в психологическом состоянии населения. Радикальные социально-политические реформы, переход к рыночной экономике, «шоковая терапия» и т.п. вызвали дезадаптированность основной части населения к новому общественному устройству, приводя к ежегодному ухудшению его психологического состояния. К 1994 г. произошла психологическая адаптация большей части наших сограждан к реформам, что выразилось в тенденции к улучшению психологического состояния общества, выявляемой в исследованиях. Но в 1998 г. грянул дефолт, повлекший за собой ухудшение материального положения значительной части населения, а также нарастание недоверия к власти, массовое ощущение социальной нестабильности и породивший новую волну ухудшения психологического состояния российского общества. Это ухудшение продолжалось до 2002 г., когда ситуация в стране более или менее стабилизировалась и сформировались новые механизмы адаптации, после чего психологическое состояние вновь стало улучшаться. Таким образом, психологическое состояние российского общества, измеряемое с помощью композитного индекса, чутко реагировало на происходящие в стране изменения, вместе с тем обнаруживая некоторое отставание от экономических и социально-политических событий, требующих времени для адаптации к ним и их психологического «переваривания» населением.

В дальнейшем психологическое состояние нашего общества продолжало улучшаться вплоть до 2015 г. и лишь в 2016 г. обнаружило тенденцию к некоторому, хотя и малозначительному, ухудшению. Этот период захватил «тучные 
годы», когда цены на нефть были высоки, экономическое состояние населения в целом улучшалось и в нашей стране не происходило каких-либо дестабилизирующих ее жизнь событий, за исключением разве что «маршей несогласных» и событий, происшедших на Болотной площади, мало повлиявших на жизнь и психологическое состояние основной части населения. Вместе с тем он захватил экономические кризисы 2008 г. и последних лет, а также воссоединение с Крымом, войну на Донбассе, экономические санкции, обострение противостояния с Западом и др., т.е. в своей поздней части был отнюдь не «спокойным». На фоне всего этого и значимых социальных событий, как в более поздний период, так и их отсутствия, как в более ранний, психологическое состояние нашего общества продолжало улучшаться. Здесь можно допустить три возможности. Либо эти события, даже потенциально обещающие иметь негативное влияние на психологическое состояние наших сограждан, такие как санкции и экономические кризисы, в действительности этого влияния не имели, и оно продолжало улучшаться в силу каких-либо своих имманентных закономерностей. Либо позитивное влияние одних событий, например воссоединения с Крымом, перевешивало негативное влияние других - санкций, противостояния с Западом и др. Либо происходила $а к \kappa y-$ мулящия психологического влияния негативных социальных событий последних лет, которая будет иметь латентный психологический эффект в дальнейшем. В принципе эти возможности не противоречат друг другу, а некоторое ухудшение психологического состояния нашего общества в 2016 г. подтверждает третью возможность. Вместе с тем и такие социальные явления, как противостояние с Западом, могут иметь позитивный психологический эффект за счет массового чувства гордости за нашу страну, удовлетворения от того, что она проводит самостоятельную внешнюю политику и т.П., что подтверждается ростом патриотизма в нашем обществе, фиксируемым эмпирическими исследованиями (Журавлев, Юревич, 2016; и др.). А наличие имманентных закономерностей изменения психологического состояния общества подтверждается его улучшением с 1994 по 1998 г. и в «спокойный» период после 2002 г., когда происходила психологическая адаптация населения к экономическим реформам начала 1990-х и экономическому кризису 1998 г. Из последнего можно заключить, что после негативных социально-экономических событий при условии их отсутствия в последующий период психологическое состояние населения улучшается, наверное, главным образом за счет адаптационных механизмов. В то же время некоторое его ухудшение в 2016 г. порождает тревожные ожидания, проверка оправданности которых требует дальнейшего мониторинга.

Поскольку примененный для выявления динамики психологического состояния нашего общества индекс композитныц̆, имеет смысл проследить, как изменялись в течение рассмотренного периода первичные индексы (рисунки 3-8) (напомним, что чем лучше ситуация по рассмотренному показателю, тем выше значение соответствующего индекса).

Индекс самоубийств обнаружил ту же динамику, что и композитный индекс, за исключением, что он не только не снизился, но, наоборот, возрос в 


\section{Рисунок 3}

Индекс самоубийств

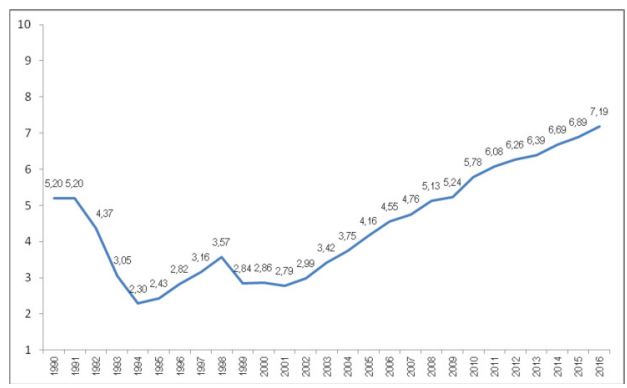

Рисунок 5

Индекс смертности от заболеваний нервной системы и органов чувств

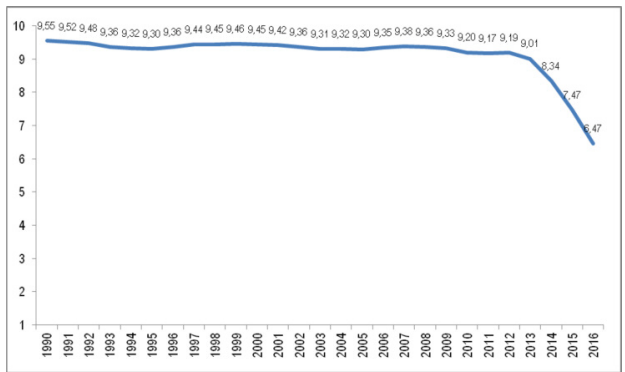

Рисунок 7

Индекс разводимости

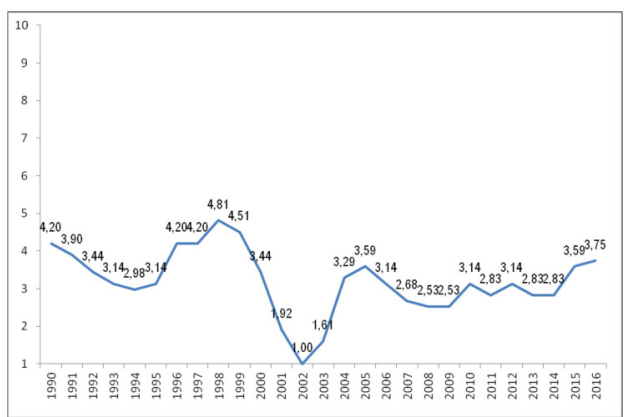

Рисунок 4

Индекс заболеваемости психическими расстройствами и расстройствами поведения

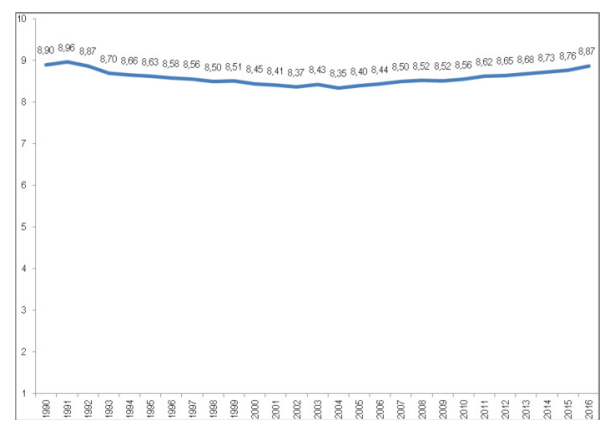

Рисунок 6

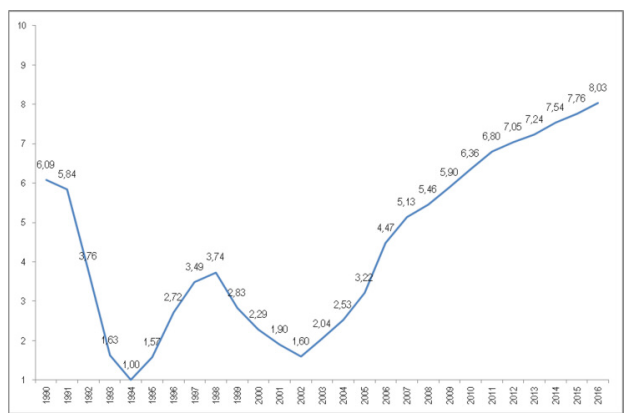

Рисунок 8

Индекс социального сиротства

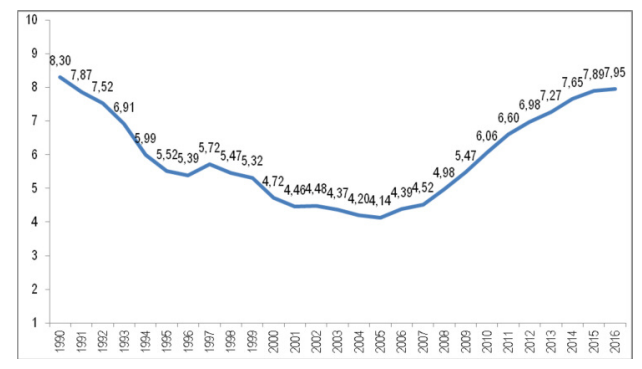

2016 г. Индекс заболеваемости психическими расстройствами и расстройствами поведения вообще практически не изменялся. Индекс смертности от заболеваний нервной системы и органов чувств почти не изменялся до 2013 г., а затем резко пошел вниз. Индекс смертности от убийств тоже изменялся син- 
хронно с композитным индексом, но, как индекс самоубийств, не снизился в 2016 г. Индекс разводимости изменялся так же, как композитный показатель, до 2005 г., а затем обнаружил сложную динамику, то снижаясь, то возрастая. Индекс социального сиротства нелинейно снижался до 2005 г., затем возрастал, а в 2016 г., как и композитный индекс, несколько снизился.

Естественно, каждый из первичных показателей имеет самостоятельный и не только психологический смысл, а динамика каждого из них, например количества самоубийств или социальных сирот, результирует самые различные факторы. Не ставя в данном контексте очень сложную (и имеющую самостоятельное значение) задачу анализа этой динамики, оценим ее лишь в наиболее глобальном контексте - общих изменений в нашей стране. Заболеваемость психическими расстройствами и расстройствами поведения оказалась приктически независимой от этих изменений, что вообще довольно странно и плохо поддается объяснению. Показатель смертности от заболеваний нервной системы и органов чувств также не реагировал на наиболее существенные события в жизни нашего общества до 2013 г., что тоже малопонятно, а затем стал резко возрастать. Последнее можно объяснить тем, что этот показатель либо очень быстро реагирует на события последних лет (но тогда странно, что он практически не реагировал на более ранние существенные события, такие как, например, дефолт и экономические кризисы), либо аккумулирует более (причем намного) ранние события. Социальное сиротство, во многом зависимое от социально-психологической атмосферы в семьях и т.п., по всей видимости, является наиболее «запаздывающим» показателем, реагирующим на социальные изменения с большим временны́м лагом. Кроме того, его масштаб, вероятно, существенно сократился под влиянием Программы поддержки материнства и других государственных программ. Количество разводов чутко реагировало на социальные изменения в стране до 2005 г., а затем изменялось скачкообразно, по всей видимости, попав под влияние каких-то других факторов. В данной связи отметим, что в отличие от других первичных показателей психологического состояния общества этот показатель не носит однозначно негативного характера (см.: Юревич, 2014), и хотя распад семьи принято считать негативным событием, он может приводить к формированию новой и более счастливой семьи, может быть следствием улучшения экономическогого состояния общества (например, разбогатевший муж заводит себе молодую и красивую жену или жена - мужа), тесно связан с такими факторами, как любовь и ее угасание, и т.п. Что же касается убийств и самоубийств, то они обнаружили в целом ту же динамику и зависимость от социальных событий, что и композитный индекс, с тем различием, что они не снизились в 2016 г. Последнее, очевидно, свидетельствует о том, что происходящее в нашем обществе в последние годы пока не склоняет наших сограждан ни к убийствам, ни к самоубийствам, а порождает другие формы психологического и социального реагирования.

Наибольшую тревогу из рассмотренных первичных показателей, естественно, вызывает смерность от заболеваний нервной системы и органов чувств, резко возрастающая с 2013 г., на которую органам нашей власти, безусловно, 
стоит обратить внимание. По всей видимости, за ней стоят какие-то сложные механизмы соматизащии социальных процессов - социопсихосоматизации, приводящие к тому, что эти процессы могут иметь не всегда понятные психосоматические последствия.

По поводу же композитного индекса в целом можно констатировать, что он является результирующей для показателей, которые хотя и обнаруживают некоторые элементы общей динамики, в то же время не всегда вписываются в нее, иногда обнаруживая и собственную динамику. Это обстоятельство, возможно, в какой-то мере ставит под сомнение правомерность единого композитного индекса (отчасти напоминающего «среднюю температуру по больнице»), но все же, скорее, является следствием сложности и многокомпонентности такого понятия, как «психологическое состояние общества».

\section{Другие оценки психологического состояния нашего общества}

Имеет очевидный смысл соотнести выявленную картину с другими оценками психологического состояния нашего общества, не претендуя, естественно, на исчерпывающую подборку таких оценок.

По данным социологов, даже в самый тяжелый кризисный период 2009 г. количество пессимистов в нашей стране составляло лишь 14\%, большинство же населения - 67\% - считало ситуацию тяжелой, но не катастрофической (Горшков, Петухов, 2015).

Экономический кризис 2014-2015 гг. привел к менее резким изменениям в умонастроениях граждан, чем в 2008-2009 гг. Осенью 2014 г. доля оптимистов в стране хотя и незначительно, но все же превышала долю пессимистов (соответственно 45 и 43\%). Начавшийся кризис на уровне страны в целом был воспринят россиянами относительно спокойно и отнюдь не качественно изменил их мироощущение. Это явление социологи объясняют тем, что либо наши сограждане постепенно привыкают к кризисам, либо масштаб воздействия на них кризиса 2014-2015 гг. был меньшим, чем в кризисные периоды 1998-1999 и 2008-2009 гг.

Социально-психологический климат в стране был не так плох, как этого следовало ожидать, исходя из опыта 1998 и 2008 гг. Так, оценивая социальнопсихологическое состояние окружающих людей, в 2014 г. 42\% россиян, в 2015 г. 36\% оценили его как позитивное - эмоциональный подъем, спокойствие, уравновешенность, а как негативное - безразличие, апатия, тревога, раздраженность, озлобленность, агрессия - в 2014 г. 58\%, в 2015 г. - 64\%. При этом из негативных социально-психологических состояний преобладала тревога (36\%). Таким образом, делают выводы авторы исследования, кризис негативно повлиял на настроения россиян, однако, во-первых, не очень сильно, вовторых, вызвал при этом вовсе не стремление «идти на баррикады» (что происходит, когда населению, как кажется, терять уже нечего), а более прозаическое чувство тревоги.

Динамика оценок нашими согражданами своего личного социально-психологического состояния выглядит следующим образом: позитивное состояние - 
эмоциональный подъем, спокойствие, уравновешенность констатировали в 1998 г. $11 \%$, в 1998 г. - 14\%, в 2000 г. $-20 \%$, в 2001 г. $-33 \%$, в 2002 г. - 34\%, в 2009 г. - 53\%, в 2013 г. - 63\%, в 2014 г. - 54\%, в 2015 г. - 49\%, а негативное социально-психологическое состояние - безразличие, апатия, подавленность, тревога, страх, раздраженность, озлобленность, агрессия - в 1998 г. 89\%, в 1999 г. $-86 \%$, в 2000 г. - 80\%, в 2001 г. - 67\%, в 2002 г. - 66\%, в 2009 г. 47\%, в 2013 г. - 37\%, в 2014 г. - 46\%, в 2015 г. - 51\% (Там же). Таким образом, налицо позитивная динамика личного социально-психологического состояния наших сограждан с 1998 по 2014 г., лишь в 2015 г. сменившаяся на негативную, при том весьма умеренную. 2015 г. продемонстрировал некоторое продолжение негативной динамики: позитивное личное социально-психологическое состояние отметили 47\%, а негативное - 53\%. При этом существенную динамику обнаружила только одна негативная позиция: чувства безразличия, апатии и подавленности стали проявляться в два раза чаще. Хуже обстояло дело с оценкой россиянами социально-психологического состояния своего окружения, которое в 2016 г. позитивно оценили только треть опрошенных, причем более половины респондентов констатировали в этом окружении такие чувства, как тревога, раздраженность, озлобленность и агрессия. Полученные данные социологи резюмируют выводом о том, что весной 2016 г. социальное самочувствие россиян было довольно мрачным (Горшков, Петухов, 2016).

При этом обнаружилась тенденция к более позитивной оценке личного социально-психологического состояния по сравнению с оценкой социальнопсихологического состояния окружающих и ситуации в стране в целом, что воспроизводит выявляемый во многих социально-психологических исследованиях феномен, не имеющий простого объяснения.

Явный психологический смысл имеет и оценка нашими согражданами социальной напряженности в нашем обществе. Сочли, что эта напряженность существенно или немного снижается, 21\% в 2008 г., 4\% в 2009 г. и 21\% в 2015 г., что она существенно или немного возрастает, $57 \%$ в 2008 г., $78 \%$ в 2009 г. и 64\% в 2015 г., что она остается без изменений, 32,1\% в 2008 г., 13,1\% в 2009 г. и 15\% в 2015 г. Как видим, здесь динамика не простая и не однонаправленная (Горшков, Петухов, 2015).

В 2013 г. наиболее оптимистические чувства как в восприятии ситуации в стране в целом, так и в личном социально-психологическом состоянии наблюдались у жителей мегаполисов, что, как отмечают авторы исследования, типично для стран догоняющего развития, где крупные города, в первую очередь столицы, являются средоточием экономической жизни (добавим, что в России различия в уровне жизни города и деревни существенно бо́льшие, чем в большинстве европейских стран). Но при этом крупные города первыми принимают на себя последствия экономических кризисов и к тому же горожане вообще более критичны. Именно у них произошло резкое снижение вычисляемого социологами индекса спокойствия как на уровне оценки ситуации в стране - на 14 баллов, так и на личном уровне - на 20 баллов, т.е. наши горожане и более оптимистичны (что естественно, поскольку они живут в целом 
лучше), но в то же время и более возбудимы, чем сельские жители (что тоже естественно с учетом большей нервозности городской жизни).

Представляет естественный психологический интерес и вопрос о динамике психологических качеств россиян. Как показывают опросы, сами россияне считают, что человеческие качества их соотечественников изменились за постсоветский период не в лучшую сторону. Отвечая на вопрос «Как, на ваш взгляд, изменились люди и отношения между ними за последние 10-15 лет?», они констатировали резкое снижение таких качеств, как доброжелательность, душевность, искренность, бескорыстие, честность, ослабление которых отметили 59-61\% опрошенных. При этом бо́льшая часть респондентов отметили рост агрессивности и цинизма. В то же время сравнение результатов опросов, проведенных в 2012 и 2015 гг., продемонстрировало, что в этот период наметилась тенденция к усилению позитивных и ослаблению негативных качеств, т.е. в последнее время наблюдается утешительная динамика.

Относительно деловых качеств россиян, таких как активность, целеустремленность, инициативность, обнаружился разброс оценок: 33\% считают, что за последние 10-15 лет они усилились, и почти столько же - 32\% - что они ослабли, и это противоречит расхожему представлению о том, что деловые качества россиян однозначно нарастают: очевидно, у кого-то они нарастают, у кого-то, особенно у тех, кто не вписался в наш специфический вариант рыночной экономики,- снижаются.

А вот в отношении таких качеств, как образованность, способность к сотрудничеству, трудолюбие, большинство респондентов констатируют либо отрицательную динамику, либо отсутствие изменений. Причем в данном плане и в период 2012-2015 гг. наблюдается негативная динамика.

Похожую динамику демонстрируют качества, которые авторы исследования относят к категории социальных, но которые при этом имеют и ярко выраженную психологическую составляющую. Большинство опрошенных констатируют снижение за последние 10-15 лет уважения к старшим и к женщинам, верности своим товарищам, доверия друг к другу, ответственности за то, что происходит вокруг, патриотизма, хотя и в этом плане сравнение 2012 и 2015 гг. демонстрирует позитивную тенденцию (Горшков, Петухов, 2015).

Эти результаты в сочетании с приведенными выше данными о динамике психологического состояния россиян демонстрируют, что психологическая адаптация россиян к новым условиям жизни в стране происходит, но ценой изменения психологического облика, в котором такие его традиционные атрибуты, как доброжелательность, душевность, искренность, бескорыстие, честность, постепенно стираются, вытесняемые такими качествами, как агрессивность и цинизм. Как пишет А.Н. Шаров, «Наблюдаемый период в развитии современного российского общества можно охарактеризовать как время достаточно высокой адаптивности населения к сложившейся в обществе ситуации, но также и как время напряженных ожиданий и опасений, обусловленных как сравнительно низким уровнем жизни основной массы населения страны, так и ощущением “ненадежности” человеческого существования в этих условиях» (Шаров, 2014, с. 121). 
Данные социологов демонстрируют, что после небольшого улучшения оценок ситуации в стране в конце 2015 г. весна 2016 г. принесла очередной всплеск массовых тревожных умонастроений. Количество россиян, оценивающих ситуацию в России как напряженную, достигло 65\%, а доля тех, кто воспринимает ее как спокойную и нормальную, снизилась до $18 \%$. В то же время количество так называемых «катастрофистов» осталось практически неизменным и составило 8\%. Позитивное же личное социально-психологическое состояние - эмоциональный подъем, спокойствие и уравновешенность - отметили 50\% (Горшков, Петухов, 2016).

Выявился и характерный для кризисных периодов социально-психологический феномен: люди воспринимают прошлое намного лучше, чем настоящее и будущее (Там же).

Данные опросов, проводимых психологами, в общем соответствуют социологическим данным. Так, опрос петербуржцев, проведенный в 2012 г., продемонстрировал, что две трети опрошенных либо полностью удовлетворены, либо скорее удовлетворены, чем не удовлетворены своей жизнью, а доля полностью неудовлетворенных составила лишь 6.8\% (Шаров, 2014). 83.6\% опрошенных либо уверены, что с ними и их близкими и в будущем все будет хорошо, и испытывают лишь некоторую, но весьма незначительную тревогу за будущее. При этом ожидание крупных неприятностей, страх перед будущим испытывают 15.9\% петербуржцев, что, впрочем, тоже немало (Там же).

В целом же психологи обычно дают довольно негативные характеристики социально-психологической атмосферы нашего общества, правда, как правило, имея в виду не тенденции последних лет, а ситуацию, наблюдающуюся с начала постперестроечного периода. Они пишут о том, что «психопатологические явления общественного и индивидуального сознания значительно усилились в постперестроечный период в связи с массированным давлением ценностей и норм, не совместимых с ее (России.- А.Ю.) традиционными архетипами» (Зобов и др., 2014, с. 237), «отмечается повышение напряженности в семейных отношениях, ухудшение взаимоотношений между поколениями, разрыв семейных связей, дефицит эмоциональной близости в семье, нарастание взаимного равнодушия, рост конфликтогенности и криминогенности семейной среды» (Самсонова, 2014, с. 164), «социальная среда сегодня агрессивна, особенно в отношении молодого поколения. Огромное число факторов социального риска обрушиваются на молодежь с самого начала ее сознательной жизни» (Там же, с. 153) и т.п.

Психологи также считают, что наиболее тревожной тенденцией, особенно отчетливо проявляющейся среди российской молодежи, являются снижение коллективизма, традиционно считавшегося одной из главных характеристик российского менталитета, и, соответственно, повышение уровня индивидуализма, причем его наиболее асоциального варианта, характеризующегося ущемлением интересов других людей (Боенко, 2005).

Н.А. Журавлева на основе осуществленных ею эмпирических исследований также приходит к выводу о том, что у нашей молодежи происходит переориентация с общественных проблем на личные, коллективизм постепенно 
сменяется индивидуализмом, наблюдается преобладание материальных ценностей над духовными, возрастание значимости для личности денег сопровождается снижением в иерархии ценностных приоритетов ориентаций на творчество, познание, общение с друзьями и честность. А в иерархии ценностных приоритетов старших школьников снижается вес альтруистических ценностей - любви и чуткости (Журавлева, 2014). Эти данные получены на молодежных группах, но трудно не согласиться с тем, что «именно в молодежной среде формируется новый тип личности, который будет доминировать в будущем» (Там же, с. 185).

Можно, конечно, предположить - вслед за нашими так называемыми либералами, что наше общество просто становится другим, не таким, каким оно было традиционно, новые ценности и новые ценностные иерархии постепенно принимаются массовым сознанием, что не должно приводить к ухудшению психологического состояния нашего общества. Но, во-первых, одни его члены, особенно молодежь, органически принимают новые ценности, другие - не принимают, и у последних их внедрение, как и их принятие определенной частью общества, порождает негативные эмоции и ухудшает их психологическое состояние. Во-вторых, внедрение ценностей, противоречащих основным характеристикам российского менталитета, вызывает болезненные для общества процессы, негативно сказывающиеся на его психологическом состоянии, которое, в свою очередь, оказывает влияние на соматические процессы. Например, как пишет протоиерей Вадим Леонов, «Попытки как-либо вытеснить или подавить стыд с помощью развлечений, самооправдания, лжи и т.д. приводят к глубоким духовным травмам, влекущим различные психические и физиологические последствия (неврозы, фобии, бессонница, головные и сердечные боли и т.д.)» (Леонов, 2013, с. 156).

А психотерапевты отмечают, что в последнее время в общественном сознании намечается возврат синдрома 1990-х гг: пациенты часто обращаются с жалобами на тревожно-подавленное внутреннее состояние, значительное снижение работоспособности, утрату вкуса к жизни, рассеянность и т. п. (Зобов и др., 2014). Психотерапевты подчеркивают также такую характеристику современного общественного сознания россиян, как психическая диссоциация, т.е. разъединенность нормального целостного функционирования психики, ее неуравновешенность и перегруженность фрустрационными состояниями, а также социальное отчуждение, потеря личностной идентичности, аутизм и одиночество (Там же).

Вместе с тем отмечаются и позитивные тенденции в динамике психологического состояния нашего общества, в частности снижение количества молодых россиян, которые испытывают беспокойство или страх перед будущим (Козлов, Утишева, 2005).

$* * *$

Полученные с помощью макропсихологического композитного индекса данные о динамике психологического состояния нашего общества соответствуют 
данным социологов, демонстрирующим его улучшение на протяжении длительного периода и некоторое ухудшение в последнее время, и расходятся с мнением психологов, дающих ему в основном негативные характеристики.

Строго говоря, и во втором случае нет противоречия. Во-первых, подсчитанный нами индекс характеризует динамику психологического состояния российского общества, в то время как психологи в своих оценках дают ему в основном статичную характеристику, часто вытекающую из результатов исследований, проведенных в прежние годы, и подчас имеющую «запаздывающий» характер. Во-вторых, психологи чаще характеризуют психологические качества наших сограждан и нравственную атмосферу в обществе, конечно, связанную с его психологическим состоянием, но непростой связью, особенно с теми характеристиками общества, которые учитываются композитным индексом. Что же касается данных социологов, то они, будучи основаны на результатах опросов, фиксируют несколько более раннее наступление тенденции к ухудшению - в 2015 г., нежели композитный индекс, основанный на показателях, имеющих более латентный характер.

Абстрагируясь от различий в конкретных оценках, следует в заключение подчеркнуть, что мы живем в достаточно напряженном, в том числе в психологическом плане, обществе, что вообще характерно для переходных социумов. Экономический кризис, противостояние с Западом, причем впервые в нашей истории с консолидированным Западом (в прежние годы мы противостояли одним западным странам, имея в союзниках другие), санкции, отсутствие внятной национальной идеи, огромное имущественное расслоение в современной России и другие факторы создают в нашем обществе очень напряженную ситуацию, которая неизбежно проецируется и на психологический уровень. Как показывают данные социологов, эта напряженность порождает у наших сограждан не рост протестных и революционных настроений, а возрастание тревожности, апатии, неуверенности в завтрашнем дне и другие негативные психологические состояния. Эти состояния, в свою очередь, неизбежно соматизируются, вызывая психические расстройства, нервно-психические заболевания, психосоматические болезни и т.п. При этом подобные явления носят запаздывающий характер по отношению к социальным процессам, являясь продуктами психологической аккумулящии реакции населения на них. В свою очередь, эти продукты обещают иметь социальный эффект, который может серьезно угрожать стабильности нашего общества.

Все это, разумеется, не должно порождать тотальный пессимизм, который тоже и в социальном и в психологическом плане разрушителен для общества, тем более что и отмеченные позитивные психологические тенденции достаточно существенны. Но адекватное понимание глубинных, не лежащих на поверхности, сложных социопсихосоматических процессов, неизбежной соматизации социальных явлений тоже необходимо для достижения одной из основных сощиальных целей всей отечественной социогуманитарной науки улучшения состояния нашего общества. 


\section{Литература}

Боенко, Н. И. (2005). Экономические реформы, ценности и российская полиментальность. В кн. В. Е. Семенов (ред.), Социальные и ментальные тендениии современного российского общества (с. 49). СПб.: Изд-во Санкт-Петербургского университета.

Горшков, М. К., Петухов, В. В. (ред.). (2015). Российское общество и вызовы времени. Книга вторая. М.: Весь мир.

Горшков, М. К., Петухов, В. В. (ред.). (2016). Российское общество и вызовы времени. Книга четвертая. М.: Весь мир.

Журавлев, А. Л., Юревич, А. В. (2016). Патриотизм как объект изучения психологической науки. Психологический журнал, 37(3), 88-98.

Журавлева, Н. А. (2014). Актуальные тенденции в ценностных ориентациях молодежи в современном российском обществе. В кн. А. Л. Журавлев, М. И. Воловикова, Т. В. Галкина (ред.), Психологическое здоровве личности и духовно-нравственные проблемы современного российского общества (с. 171-191). М.: Изд-во «Институт психологии РАН».

Зобов, Р. А., Матвеев, А. М., Сугакова, Л. И. (2014). Проблема здоровья человека в современном обществе (из истории методологического семинара НИИКСИ СПбГУ). В кн. В. Е. Семенов (ред.), Российское общество: проблемы социального согласия и развития (с. 233-240). СПб.: Изд-во Санкт-Петербургского университета.

Козлов, А. А., Утишева, Е. В. (2005). Проблематика социального здоровья и здорового образа жизни молодежи (на материале социологического исследования). В кн. В. Е. Семенов (ред.), Социальные и ментальные тенденции современного российского общества (с. 124-143). СПб.: Изд-во Санкт-Петербургского университета.

Леонов, В. (2013). Основы православной антропологии. М.: Изд-во Московской патриархии Русской Православной Церкви.

Самсонова, Т. И. (2014). Компетентность молодого поколения и будущее российского общества. В кн. В. Е. Семенов (ред.), Российское общество: проблемы социального согласия и развития (с. 150-166). СПб.: Изд-во Санкт-Петербургского университета.

Сироткина, И. Е., Смит, Р. (2006). «Психологическое общество»: к характеристике феномена. Психологический журнал, 27(1), 114-121.

Шаров, А. Н. (2014). Петербуржцы 2012: проблемы и перспективы. В кн. В. Е. Семенов (ред.), Российское общество: проблемы социального согласия и развития (с. 121-132). СПб.: Изд-во Санкт-Петербургского университета.

Юревич, А. В. (2014). Психология социальных явлений. М.: Изд-во «Институт психологии РАН».

Юревич Андрей Владиславович - заместитель директора, Институт психологии РАН, доктор психологических наук, член-корреспондент РАН.

Сфера научных интересов: макропсихология, социальная психология, методология психологии и науковедения, нравственно-психологическое состояние общества.

Контакты: av.yurevich@mail.ru 


\title{
Psychological State of Modern Russian Society: New Trends
}

\author{
A.V. Yurevich \\ ${ }^{a}$ Institute of Psychology of Russian Academy of Sciences, 13 build. 1, Yaroslavskaya str., Moscor, 129366, \\ Russian Federation
}

\begin{abstract}
The problem of psychological state of modern Russian society is in the focus of the analysis. For the purposes of the quantitative estimation of this state the author used a Composite Index elaborated by him and based on the integration of 6 primary indicators: Index of Mortality from the Diseases of the Nervous System and Sense Organs, Index of Homicide, Index of the Mental Illnesses, Index of the Family Stability, Index of the Social Orphanhood and Index of Suicide Mortality. The Index allowed to estimate quantitatively the dynamics of psychological state of Russian society from 1991 to 2016. The author analyses this dynamics in relation to social-economic and political events. The dynamics of primary indicators united by the Composite Index is also under analysis. Indices of Mortality from Homicide and Suicide reflect the mean trends of the Composite Index. The Index of the Diseases of Nervous System remained stable until 2012 and then showed the dramatic drop, while the Index of the Mental Illnesses remained relatively stable. Indices of the Family Stability and the Social Orphanhood showed complex tendencies, which can be explained by the general dynamics only partially. The latency of the Indices is discussed. The results of other investigations - sociological and psychological, characterizing the psychological state of modern Russian society and its dynamics are presented. The author comes to the conclusion about the existence of socio-psycho-somatic influence implied in the fact that social processes are reflected in the psychological state of citizens which in its turn has important somatic consequences.
\end{abstract}

Keywords: modern Russian society, psychological state, quantitative estimation, Composite index, dynamics, socio-psycho-somatic influence.

\section{References}

Boenko, N. I. (2005). Ekonomicheskie reformy, tsennosti i rossiiskaya polimental'nost' [Economic reforms, values and the Russian polymentality]. In V. E. Semenov (Ed.), Sotsial'nye i mental'nye tendentsii sovremennogo rossiiskogo obshchestva [Social and mental tendencies of the modern Russian society] (p. 49). Saint Petersburg: Saint Petersburg State University Press. (in Russian)

Gorshkov, M. K., \& Petukhov, V. V. (Eds.). (2015). Rossiiskoe obshchestvo i vyzovy vremeni [The Russian society and challenges of time] (Book 2). Moscow: Ves' mir. (in Russian)

Gorshkov, M. K., \& Petukhov, V. V. (Eds.). (2016). Rossiiskoe obshchestvo i vyzovy vremeni [The Russian society and challenges of time] (Book 4). Moscow: Ves' mir. (in Russian)

Kozlov, A. A., \& Utisheva, E. V. (2005). Problematika sotsial'nogo zdorov'ya i zdorovogo obraza zhizni molodezhi (na materiale sotsiologicheskogo issledovaniya) [The issues of social health and healthy life-style in youth (on the material of sociological study)]. In V. E. Semyonov (Ed.), Sotsial'nye i 
mental'nye tendentsii sovremennogo rossiiskogo obshchestra [Social and mental trends of the modern Russian society] (pp. 124-143). Saint Petersburg: Saint Petersburg State University Press. (in Russian)

Leonov, V. (2013). Osnovy pravoslavnoi antropologii [Foundations of the Russian Orthodox anthropology]. Moscow: Izdatel'stvo Moskovskoi patriarkhii Russkoi Pravoslavnoi Tserkvi. (in Russian)

Samsonova, T. I. (2014). Kompetentnost' molodogo pokoleniya i budushchee rossiiskogo obshchestva [Competence of the younger generation and the future of the Russian society]. In V. E. Semyonov (Ed.), Rossiiskoe obshchestvo: problemy sotsial'nogo soglasiya i razvitiya [The Russian society: problems of social accord and development] (pp. 150-166). Saint Petersburg: Saint Petersburg State University Press. (in Russian)

Sharov, A. N. (2014). Peterburzhtsy 2012: problemy i perspektivy [Petersburgers 2012: problems and perspectives]. In V. E. Semyonov (Ed.), Rossiiskoe obshchestvo: problemy sotsial'nogo soglasiya i razvitiya [The Russian society: problems of social accord and development] (pp. 121-132). Saint Petersburg: Saint Petersburg State University Press. (in Russian)

Sirotkina, I. E., \& Smith, R. (2006). "Psychological society": To the phenomenon characteristic's. Psikhologicheskii Zhurnal, 27(1), 114-121. (in Russian)

Yurevich, A. V. (2014). Psikhologiya sotsial'nykh yavlenii [The psychology of social phenomena]. Moscow: Institute of Psychology of RAS. (in Russian)

Zhuravlev, A. L., \& Yurevich, A. V. (2016). Patriotism as an object of psychological research. Psikhologicheskii Zhurnal, 37(3), 88-98. (in Russian)

Zhuravleva, N. A. (2014). Aktual'nye tendentsii v tsennostnykh orientatsiyakh molodezhi v sovremennom rossiiskom obshchestve [Current trends in value orientations of youth in the modern Russian society]. In A. L. Zhuravlev, M. I. Volovikova, \& T. V. Galkina (Eds.), Psikhologicheskoe zdorov'e lichnosti i dukhovno-nravstvennye problemy sovremennogo rossiiskogo obshchestva [Psychological health of personality and spiritual-moral problems in the modern Russian society] (pp. 171-191). Moscow: Institute of Psychology of RAS. (in Russian)

Zobov, R. A., Matveev, A. M., \& Sugakova, L. I. (2014). Problema zdorov'ya cheloveka v sovremennom obshchestve (iz istorii metodologicheskogo seminara NIIKSI SPbGU) [The problem of human health in the modern society (from the archives of methodological seminar of NIIKSI SPbGU)]. In V. E. Semyonov (Ed.), Rossiiskoe obshchestvo: problemy sotsial'nogo soglasiya i razvitiya [The Russian society: problems of social accord and development] (pp. 233-240). Saint Petersburg: Saint Petersburg State University Press. (in Russian)

Andrey V. Yurevich - Deputy Director of the Institute of Psychology of the Russian Academy of Sciences, Corresponding Member of the Russian Academy of Sciences, D.Sc., professor.

Research area: macropsychology, social psychology, methodology of psychology, moral and psychological state of modern society.

E-mail: av.yurevich@mail.ru 


\title{
EVIDENCE-BASED INTERVENTIONS FOR ASD: A FOCUS ON APPLIED BEHAVIOR ANALYSIS (ABA) INTERVENTIONS
}

\author{
E.L. GRIGORENKO ${ }^{\mathrm{a}, \mathrm{b}}$, S. TORRES ${ }^{\mathrm{b}}$, E.I. LEBEDEVA ${ }^{\mathrm{c}, \mathrm{d}}$, Y.A. BONDAR ${ }^{\mathrm{d}, \mathrm{e}}$ \\ ${ }^{a}$ St. Petersburg State University, $7 / 9$ University Embankment, St. Petersburg, 199034, Russian Federation \\ ${ }^{b}$ University of Houston, 4800 Calhoun Rd, Houston, TX 77004, USA \\ ${ }^{\circ}$ Institute of Psychology, Russian Academy of Sciences, 13/1 Yaroslavskaya Str., Moscow, 129366, \\ Russian Federation \\ ${ }^{d}$ Association of Non-profit Organizations Created by Parents with Autism Spectrum Disorders "Autism \\ Regions", 90 Dubininskaya Str., Moscow, 115093, Russian Federation \\ ${ }^{e}$ Novosibirsk State University, 2 Pirogova Str., Novosibirsk, 630090, Russian Federation
}

\begin{abstract}
Given the explosion in published psychological and educational interventions for autism spectrum disorder (ASD) over the past several years, this review highlights the latest trends for children with complex learning and developmental needs. Recent efforts in intervention research focus on meeting standards of scientific evidence and emphasize the importance of strict adherence to the principles of high quality research and evidence-based practice. According to recent systematic reviews, all evidence-based comprehensive intervention programs for children with ASD are based to some extent on the scientific discipline of Applied Behavior Analysis (ABA). Such intensive behavioral interventions have the power to improve the trajectory of development of a child with ASD. In particular, meta-analytical studies have demonstrated substantial improvement in IQ scores and adaptive behavior in children receiving early intensive ABAbased comprehensive interventions. Moreover, the majority of evidence-based focused interventions for ASD are either ABA-based or are included in ABA-based comprehensive intervention programs. There is a growing interest in modular interventions, which allow a high-degree of individualization for each child with ASD, while meeting the standards of evidence-based practice. An uptick in the number of rigorous evaluations of different interventions conducted in real-world settings with outcomes focused on core deficits in ASD augurs well for wide dissemination and implementation by qualified nonspecialists in the community.
\end{abstract}

Keywords: autism spectrum disorder, behavioral interventions, applied behavior analysis, evidence-based interventions.

Autism spectrum disorder (ASD) is a lifespan developmental disorder that manifests within the first three years of life primarily through difficulties in social communication and social interaction, and the presence of focused repetitive, restrictive or stereotyped behaviors, interests, and activities (APA, 2013). This disorder is characterized by striking heterogeneity both in its presentation (i.e., the

Preparation of this article was supported by the RFBR (award № 17-29-02384, PI: Grigorenko) and the Way Out Foundation. 
variability in levels of language, intellectual functioning, and presence of problematic behaviors) and etiology (i.e., the similarity in autistic features among many disorders of different causes).

The prevalence rate of ASD has surged since over 70 years ago, when the disorders were first described by Kanner (1943) and Asperger (Frith, 1991). Although the reasons for this increase remain unclear, it is partially attributable to the improvement in and availability of diagnosis (Hertz-Picciotto \& Delwiche, 2009). In the United States (based on data from 11 different states) in 2014, one in 59 8-year olds were identified with an ASD, four times more boys than girls (https://www.cdc.gov/features/new-autism-data/index.html).

A cure for ASD has not been identified. ASD treatment requires an orchestrated effort from multiple care providers and needs to be highly individualized and multifaceted (Warren et al., 2011), including early and intensive behavioral strategies, tailored educational interventions, continued support through major life competencies and milestones, and therapies for better clinical outcomes. The cost for quality ASD treatment can be quite high; over the lifespan of an individual with ASD, expenses can go up to US $\$ 2.4$ million (\$2.4 million for a child with and $\$ 1.4$ million for a child without intellectual disability) per family (Buesche, Cidav, Knapp, \& Mandell, 2014). Moreover, as these estimates do not account for collateral effects of ASD, such as stress on caregivers and families, they may underrate the broader societal impact of these disorders.

\section{Evidence-based practices and ASD interventions}

Due in part to the devastating presentation of severe ASD and to effective parent and clinician advocacy, a wide range of interventions have been developed aimed at remediating and supporting individuals with ASD. For example, the USA alone has allocated more than $\$ 1.4$ billion for research on ASD, and a substantial chunk of this research has focused on interventions (IACC, 2017). The interventions in the field of ASD range widely from scientifically validated procedures to parent-developed self-help management approaches, to apparently charlatan and fad treatments (Freeman, 2007; Reichow, Doehring, Cicchetti, \& Volkmar, 2011). The confluence of rising pressure from consumers (i.e., individuals with ASD and their families), and the broad system-wide provider response (influenced by increasingly precise calculations of the financial and social costs associated with ASD), pushed the need for the development and appraisal of ASD interventions to the forefront of the field. The investment required accountability, thus the issue of identifying evidence-based interventions (EBI) for the treatment of ASD became central.

In high-income countries, where practitioners are highly regulated by licensure and professional organizations, a common standard is to base the selection of intervention practices on scientific evidence of efficacy (Suhrheinrich, Hall, Reed, Stahmer, \& Schreibman, 2014). This standard has arisen from the evidence-based medicine movement that emerged from England in the 1960s (Sackett, Rosenberg, Gray, Haynes, \& Richardson, 1996). One of many outcomes of this movement has 
been the establishment of the Cochrane Collaboration to host reviews of the literature about scientifically supported practices and interventions. This movement has impacted not only medicine, but other fields in which human beings undergo various types of treatments. Driven by this movement, in the 1990s, Division 12 (Society of Clinical Psychology) of the American Psychological Association established criteria for classifying intervention practices as "efficacious" or "probably efficacious," which provided a precedent for quantifying the amount and type of evidence needed to establish a psychosocial intervention practice as evidencebased (Chambless et al., 1996). Subsequently, other professional organizations such as the Council for Exceptional Children (Odom et al., 2004), the US National Association for School Psychology (Kratochwill \& Shernoff, 2004), and the American Speech and Hearing Association, have developed corresponding standards, establishing the criteria for the level of evidence needed for a practice to be called EBI. This is not the only typology: other researchers have distinguished between evidence-based programs and evidence-supported programs (Cook \& Cook, 2013); in many instances, including here, these terms are used interchangeably.

The EBI approach has changed the professional standards in all of the diagnosis-specific subfields of clinical psychology and aligned disciplines (e.g., education and social work), including the field of ASD. Prior to the 21st century, the identification of EBI for individuals with ASD was accomplished primarily by means of narrative reviews conducted by groups of researchers and practitioners or organizations (Wong et al., 2015). Although useful at that time, as they were the only means for carrying out evenhanded comparisons of various treatment approaches, such reviews did not rely on a standard process for searching the literature, a stringent review process that incorporated clear criteria for including or excluding studies, a systematic process for organizing the information into sets of practices, an established procedure for identifying treatment outcomes, and a statistical routine for evaluating the treatment-related effect sizes. Subjective evidence such as testimonials, anecdotes, and personal accounts were deemed not reliable.

The general field of research into EBI has developed substantially over the last three decades. There are now guidelines and standard instruments for evaluating treatment studies, and systematic and meta-analytic reviews are common. These changes have impacted and reshaped the field of ASD as well. Many traditional systematic review processes such as the Cochrane Collaborative relied primarily on dominant methodologies for evaluating interventions, namely a randomized experimental group design (also called randomized control trial or RCT). Whereas early systematic reviews of ASD interventions (Rogers, 1998) did not identify any RCT on psychological or behavioral interventions for ASD, a review conducted ten years later (Rogers \& Vismara, 2008) located five RCTs, and the next five years produced approximately 50 additional RCTs (Weitlauf et al., 2014). The pace of ASD-related intervention research reflects a coordinated investment of federal and private funding organizations that continues to accelerate rapidly (IACC, 2017).

Importantly, additional methodologies have been acknowledged as instrumental in systematic and meta-reviews. Thus, the Cochrane Collaborative previously 
excluded single case design (SCD) studies (Kratochwill \& Levin, 2014), omitting a vital experimental research methodology prevalent in the field of ASD. Now SCD is recognized as a valid scientific approach, representing and illuminating the major body of research literature on interventions for children and youth with ASD. There are explicit expectations that the intervention literature will follow the standards for transparent reporting of study procedures, such as the Consolidated Standards of Reporting Trials (CONSORT) Statement for RCT (Moher et al., 2010) and the Transparent Reporting of Evaluations with Nonrandomized Trials (TREND) Statement for quasi-experimental studies (Fuller, Pearson, Peters, \& Anderson, 2012).

Unfortunately, despite the massive research and practice effort that has unfolded over the last four decades, the field is still looking for a cure for ASD. Yet, there are multiple ASD interventions whose number and availability can be estimated by the sheer quantity of empirical publications (hundreds per year) and by the growing number of systematic- and meta-reviews of these publications; yet far from all of these interventions are deemed effective. When ASD interventions are described, two different types of treatment are distinguished, comprehensive and focused.

Comprehensive treatment models (CTM, comprehensive interventions) consist of a set of elements (interventions) developed within a particular conceptual framework and conceived to result in a broad learning or developmental impact on the core deficits of ASD (Wong et al., 2015). To illustrate, in 2010 there were 30 CTM programs operating within the USA (Odom, Boyd, Hall, \& Hume, 2010) that could be characterized roughly according to their organization (i.e., around a conceptual framework), operationalization (i.e., procedures manualized), intensity (i.e., substantial number of hours per week), longevity (i.e., occur across one or more years), and breadth of outcome focus (i.e., multiple outcomes targeted, such as communication, behavior, social competence). Examples of CTMs are the Lovaas model (Lovaas, 1987), the Early Start Denver Model (ESMD; Dawson et al., 2010), Learning Experiences and Alternate Program for Preschoolers and their Parents (LEAP; Strain \& Bovey, 2011), More than Words (Carter et al., 2011), Pivotal Response Treatment (PRT; Koegel \& Koegel, 2012), Treatment and Education of Autistic and Related Communication Handicapped Children (TEAACH; Mesibov, Shea, \& Schopler, 2004), Joint Attention, Symbolic Play, Engagement and Regulation (JASPER; Kasari et al., 2014) among others.

Focused interventions (FI) are designed to address a single (or a limited number of) skill(s) or goal(s) of a student with ASD (Odom, Collet-Klingenberg, Rogers, \& Hatton, 2010). FI tend to be defined operationally, target specific learner outcomes, and unfold over shorter time periods than CTMs, for as long as a specific outcome is achieved. FI are the construction blocks or modules of CTMs and educational programs for individuals with ASD. For example, an FI peer-mediated instruction intervention is a key component of the LEAP model. Examples of FI are the Picture Exchange Communication System, PECS (Bondy \& Frost, 2001); functional behavior assessment, $F B A$ (Didden et al., 1997); and the PEAK, Promoting the Emergence of Advanced Knowledge (Dixon et al., 2017). 
To navigate these interventions and appraise their efficacy, summative reviews are conducted that meet the requirements of the field of EBI. One early widelycited review of ASD interventions (Rogers, 1998) concluded that no ASD interventions at that point could be classified as EBI. A decade later, another influential review (Rogers \& Vismara, 2008) deemed ASD interventions as promising but preliminary; that review classified only one intervention as well established, none as probably efficacious, and three as possibly efficacious. One of the most recent reviews (Smith \& Iadarola, 2015) identified two interventions as well-established, three as probably efficacious, and five as possibly efficacious. The only intervention labeled as "well established" in 2008 was a comprehensive individual intervention based on scientifically established principles of applied behavior analysis, ABA (Smith, 2011). The two interventional approaches labeled as "well established" in 2015 were individual, comprehensive ABA-based and teacher-implemented, focused interventions based on a blend of ABA with developmental social-pragmatic (DSP) models, also called developmental, interactive, transactional, or interpersonal (Ingersoll, Dvortcsak, Whalen, \& Sikora, 2005).

All high-quality reviews of ASD interventions today consistently and unequivocally identify ABA-based interventions as EBI and the first-choice treatment for individuals with ASD (Maglione, Gans, Das, Timbie, \& Kasari, 2012; National Autism Center, 2015; National Professional Development Center, 2013; New York State Department of Health Bureau of Early Intervention, 2017; Weitlauf et al., 2014; Wong et al., 2013). These reviews are cumulative interpretations of the ASD intervention literature which, since the 1980s, has consistently shown that interventions utilizing ABA have been effective in decreasing problem behavior and promoting the acquisition of new skills in children with ASD. Thus, in 2014, the Agency for Healthcare Research and Quality published a systematic review of existing and new RCT and cohort studies, in which it was established that an ABAbased early intensive behavioral intervention (EIBI) delivered over an extended time frame leads to clinically and statistically significant gains in cognitive ability, language, and adaptive skills (Weitlauf et al., 2014). Notably, although not always rigorously conducted, comparative studies of various interventions also provide evidence that ABA-based interventions constitute the most effective approach available to treat ASD. As of today, studies have demonstrated the effectiveness of several EIBI programs based on the principles of ABA, specifically, the Lovaas model and ESDM. Moreover, comprehensive reviews have identified interventions that are not EBI and cannot be recommended, specifically, auditory integration therapy, developmentally-based individual difference relationship-based intervention (DIR)/Floortime, Social Communication, Emotional Regulation, and Transactional Support (SCERTS), sensory integration therapy, touch therapy, music therapy, hormones (corticotrophin [ACTH] and Secretin), vitamin therapies, and special diets (New York State Department of Health Bureau of Early Intervention, 2017). Some treatments - i.e., facilitated communication, bonding (attachment) therapies, holding therapy, and psychoanalysis - have been deemed to be quite harmful and are recommended to be avoided (Foxx, 2008; Smith, 1996). 
Of note is that empirically supported treatments for ASD have commonalities that, in the view of many investigators, can be regarded as a set of best practices that should always be incorporated into services offered to children with ASD (Iovannone, Dunlap, Huber, \& Kincaid, 2003). Specifically, for an ASD treatment to be efficacious, it should utilize: (1) individualized services and supports by making use of the particular interests and individual learning style of each child with ASD to increase engagement in activities through interventions such as reinforcement systems and the incorporation of preferred activities into intervention sessions; (2) systematic intervention planning by selecting goals and instructional procedures based on a data-based assessment of each child, monitoring progress, and troubleshooting as needed; (3) comprehensible, structured environments such as using visual schedules to help children with ASD anticipate transitions between activities and organized work spaces to facilitate task completion; (4) specific intervention content to address the impairments in social communication and the restricted, repetitive behaviors that define ASD; (5) a functional approach to problem behavior: assessing the function or purpose of the behavior and selecting intervention strategies based on this assessment; and (6) family involvement to promote consistency between home and the intervention setting, take advantage of the family's knowledge of the child with ASD, and overcome difficulties that children with ASD are likely to have in transferring information from one setting to another.

\section{ABA as a guiding principle of ASD interventions}

The fundamental premise of all forms of ABA as a theoretical model is that for learning to occur three components are necessary. First, a stimulus must be present to cue the child's response (antecedent). Second, the child should respond by demonstrating a behavior. Third, there should be a consequence that will increase (reinforce) or decrease (punish) the future frequency of that behavior (Skinner, 1938). Skinner, whose work formed the foundation of ABA, demonstrated that in a carefully constructed environmental context, behaviors that produce favorable outcomes will continue to occur through the process of reinforcement and those behaviors that do not produce favorable consequences will decrease over time, or be extinguished. His antecedent-behavior-consequence framework is used to teach a range of skills (e.g., imitation, communication and social skills) that are deemed essential for further learning and development. Operant procedures used to establish new responses include shaping, prompting, extinction, reinforcement, modeling, among others. It is important to state that the principles and procedures of ABA have been used to treat a wide variety of behavior aberrations such as academic delays and addiction (Fisher, Piazza, \& Roane, 2011).

It has been observed that the first publication demonstrating the efficacy of Skinner's theory (1938) with children with ASD appeared in the early 1960s (Wolf, Risley, \& Mees, 1964). Yet, active interest in ABA-based interventions was ignited only in the 80 s by a landmark study in which one-half of the patients assigned to treatment were able to be placed in a neurotypical classroom and complete first grade (Lovaas, 1987). This study, conducted within the UCLA-Young 
Autism Project, utilized an intensive version of ABA-based treatment for ASD (Lovaas model), which is commonly referred to as EIBI. As originally conceived, EIBI is a comprehensive treatment model delivered 5-7 days per week, several hours per day for up to 25-40 hours per week (Myers \& Johnson, 2007). In its typical presentation, the treatment is initiated in a one-to-one format with a focus on the elimination of atypical behavior and the establishment of learning skills. Later, the treatment may become more group oriented and less structured while focusing on more complex cognitive and social skills (Smith \& Iadarola, 2015). In Lovaas's version, the EIBI model relied heavily on the discrete trial training (DTT) technique, which focuses on teaching skills in a repeated and brief fashion with specific instruction (the "discriminative stimulus") while minimizing extraneous details, thereby making the instruction "discrete." Correct responses are reinforced through various reinforcers, including but not limited to praise, whereas incorrect responses do not produce such positive reaction or are corrected while repeating the instruction. Importantly, DTT assumes an ongoing data collection and data analysis. The data are collected on a trial-by-trial basis or on a subset of trials, and are used to determine the child's rate of progress and whether procedural modifications are warranted. As children progress in skill development, this model typically is applied for a shorter duration - e.g., 15 hours per week - to address more complex social or other behavior - e.g., perspective taking.

Since the early versions of ABA-based treatment of ASD, the field of ABAbased research and practice has greatly expanded; behaviorally based interventions are now utilized to address a wide range of core symptoms of ASD, as well as challenging behaviors and comorbid conditions. ABA describes fundamental principles of the process that encompasses a field of study and is not just a single treatment for ASD. Thus, today ABA-/behavior-based interventions encompass a large number of methods and procedures. Yet, they are often grouped together (although they vary markedly in their objectives, content, structure, and effectiveness) by inexperienced consumers (researchers, practitioners, and parents) who are not very familiar with the multiplicity of diverse applications of ABA to the treatment of ASD.

Traditional ABA-based interventions are aimed to elicit behavioral modifications through highly intensive and structured trials, where adult-chosen stimuli are repeatedly presented to induce target behaviors in individuals with ASD, with correct responses reinforced (Vismara \& Rogers, 2010). More recently, advancements in ABA have led to more individualized and comprehensive treatments to target a wide range of adaptive behaviors that follow a more natural and normal developmental sequence (Thompson, 2013; Virués-Ortega, 2010).

In general, children who show behavior problems and skill deficits in multiple areas are candidates for comprehensive (immersive) treatments that might be conducted at high intensity in an effort to address the core symptoms and behavioral correlates of ASD through the implementation of a comprehensive intervention. Children who have relatively mild forms of ASD might be candidates for more timelimited or focused interventions. Practitioners can either adopt a CTM (again, many of which use specific FI) or build an individualized program combining multiple FI; 
the latter appears to be more popular (Bernstein, Chorpita, Daleiden, Ebesutani, \& Rosenblatt, 2015; Kasari, 2015). Below we provide selected illustrations of comprehensive and focused ASD treatments and discuss evidence of their effectiveness for treating ASD.

\section{Effectiveness of ABA-based interventions}

The effectiveness of ABA-based interventions in their various incarnations has been the subject of numerous meta-analytic studies (Eldevik et al., 2009, 2010; Estes et al., 2015; Kuppens \& Onghena, 2012; Makrygianni, Gena, Katoudi, \& Galanis, 2018; Makrygianni \& Reed, 2010; Peters-Scheffer, Didden, Korzilius, \& Sturmey, 2011; Reichow, Barton, Boyd, \& Hume, 2012; Reichow \& Wolery, 2008; Spreckley \& Boyd, 2009; Virués-Ortega, 2010). These studies vary in the interventions evaluated (CTM, FI or others), the designs used (RCT, SCD or other), the samples ascertained (age and diagnosis severity), and outcomes studied (core or associated features of ASD). This diversity leads to the challenge of evaluating the degree of their efficacy and the parameters that may contribute most to their effectiveness (Makrygianni et al., 2018). Yet, the field arrives to the same conclusion over and over again: there is unequivocal evidence for ABA-based interventions as an effective, and at this time first-choice, treatment for children with ASD.

Where there are equivocal findings is the precision of the estimates with which the global treatment effectiveness of the ABA family of interventions is translated into increases or improvement (in IQ scores, language skills, and adaptive behavior), and how it is translated into decreases and extinction (in autism-related symptomatology and/or symptom intensity, in the need for support during school inclusion, and in challenging behavior). To illustrate, Lovaas (1987) reported that $47 \%$ of the children with ASD who received long-term ABA-based comprehensive interventions achieved levels of normal intellectual and educational functioning as compared to only $2 \%$ of those children with ASD in a control group. Early metaanalyses have found similar improvement rates for children in ABA-based interventions as compared to those in control groups (Eldevik et al., 2009; Peters-Scheffer et al., 2011). A more recent (Reichow et al., 2012) meta-analysis presented an average effect size of $\mathrm{g}=0.69$ for adaptive behavior, $\mathrm{g}=0.76$ for IQ, $\mathrm{g}=0.76$ for communication skills, $\mathrm{g}=0.42$ for socialization, and $\mathrm{g}=0.55$ for daily living skills. The most recent meta-analysis (Makrygianni et al., 2018) indicated that ABA-based comprehensive programs are very effective in improving intellectual abilities ( $g=0.740)$; moderately to very effective in improving communication skills $(g=0.650)$, expressive-language skills $(g=0.742)$ and receptive-language skills $(g=0.597)$; moderately effective in improving IQ, indicated by non-verbal tests $(g=0.463)$, adaptive behavior (in total) $(g=0.422)$, and socialization $(\mathrm{g}=0.444)$; and had low effectiveness in improving daily living skills $(\mathrm{g}=0.138)$. Based on these figures, the collective effectiveness of the family of ABA-based interventions is moderate to high.

These impressive results have made an important impact on healthcare in the USA. Many publicly funded early intervention and preschool programs now also 
offer ABA-based interventions (Simpson, Mundschenk, \& Heflin, 2011). Similar initiatives have taken place in Canada (Perry et al., 2008), the United Kingdom (Kendall et al., 2013), and elsewhere.

However, although both academic evidence and public opinion point to ABAbased EBI as the preferred line of treatment for ASD, there is substantial opposition to the utilization of ABA. The push for ABA-based interventions has met considerable resistance on a number of fronts, including educational and governmental agencies not wishing to pay for expensive individualized programs. There are also professionals opposing ABA-based EBI who are either unfamiliar with ASD, or have philosophical perspectives antithetical to ABA, or who carry agendas that involve the promotion of competing approaches (Metz, Mulick, \& Butter, 2005; Smith, 2005).

Families of children with ASD have the right to use, and have used, a variety of services to help their children (Thomas, Morrissey, \& McLaurin, 2007). There are reports in the literature that some parents are actively discouraged from obtaining ABA-based interventions (Grindle, Kovshoff, Hastings, \& Remington, 2009); this deterrence is driven typically by one or a combination of ignorance of the ABA literature, ill will, or financial interests. Importantly, when parents themselves are surveyed, they project positive attitudes regarding the usage of ABA-based interventions in the treatment of their children. Thus, when parents of children who graduated from ESDM were asked to evaluate the program, they rated their experiences with ESDM positively and rated it as socially-valid (Ogilvie \& McCrudden, 2017). Similarly, parents of children treated with a variety of homebased ABA-based programs highlighted the overwhelmingly positive impact the interventions had on their children and deemed these interventions as sociallyvalid. The concept of social validity indicates how acceptable a given treatment (i.e., treatment acceptability) is to the population for which it was designed. A sociallyvalid intervention generally has a positive effectiveness and long-term trajectory.

Thirty-some years after the work of the UCLA Young Autism Project, the children are now adults. There are now studies on optimal outcomes of ASD in adulthood, since ASD is a life-long developmental disorder; that is, approximately $5-18 \%$ of individuals with an early ASD diagnosis are projected to, by adolescence (Helt et al., 2008), have no symptoms of ASD, and indeed to be behaviorally indistinguishable from their peers with a history of typical development. It has been documented that optimal outcome individuals generally receive earlier and more intense interventions based on ABA (Orinstein et al., 2014). Given the evidence in the literature on ASD, depriving or unjustifiably limiting exposure to high-quality ABA-based programs substantially lowers the chances of children with ASD reaching optimal outcomes in adulthood.

An important feature of intervention research is that evidence-based practice is a dynamic, not static, concept. The intervention literature is highly active and formulates new questions and challenges for researchers in an ongoing fashion. One such challenge in the field of developmental disorders in general and ASD in particular is the challenge of "non-responders," that is, children, who do not respond to EBI, regardless of how effective it has been shown to be in research studies. The 
dearth of information about the mediators and moderators that differentiate children's responses to EBI is widely acknowledged in the field, and there is a need for studies that establish guidelines for the prediction and monitoring of how an individual child with ASD will respond and is responding to a particular treatment. Such guidelines are especially important for CTM, given the extensive commitment of time and resources that these interventions entail (Smith \& Iadarola, 2015). There are already developments with regard to monitoring specific benchmarks deemed to be informative in determining whether a given intervention is progressing as intended. Moreover, there are suggestions for remedial strategies to consider when the intervention is not progressing (Ferraioli, Hughes, \& Smith, 2005). The greater the palette of EBI, the higher the chance of a "match" between a particular child with ASD and a particular EBI that is beneficial for that particular child.

There is a growing body of longitudinal analyses that are illuminating how child and family characteristics influence the course (i.e. initiation, continuation, and adherence) of ABA-based interventions (Kasari, 2015). Among the most commonly named child characteristics that matter, cognitive functioning, age at intervention entry, and social engagement are mentioned. Yet, the available information on child characteristics differentiating treatment outcome is limited.

It is also important to note that families differentially engage with treatment (Croen, Shankute, Davignon, Massolo, \& Yoshida, 2017). For example, among 293 insured children referred for ABA-based EBI, 23\% never initiated treatment. Among those initiating treatment, $31 \%$ discontinued treatment within 1 year of treatment initiation, and only $15 \%$ received $80 \%$ or more of the recommended treatment hours. Among positive predictors associated with treatment engagement were younger age at referral to treatment, private health insurance, and receiving more than 10 hours per week of EBI. Among negative predictors associated with treatment discontinuation were co-occurring psychiatric and medical conditions. Therefore, in helping the family select and implement EBI, it is essential to consider both child and family characteristics and assist families in adhering to the conditions of the intervention that are essential for its success.

\section{Conclusion}

In summary, ABA-based EIBI are the only evidence-based approach to providing comprehensive, individualized interventions for children with ASD. Such interventions have the power to alter the ASD trajectory of development. Importantly, the majority of evidence-based, focused interventions are either ABAbased or are included in ABA-based EIBI. There are factors that determine the resulting effectiveness of EIBI. Among such factors are the mode of EIBI delivery (where and by whom), the length of EIBI, and group (e.g., gender and ethnicity) and individual (e.g., general cognitive functioning) characteristics of children receiving EIBI. Moreover, there are multiple unanswered questions, such as the effectiveness of ABA-based interventions for adults with ASD and the role of ABA principles in educational and vocational training of individuals with ASD. 
The majority of adults with ASD do not live independently (Bruder, Kerins, Mazzarella, Sims, \& Stein, 2012), although outcomes are much better for those adults who received early diagnoses and appropriate treatment as children (Orinstein et al., 2014). Thus, early diagnosis and EBI starting as early as possible, within the first year of life, are imperative, as the need for better outcomes in adulthood are not only an increasing concern from a humanistic (Orinstein et al., 2014), but also from an economic perspective. This long-term perspective should encourage the professionals developing interventions for individuals with ASD to follow and respect the standard of providing the field with EBI. Short-term, to establish a network of effective support for individuals with ASD in Russia, what is crucial is the policy that guarantees that the federal support system utilizes only the most effective EBI.

Children and youth with ASD and their families should expect advances in intervention science to lead to better outcomes. This outlook to better outcomes is anchored in the necessity of translating scientific results into intervention practices that service providers may access, and provide professional development and support for implementing the practices with fidelity. It is important to acknowledge that the quickly growing field of implementation science in developmental disorders in general and ASD in particular may provide the needed guidance for such a translational process. Moreover, professional development models for teachers and service providers working with children and youth with ASD have turned to incorporating an implementation science approach (Odom et al., 2015). Such a movement from science to practice is a clear challenge and also an important next step for the field. Similarly, educating the consumers of these interventions (i.e., parents, teachers, and therapists of individuals with ASD) about EBI practice is also a challenge that should shape consumer standards by rejecting interventions that are not substantiated by empirical evidence. Obtaining such evidence is hard work, but without it, interventions might harm, not heal.

\section{References}

APA. (2013). Diagnostic and statistical manual of mental disorders (5th ed.). Washington, DC: American Psychiatric Association.

Bernstein, A., Chorpita, B. F., Daleiden, E. L., Ebesutani, C. K., \& Rosenblatt, A. (2015). Building an evidence-informed service array: Considering evidence-based programs as well as their practice elements. Journal of Consulting and Clinical Psychology, 83, 1085-1096. doi:10.1037/ccp0000029

Bruder, M. B., Kerins, G., Mazzarella, C., Sims, J., \& Stein, N. L. (2012). Brief report: The medical care of adults with autism spectrum disorders: Identifying the needs. Journal of Autism and Developmental Disorders, 42, 2498-2904.

Buesche, A. V., Cidav, Z., Knapp, M., \& Mandell, D. S. (2014). Costs of autism spectrum disorders in the United Kingdom and the United States. JAMA Pediatrics, 168, 721-728.

Carter, A. S., Messinger, D. S., Stone, W. L., Celimli, S., Nahmias, A. S., \& Yoder, P. (2011). A randomized controlled trial of Hanen's 'More Than Words' in toddlers with early autism symptoms. Journal of Child Psychology and Psychiatry, 52, 741-752. doi:10.1111/j.1469-7610.2011.02395.x 
Chambless, D. L., Sanderson, W. C., Shoham, V., Johnson, S. B., Pope, K. S., Crits-Christoph, P., ... Woody, S. R. (1996). An update on empirically validated therapies. Clinical Psychologist, 49, 5-18.

Cook, B. G., \& Cook, S. C. (2013). Unraveling evidence-based practices in special education. Journal of Special Education, 47, 71-82. doi:10.1177/0022466911420877

Croen, L. A., Shankute, N., Davignon, M., Massolo, M. L., \& Yoshida, C. (2017). Demographic and clinical characteristics associated with engagement in behavioral health treatment among children with Autism Spectrum Disorders. Journal of Autism and Developmental Disorders, 47, 3347-3357. doi:10.1007/s10803-017-3247-5

Dawson, G., Rogers, S., Munson, J., Smith, M., Winter, J., Greenson, J., ... Varley, J. (2010). Randomized, controlled trial of an intervention for toddlers with autism: the Early Start Denver Model. Pediatrics, 125, e17-e23.

Eldevik, S., Hastings, R. P., Hughes, J. C., Jahr, E., Eikeseth, S., \& Cross, S. (2009). Meta-analysis of early intensive behavioral intervention for children with autism. Journal of Clinical Child and Adolescent Psychology, 38, 439-450.

Eldevik, S., Hastings, R. P., Hughes, J. C., Jahr, E., Eikeseth, S., \& Cross, S. (2010). Using participant data to extend the evidence base for intensive behavioral intervention for children with autism. American Journal of Intellectual and Developmental Disabilities, 115, 381-405.

Estes, A., Zwaigenbaum, L., Gu, H., St. John, T., Paterson, S., Elison, J. T., ... IBIS Network. (2015). Behavioral, cognitive, and adaptive development in infants with autism spectrum disorder in the first 2 years of life. Journal of Neurodevelopmental Disorders, 7, 24. doi:10.1186/s11689-015-9117-6

Ferraioli, S., Hughes, C., \& Smith, T. (2005). A model for problem solving in discrete trial training for children with autism. Journal of Early Intensive Behavioral Intervention, 2, 224-246.

Fisher, W. W., Piazza, C. C., \& Roane, H. S. (2011). Handbook of applied behavior analysis. New York: Guilford Press.

Foxx, R. M. (2008). Applied Behavior Analysis treatment of autism: The state of the art. Child and Adolescent Psychiatric Clinics of North America, 17, 821-834. doi:10.1016/j.chc.2008.06.007

Freeman, S. K. (2007). The complete guide to autism treatments. A parent's handbook: Make sure your child gets what works. Lynden, WA: SKF Books.

Frith, U. (Ed.). (1991). Autism and Asperger syndrome. Cambridge, UK: Cambridge University Press.

Fuller, T., Pearson, M., Peters, J. L., \& Anderson, R. (2012). Evaluating the impact and use of transparent reporting of evaluations with non-randomised designs (TREND) reporting guidelines. British Medical Journal Open, 2, e002073. doi:10.1136/bmjopen-2012-002073

Grindle, C. F., Kovshoff, H., Hastings, R. P., \& Remington, B. (2009). Parents' experiences of homebased applied behavior analysis programs for young children with autism. Journal of Autism and Developmental Disorders, 39, 42-56. doi:10.1007/s10803-008-0597-z

Helt, M., Kelley, E., Kinsbourne, M., Pandey, J., Boorstein, H., Herbert, M., \& Fein, D. (2008). Can children with autism recover? If so, how? Neuropsychology Reviews, 18, 339-366. doi:10.1007/s11065-008-9075-9

Hertz-Picciotto, I., \& Delwiche, L. (2009). The rise in autism and the role of age at diagnosis. Epidemiology, 20, 84-90.

IACC. (2017). IACC strategic plan for autism spectrum disorder (ASD) research. Washington, DC: Interagency Autism Coordinating Committee, U.S. Department of Health and Human Services.

Ingersoll, B., Dvortcsak, A., Whalen, C., \& Sikora, D. (2005). The effects of a developmental, socialpragmatic language intervention on rate of expressive language production in young children with 
autistic spectrum disorders. Focus on Autism and Other Developmental Disabilities, 20, 213-222. doi:10.1177/10883576050200040301

Iovannone, R., Dunlap, G., Huber, H., \& Kincaid, D. (2003). Effective educational practices for students with autism spectrum disorders. Focus on Autism and Other Developmental Disabilities, 18, 150-165. doi:10.1177=10883576030180030301

Kanner, L. (1943). Autistic disturbances of affective contact. Nervous Child, 2, 217-250.

Kasari, C. (2015). Update on behavioral interventions for autism and developmental disabilities. Current Opinion Neurology, 28, 124-129.

Kasari, C., Lawton, K., Shih, W., Barker, T. V., Landa, R., Lord, C., ... Senturk, D. (2014). Caregiver-mediated intervention for low-resourced preschoolers with autism: an RCT. Pediatrics, 134, e72-e79.

Kendall, T., Megnin-Viggars, O., Gould, N., Taylor, C., Burt, L. R., \& Baird, G. (2013). Management of autism in children and young people: summary of NICE and SCIE guidance. BMJ: British Medical Journal, 347, f4865. doi:10.1136/bmj.f4865

Koegel, R. L., \& Koegel, L. K. (2012). The PRT pocket guide. Baltimore, MD: Brookes.

Kratochwill, T. R., \& Levin, J. R. (2014). Single-case intervention research: Methodological and statistical advances. Washington, DC: American Psychological Association.

Kratochwill, T. R., \& Shernoff, E. S. (2004). Evidence-based practice: Promoting evidence-based interventions in school psychology. School Psychology Review, 33, 34-48.

Kuppens, S., \& Onghena, P. (2012). Sequential meta-analysis to determine the sufficiency of cumulative knowledge: The case of early intensive behavioral intervention for children with autism spectrum disorders. Research in Autism Spectrum Disorders, 6, 168-176. doi:10.1016/j.rasd.2011.04.002

Lovaas, O. I. (1987). Behavioral treatment and normal educational and intellectual functioning in young autistic children. Journal of Consulting and Clinical Psychology, 55, 3-9.

Maglione, M. A., Gans, D., Das, L., Timbie, J., \& Kasari, C. (2012). Nonmedical interventions for children with ASD: Recommended guidelines and further research needs. Pediatrics, 130, S169-S178. doi:10.1542/peds.2012-0900O

Makrygianni, M. K., Gena, A., Katoudi, S., \& Galanis, P. (2018). The effectiveness of applied behavior analytic interventions for children with Autism Spectrum Disorder: A meta-analytic study. Research in Autism Spectrum Disorders, 51, 18-31. doi:10.1016/j.rasd.2018.03.006

Makrygianni, M. K., \& Reed, P. (2010). A meta-analytic review of the effectiveness of behavioural early intervention programs for children with Autistic Spectrum Disorders. Research in Autism Spectrum Disorders, 4, 577-593. doi:10.1016/j.rasd.2010.01.014

Mesibov, G. B., Shea, V., \& Schopler, E. (2004). The TEACCH approach to Autism Spectrum Disorders. New York: Springer.

Metz, B., Mulick, J. A., \& Butter, E. M. (2005). Autism: a late 20th century fad magnet. In J. Jacobson, R. M. Foxx, \& J. A. Mulick (Eds.), Controversial therapies for developmental disabilities: fads, fashion, and science in professional practice (pp. 45-60). Mahwah, NJ: Lawrence Erlbaum.

Moher, D., Hopewell, S., Schulz, K. F., Montori, V., Gwtzsche, P. C., Devereaux, P. J., ... Altman, D. G. (2010). CONSORT 2010 explanation and elaboration: updated guidelines for reporting parallel group randomised trials. BMJ, 340. doi:10.1136/bmj.c869

Myers, S. M., \& Johnson, C. P. (2007). Council on children with disabilities. Management of children with autism. Pediatrics, 120, 1162-1182.

National Autism Center. (2015). Evidence-based practice and autism in the schools. Randolph, MA: Author.

National Professional Development Center. (2013). The NPDC on ASD and the National Standards Project. 
New York State Department of Health Bureau of Early Intervention. (2017). New York State Department of Health Clinical Practice Guideline on assessment and intervention services for young children (age 0-3) with Autism Spectrum Disorders (ASD). Retrieved from https://www.health.ny.gov/community/infants_children/early_intervention/autism/docs/report_recommendations_update.pdf

Odom, S. L., Boyd, B., Hall, L., \& Hume, K. (2010). Evaluation of comprehensive treatment models for individuals with autism spectrum disorders. Journal of Autism and Developmental Disorders, 40, 425-436. doi:10.1007/s10803-009-0825-1

Odom, S. L., Brantlinger, E., Gersten, R., Horner, R. D., Thompson, B., \& Harris, K. (2004). Quality indicators for research in special education and guidelines for evidence-based practices: Executive summary. Arlington, VA: Council for Exceptional Children Division for Research.

Odom, S. L., Collet-Klingenberg, L., Rogers, S., \& Hatton, D. (2010). Evidence-based practices for children and youth with autism spectrum disorders. Preventing School Failure, 54, 275-282. doi:10.1080/10459881003785506

Odom, S. L., Thompson, J. L., Hedges, S., Boyd, B. A., Dykstra, J. R., Duda, M. A., ... Bord, A. (2015). Technology-aided interventions and instruction for adolescents with Autism Spectrum Disorder. Journal of Autism and Developmental Disorders, 45, 3805-3819. doi:10.1007/s10803-014-2320-6

Ogilvie, E., \& McCrudden, M. T. (2017). Evaluating the social validity of the Early Start Denver Model: A convergent mixed methods study. Journal of Autism and Developmental Disorders, 47, 2899-2910. doi:10.1007/s10803-017-3214-1

Orinstein, A. J., Helt, M., Troyb, E., Tyson, K. E., Barton, M. L., Eigsti, I. M., ... Fein, D. A. (2014). Intervention for optimal outcome in children and adolescents with a history of autism. Journal of Development and Behavioral Pediatrics, 35, 247-256.

Perry, A., Cummings, A., Dunn Geier, J., Freeman, N. L., Hughes, S., LaRose, L., ... Williams, J. (2008). Effectiveness of intensive behavioral intervention in a large, community-based program. Research in Autism Spectrum Disorders, 2, 621-642. doi:10.1016/j.rasd.2008.01.002

Peters-Scheffer, N., Didden, R., Korzilius, H., \& Sturmey, P. (2011). A meta-analytic study on the effectiveness of comprehensive ABA-based early intervention programs for children with autism spectrum disorders. Research in Autism Spectrum Disorders, 5, 60-69.

Reichow, B., Barton, E. E., Boyd, B. A., \& Hume, K. (2012). Early intensive behavioral intervention (EIBI) for young children with autism spectrum disorders (ASD). Cochrane Database of Systematic Reviews, 10. doi:CD009260

Reichow, B., Doehring, P., Cicchetti, D. V., \& Volkmar, F. R. (2011). Evidence-based practices and treatments for children with autism. New York: Springer.

Reichow, B., \& Wolery, M. (2008). Comprehensive synthesis of early intensive behavioral interventions for young children with autism based on the UCLA Young Autism Project Model.Journal of Autism and Developmental Disorders, 39, 23-41. doi:10.1007/s10803-008-0596-0

Rogers, S. J. (1998). Neuropsychology of autism in young children and its implications for early intervention. Mental Retardation and Developmental Disabilities Research Revieres, 4, 104-112.

Rogers, S. J., \& Vismara, L. A. (2008). Evidence-based comprehensive treatments for early autism. Journal of Clinical Child and Adolescent Psychology, 37, 8-38. doi:10.1080=15374410701817808

Sackett, D. L., Rosenberg, W. M., Gray, J. M., Haynes, R. B., \& Richardson, W. S. (1996). Evidence-based medicine: What it is and what it isn't. British Medical Journal, 312, 71-72. doi:10.1136/bmj.312.7023.71

Simpson, R. L., Mundschenk, N. A., \& Heflin, L. J. (2011). Issues, policies, and recommendations for improving the education of learners with autism spectrum disorders. Journal of Disability Policy Studies, 22, 3-17. doi:10.1177/1044207310394850 
Skinner, B. F. (1938). The Behavior of organisms: An experimental analysis. New York: AppletonCentury.

Smith, T. (1996). Are other treatments effective? In C. Maurice, G. Green, \& S. C. Luce (Eds.), Behavioral intervention for young children with autism: a manual for parents and professionals (pp. 45-62). Austin, TX: Pro-Ed.

Smith, T. (2005). The appeal of unvalidated treatments. In J. Jacobson, R. M. Foxx, \& J. A. Mulick (Eds.), Controversial therapies for developmental disabilities: fads, fashion, and science in professional practice (pp. 45-60). Mahwah, NJ: Lawrence Erlbaum.

Smith, T. (2011). Applied behavior analysis and early intensive intervention. In D. G. Amaral, G. Dawson, \& D. H. Geschwind (Eds.), Autism spectrum disorders (pp. 1037-1055). New York: Oxford University Press.

Smith, T., \& Iadarola, S. (2015). Evidence base update for autism spectrum disorder.Journal of Clinical Child and Adolescent Psychology, 44, 897-922.

Spreckley, M., \& Boyd, R. (2009). Efficacy of applied behavioral intervention in preschool children with Autism for improving cognitive, language, and adaptive behavior: A systematic review and meta-analysis. The Journal of Pediatrics, 154, 338-344.

Strain, P. S., \& Bovey, E. (2011). Randomized, controlled trial of the LEAP model of early intervention for young children with autism spectrum disorders. Topics in Early Childhood Special Education, 313, 133-154. doi:10.1177/0271121411408740.

Suhrheinrich, J., Hall, L. J., Reed, S. R., Stahmer, A. C., \& Schreibman, L. (2014). Evidence based interventions in the classroom. In L. Wilkinson (Ed.), Autism spectrum disorder in children and adolescents: Evidence-based assessment and intervention in schools (pp. 151-172). Washington, DC: American Psychological Association.

Thomas, K. C., Morrissey, J. P., \& McLaurin, C. (2007). Use of autism-related services by families and children. Journal of Autism and Developmental Disorders, 37, 818-829. doi:10.1007/s10803-0060208-9

Thompson, T. (2013). Autism research and services for young children: history, progress and challenges. Journal of Applied Research in Intellectual Disabilities, 26, 81-107.

Virués-Ortega, J. (2010). Applied behavior analytic intervention for autism in early childhood: Metaanalysis, mega-regression and dose-response meta-analysis of multiple outcomes. Clinical Psychology Review, 30, 387-399.

Vismara, L. A., \& Rogers, S. J. (2010). Behavioral treatments in Autism Spectrum Disorder: What do we know? Annual Review of Clinical Psychology, 6, 447-468. doi:10.1146/annurev.clinpsy.121208.131151

Warren, Z., McPheeters, M. L., Sathe, N., Foss-Feig, J. H., Glasser, A., \& Veenstra-Vanderweele, J. (2011). A systematic review of early intensive intervention for autism spectrum disorders. Pediatrics, 127, e1303-e1311.

Weitlauf, A. S., McPheeters, M., Peters, B., Sathe, N., Travis, R., Aiello, R., ... Warren, Z. (2014). Therapies for children with Autism Spectrum Disorder: Behavioral interventions update (Publication No. EHC2013-09-0038.R1). Rockville, MD: AHRQ (US Agency for Healthcare Research and Quality).

Wolf, M., Risley, T. R., \& Mees, H. L. (1964). Applications of operant conditioning and procedures to the behavior problems of an autistic child. Behaviour Research and Therapy, 1, 305-312.

Wong, C., Odom, S. L., Hume, K., Cox, A. W., Fettig, A., Kucharczyk, S., \& Schultz, T. R. (2013). Evidence-based practices for children, youth, and young adults with Autism Spectrum Disorder. Chapel Hill, NC: The University of North Carolina, Frank Porter Graham Child Development Institute, Autism Evidence-Based Practice Review Group. 
Wong, C., Odom, S. L., Hume, K. A., Cox, A. W., Fettig, A., Kucharczyk, S., ... Schultz, T. R. (2015). Evidence-based practices for children, youth, and young adults with Autism Spectrum Disorder: A comprehensive review. Journal of Autism and Developmental Disorders, 45, 1951-1966. doi:10.1007/s10803-014-2351-z

Elena L. Grigorenko - Hugh Roy and Lillie Cranz Cullen Distinguished Professor, Department of Psychology, University of Houston; Research Certified Adjunct Professor, Departments of Pediatrics and Molecular and Human Genetics, Baylor College of Medicine; Leading Researcher, Saint Petersburg State University, Ph.D.

Research area: cognitive development, developmental disabilities, neuropsychiatric genetics.

E-mail: Elena.grigorenko@yale.edu

Stephanie Torres - Graduate Student, Department of Psychology, University of Houston.

Research area: child neuropsychology.

E-mail: sttorres91@gmail.com

Evgeniya I. Lebedeva - Senior Researcher, Institute of Psychology of Russian Academy of Sciences; Head of Scientific Department, Association of Non-profit Organizations Created by Parents of Children with Autism Spectrum Disorders "Autism Regions”, Ph.D.

Research area: autism spectrum disorder, cognitive development, theory of mind.

E-mail: evlebedeva@yandex.ru

Yevgeniy A. Bondar - Management Board Member, Association of Non-profit Organizations Created by Parents of Children with Autism Spectrum Disorders "Autism Regions"; Leading Research Fellow, Novosibirsk State University, Ph.D.

Research area: autism spectrum disorder, evidence-based practices, early intervention, applied behaviour analysis.

E-mail: bond@itam.nsc.ru

\title{
Вмешательства при РАС с доказанной эффективностью: акцент на вмешательствах, основанных на прикладном анализе поведения (ПАП)
}

\author{
Е.Л. Григоренко ${ }^{\mathrm{a}, \mathrm{b}}$, С. Торрес ${ }^{\mathrm{b}}$, Е.И. Лебедева ${ }^{\mathrm{c}, \mathrm{d}}$, Е.А. Бондарь ${ }^{\mathrm{d}, \mathrm{e}}$
}

\section{Резюме}

Настоящий обзор освещает последние тенденции в области психолого-педагогических вмешательств для детей с расстройствами аутистического спектра (РАC) с учетом стремительного роста числа публикаций по этой тематике в последние несколько лет. В настоящий момент внимание специалистов в области вмешательств при РАС сосредоточено на соблюдении стандартов научной доказательности и высоком качестве исследований. Согласно недавним систематическим обзорам, все комплексные программы вмешательства для детей с РАС с доказанной эффективностью в той или иной степени основаны на научной дисциплине прикладного анализа поведения (ПАП). Реализация таких интенсивных поведенческих программ улучшает траекторию развития ребенка с PAC. В частности, метааналитические исследования демонстрируют существенное 
улучшение показателей IQ и адаптивного поведения у детей, помощь которым оказывалась в рамках ранних интенсивных комплексных программ, основанных на ПАП. Более того, большинство целевых вмешательств с доказанной эффективностью для детей с РАС либо также основаны на ПАП, либо являются компонентами комплексных программ вмешательств, основанных на ПАП. В последнее время возрастает интерес к модульным вмешательствам, которые позволяют обеспечить высокую степень индивидуализации программы помощи для каждого ребенка с РАС, в то же время удовлетворяя стандартам научной доказательности. Рост числа строгих оценок эффективности различных вмешательств, применяемых в реальных неклинических условиях для компенсации основных дефицитов, связанных с РАС, создает адекватную базу для внедрения и широкого использования вмешательств с доказанной эффективностью в системе помощи людям с РАС, в том числе неспециалистами, прошедшими базовую подготовку.

Ключевые слова: расстройство аутистического спектра, поведенческие вмешательства, прикладной анализ поведения, вмешательства с доказанной эффективностью.

Григоренко Елена Леонидовна - профессор, факультет психологии, Хьюстонский университет; ведущий ученый, Лаборатория междисциплинарных исследований развития человека, Санкт-Петербургский государственный университет, доктор психологических наук, Ph.D.

Сфера научных интересов: когнитивное развитие, атипичные траектории развития, нейропсихиатрическая генетика.

Контакты: Elena.grigorenko@yale.edu

Торрес Стефани - аспирант, факультет психологии, Хьюстонский университет.

Сфера научных интересов: детская нейропсихология.

Контакты: sttorres91@gmail.com

Лебедева Евгения Игоревна - старший научный сотрудник, ФГБУН «Институт психологии РАН»; руководитель центра ответственности «Наука», Ассоциация некоммерческих организаций, созданных родителями детей с расстройствами аутистического спектра, «Аутизм-Регионы», кандидат психологических наук.

Сфера научных интересов: расстройство аутистического спектра, когнитивное развитие, модель психического.

Контакты: evlebedeva@yandex.ru

Бондарь Евгений Александрович - член правления, Ассоциация некоммерческих организаций, созданных родителями детей с расстройствами аутистического спектра, «АутизмРегионы»; ведущий научный сотрудник, Новосибирский государственный университет, кандидат физико-математических наук.

Сфера научных интересов: расстройство аутистического спектра, практики с доказанной эффективностью, раннее вмешательство, прикладной анализ поведения.

Контакты: bond@itam.nsc.ru 


\title{
A NON-DIALOGIC RELATION TO THE OTHER: REGRESSION OR OPPOSITION TO DIALOGICITY
}

\section{E.B. STAROVOYTENKO ${ }^{\mathrm{a}}$}

${ }^{a}$ National Research University Higher School of Economics, 20 Myasnitskaya Str., Moscowe, 101000, Russian Federation

\begin{abstract}
The study presented in this paper is focused on the development of theoretical models of the dialogic and non-dialogic nature of the personal relationship to the Other. Based on the philosophical and psychological research of the dialogue (M.M. Bakhtin, M. Buber, J. Sartre, E. Levinas, H.J.M. Hermans, T. Maranhao, M. Puchalska-Wasyl, F. Rivetti Barbo, T. Zittoun), the author emphasizes the involvement of the individual in various forms of activity that, due to personal efforts, acquire a dialogical character. The "personality's attitudes toward significances" stand out among these forms, including the relation to another significant person. The author develops an understanding of dialogue as a complete realization of the relation to the Other in the dimensions between-I-and-Other, I-in-Other, Other-in-I, and I-in-Self-with-Other. Non-dialogicity, which rarely happens to be the subject of psychological research, firstly can be defined as one of the possibilities for the formation of an attitude; secondly, as a regress of the dialogical attitude; thirdly, as a binary opposition present in the conscious plane, or "in the shade" of the dialogical dynamics of the attitude; fourthly, as a trend that conflicts with dialogicity in favour of the development of dialogue. Following the multilateral view on the genesis of dialogicity/non-dialogicity in the personality's relation to the Other, a number of theoretical models have been developed: a model of the dialogic attitude to the significance; models of the I in the context of a dialogical attitude; the existential model of regression in the dialogicity of the I-Other relation; a model of personal prerequisites of non-dialogicity in relation to the I-Other; a model of oppositions to dialogicity in the dimensions of the I-Other relation.
\end{abstract}

Keywords: personality, I, Other, relationship, reflection, dialogue, dialogicity, non-dialogicity, regression, opposition, hermeneutics, model, theory.

\section{Introduction}

In the modern humanities the problem of dialogue is explored in the context of theories of culture and language, consciousness and text, I and intersubject relations. In philosophical and psychological sciences (in particular, in the psychology of personality) the studies are focused on dialogues of individual consciousnesseibid.s, on the dialogicity of speech and individual cognition, dialogic communication and intrapersonal dialogue, dialogue with oneself and the dialogical I of personality (Bakhtin, 1986; Buber, 1993; Sartre, 1953; Levinas, 2006; 
Borisov, 1997; Kopiev, 1999; Florenskaya, 2001; Hermans, 2006-2007; Dimaggio, Salvatore, \& Hermans, 2003; Maranhao, 1990; Puchalska-Wasyl \& Oles, 2013; Rivetti Barbo, 1983; Zittoun, 2014). The entire psychological research of personal dialogue highlights the role of the Other (of many and individual people) that has various external and internal connections with an individual. One of the research tasks is to study the involvement of the Other in various forms of the activity of personality that acquire a dialogical nature (due to an individual's own efforts and the possibilities of the Other). However, among these forms little emphasis is placed on the "personality's attitudes toward significances" including the attitude to another significant person. We believe that an individual attitude to a significant Other and multidimensionally mediated by other people can either gain or not a dialogical character under conditions that are to be discovered in fundamentally new research.

This research, in our opinion, should interpret the experience of investigating the dialogue in philosophical sciences and cultural research, with the context of psychological ideas and facts relating to individual dialogicity taken into account. The research should put the I of personality in the focus of learning the dialogical attitude to the Other, reveal the non-dialogical nature of the attitude as an alternative way to implement it (as compared to the dialogue). The non-dialog nature, which rarely happens to be the subject of psychological research, firstly can be studied as one of the possibilities for the formation of an attitude; secondly, as a regress of the dialogical attitude; thirdly, as a binary opposition present in the conscious plane, or "in the shade" of the dialogical dynamics of the attitude; fourthly, as a trend that conflicts with dialogicity in favour of the development of dialogue.

Following the multilateral view on the genesis of non-dialogicity and relying on our previous studies, we propose a concept of dialogicity/non-dialogicity of the personality's attitude to the Other that was developed using the method of theoretical modeling.

\section{A model of the dialogic attitude to the significance.}

The attitude to the Other belongs to the broadest scope of phenomena, which are psychologically designated as attitudes of personality. As related to the development and achievement of maturity, the attitude of an individual is an integral form of conscious life aimed at the significance so that the potential of the individual and the significant can be released and implemented (Starovoytenko, 2015). Attitudes constitute the process of the mental and experiential life of an individual. They define its progress and are imbued in every moment of subjective living. In this respect they are considered to be life attitudes. The I of a person (with its potential for reflexivity and self-fulfillment) is a necessary source, subject and "derivative" of the attitude. At the same time the profound self-movement of life and the spiritual transcendence of the individual to higher levels of existence are translated in the attitude. 
The personality may connect with the significances through syntheses of the elements of the functional architectonics of the attitude. Those are the desire and experience, growth and contemplation, imprinting and remembering, thought and reflection, the intent to act and the action. The I (either explicitly or implicitly) is present in each of these elements and either reflexively or non-reflexively determines the integrity and continuity of the attitude.

The nature of significances and the architectonics enable a distinction of the attitude types using three groups of criteria: subject and content, structure and function, and value-based. In particular, the subject and content criterion defines a person's attitude to the world, to the Absolute, nature, culture, society, activity, values, other people, to individual people and to themselves. Each of these general attitudes is fulfilled in a variety of private attitudes that are oriented toward individual significances: toward specific Others, individual beings, communities, things, signs, activities, properties and ways of life of the Other, aspects of the I, etc. The structural and functional criterion is applied to distinguish emotional, sensory and sensuous, figurative, mental, intuitive, practical, and reflective attitudes. Religious, cognitive, ethical, aesthetic attitudes and the attitude towards oneself are distinguished according to the value criterion.

Diverse relationships are involved in the development and realization of each other; every relation in one's own existence provides for a multilateral co-presence of personality and significance; different relationships are combined by mutual multiplication of possibilities. For example, the attitude of the person to themselves in the aspect of appearance can be realized through developed emotional, imaginative, intuitive relationships and can be involved in the formation and potentiation of their general aesthetic relationship.

As life unfolds, the attitude to significance acquires multi-stage dynamics that is flexibly structured with elements of its architectonics. It has a conscious current action, the actualization of knowledge and meaning, the awareness of the "I can," the development of motivation, goal-setting, acts of choice, decision making, novel action and the evaluation of its results in terms of productivity, subjective satisfaction, as well as problematization, re-emphasis and changes in the meaning all mutually generated and transferred into each other (Ibid.). Semantic reemphasis determines the future active attitude of an individual to the significant in terms of possible - desired - purpose-oriented - chosen - achieved - fulfilled.

When a certain attitude is realized, the person consciously experiences an encounter with the significant; correlates himself or herself with it; puts it in relation to themselves; refers to the significant presented in themselves; refers to themselves as represented in it; refers to themselves in their connections with the significant. As an I, a person can reflectively relate to these moments of the attitude, develop their architectonics, find their unity thus achieving dialogicity in the interaction with the significant (Starovoytenko, 2017; Starovoytenko \& Derbeneva, 2017).

We believe that the attitude to the significant has to undergo a few stages in order to attain dialogicity. Those stages are the search and the discovery of a significance as an object corresponding to strong aspirations of the individual; an 
impression of the moment of meeting with the significant; the identification of own personality with the significance as coinciding with a desire; the establishment of a distance between themselves and the significance as "different;" entering into a real interaction with the significance; the awareness of oneself as truly interacting with the significance; a transfer of the significance and effects of the interaction with it in the subjective plan, therefore turning it into an "internal significance;" the person's search for "themselves" and their active contributions in the existence and structure of the significant; own "view of themselves" from the world of the significance; real actions fulfilled by the person towards the significant that stimulate the development of its internal "equivalent" and the awareness of personal presence in it; the interaction of the individual with their inner significance when personal presence in it is realized; the individual's view into themselves from the position of own inner interaction with the significance; the internal significance correlated with the real significance; the person's intention to develop and correlate the significance, self-in-significance and significance-in-self; finding and managing the person's contradictions in the external and internal interaction with the significance; the exit of the person into the world, beyond the boundaries of the established connection with the significant, where the being of the significance is largely unknown; the person's in-self generalization of conscious moments of own external and internal interaction with the significant; the returned autonomy to oneself and to the significance, the turn into self by the completion or renewal of the interaction with it; a new discovery of the significance in the world (Starovoytenko, 2015).

The stages described realized fully or partially, possessing continuity/gaps and harmony/conflict, can define a relatively completed cycle of the dialogical attitude of an individual to the significant. In a dialogue with a significance each stage and the attitude as a whole are performed in the measurements of the real interaction of a person with the significance ("between"), the personality-induced effects on the significance ("in-significant"), the influence of the significant experienced by a person as well as the occurring transformation ("in-person"), the self-aggregation of the measurements of an attitude ("in-self"), the individual's exits into the world as having become related to the significant ("in the world"). When an attitude progresses into a reflective plane, these measurements are transformed into "between-I-and-significant," "I-in-significant," “Significant-in-I,” “I-in-myselfwith-significant," "I-in-the-world-with-significant." In this complex multidimensional space of each attitude the personality, its I and the significant can have simultaneous and alternating objectness and subjectness with a dominating personal position of the subject.

An individual that finds itself in relation to the significant and fully realizes and multiplies its potential, in our opinion, should possess prerequisite properties determining the person's strong subjectness in the context of life. Numerous research into the subject of life shows that these properties include susceptibility to the world, the openness to subjective experience, the ability to organize the time of life, the sensitivity to the new, an intuition for destiny, intended purpose, the love of life, care towards others, commitment, initiative, intellectuality, maturity of 
the I, reflexivity, dialogue ability, higher feelings, creativity, productivity, resilience, satisfaction with life, life fulfillment, and a sense of life prospects. We believe that these properties constitute a stable resource and a "fixed" intrapersonal result of a dialogical attitude from the moment of capturing, accepting and mastering a significance, to the moment of an active mental and practical interaction with it, to the moment of experiencing and reflecting on own presence in the being of the significant, to the moment of understanding and reflecting the activity of a significance in own life, to the moment of selftransformation in the connection with the significant and to the moment of discovering new possibilities of the I and the significance in the world. Being realized in an attitude, the prerequisite properties contribute to the enhancement of its resource, both in terms of its development and in the aspect of the subject person acquiring effective methods of positioning in the world beyond the boundaries of this attitude.

A subject's property of "being the I" plays a leading role in the development and realization of the subject in relation to significance. The property can be considered as an integral of self-consciousness and a generalized effect of the personality's dialogue with oneself that ensure the person's self-positing in the world. Models of the I may be applied to justify the role of the property in the context of relationships. The models emphasize those forms or hypostases of the I that determine the self-being and interaction, reflection and self-sufficiency, cognition and creativity of an individual in relation to significant objects.

\section{Models of the I in the context of a dialogical attitude}

The first model proposed by V.A. Petrovsky (Petrovsky, 2013 consists in distinguishing a number of successive forms of the $\mathbf{I}$ that are considered as constituting continuous connections of the personality with oneself and the significance at all moments of attitudes.

The Pure I, or the individual being as such, contains in its potential the possibility of "relations" and the essential certainty of the conscious I.

The Existential I, or self, the nuclear "in-itself," which gains (through its own existence) the fulfillment and fullness in the world. In the self-movement of life, the I comprehends the significances and their possibilities, it finds "itself" on a profound level through them and in them with all the diversity of the modes of presence and in the ability to relate.

The Phenomenal I as a unity of the general "feeling of self" in its various hypostases: of the feeling of own indivisibility, integrity, continuity, oneness with oneself (I-autotelicity); self-contemplation, the perception of the factual givenness of "oneself" to oneself, the experience of self-belonging (I-self-sufficiency); sensual self-knowledge, the deduction of oneself from the "concealed," self-positing (selfrevelation); self-reliance, self-adherence, following oneself (I-self-worth). This is the I that in its reality for-itself can become directly relevant to the significance, enter into interaction with it, while preserving itself in the autonomy and freedom of realization. 
The Cogital I as an effect of the reflection of own hypostases and the knowledge acquired on the existence of unknown possibilities. It establishes and challenges the links between various aspects of the I, providing an experience of the self known by self, of self-coincidence, and own authenticity. It is the I that can mentally and imaginatively find itself in different dimensions of the relation to significance, while revealing its differences as one experiencing the impact of the significant reflected by the significant, having the significant in itself, affecting the significant, and existing self-in-itself-for-itself.

The True or Existential I as never coinciding with itself, as unable to identify with itself in reflection, as supposing and maintaining the boundaries between the I, the non-I and the I-another, as not identical to its individual hypostases, as preserving the mystery of the emergence of a given individual being and the impossibility of its full realization in the world. It is the I that in the context of any attitude to the significant is always redundant in comparison with which is consciously realized in impersonal and intrapersonal processes of the attitude, but that is also always not sufficient in comparison with the demands of new situations in which it meets with significance.

We developed the second model (Starovoytenko, 2013) to differentiate the hypostases of the I, with which the personality faces significance in various dimensions of the attitude.

The Profound I, or the primordial, non-designated, nonverbal, pre-reflective ego, a support for the intuitive self-identity of the personality and the "seed" of the life possibilities of the I. It is the source of the unconscious dynamics of the attitude to significance in all dimensions, which determines, for example, the mysterious super value and power of the significant over the personality in the outward and inward life.

The Corporeal I experienced and realized under the influence of the deep sensuality of the personality, the vitality it senses, the available self-perception of appearance and bodily dynamics, under the impressions of the personality about the bodies of others, affected by their views, their influences, and their direct responses to its appearance. In addition, the experience of the Corporeal I includes cultural images and ideals of the body that are identical to the personality. With others and culture involved the Corporeal I may continue externally in the dimension of wealth that eludes the person, as Sartre puts it (Sartre, 1953). By means of a socially and culturally enlarged Corporeal I the personality is involved in a real interaction with significance. It performs actions towards the significant, finds itself as acting, embodied in significance, and discovers in own corporeality and activity "traces" of the objectification of the significant.

The Reflexive I, or the Conscious I, that supposes and establishes itself as a source and center of the concentration of acts of consciousness, as a "site" of selfreturn, a subject of dialogue with oneself, and as a point of the integration of the I directed toward the world and "dissolved" in innumerable moments of cognition, experience and action. The I in this hypostasis can constitute and connect all dimensions of a personality's attitude to significance by translating it into the mode of the I - Significance. 
The Dialogic I, or the I that is cognizable, estimated, experienced by the personality in interaction and diverse life dialogues with significant others whom the person has discovered for themselves in culture, society, or intimate communication. It is an aggregation of those elements of the I that are generated in a joint action, in corporeal participation, in the reflection in the inner world of the specific Other, affected by the intrapersonal influence of the Other, and in the mutual contributions made to the outside world. It is the I that imparts dialogicity to own connections with any significances, while involving and revealing the presence of many other people in them. It is the I that is able to enter into various (corporeal, sensual, emotional, mental, figurative-symbolic, verbal, and action) dialogues with significance in each individual dimension of the attitude and to link them to each other by maintaining a dialogical attitude in general.

The Active $I$ as an I capable of productive activities in the world, spiritual creativity, self-activity. It is the I that realizes the life project "to be" and "to be fulfilled in being" through the multiplication and development of values, by performing acts and deeds and improving oneself as a subject of action. The personality possessing this I directly participates in a real relation "between" itself and significance and transforms it into a complex, conscious, directed, meaningful process of productive activity towards the significant. In addition, the Active I is represented in the being of significance as one of its driving forces, and at the same time, it senses in its own inner being the subjectness of significance caused by the interaction with it. The Active I in the realization of personal relations recreates impressions of own activity, success and possibleness by developing the dimension "in-itself" and generating an intention to live "in-the-world" beyond a specific relationship.

The Collective I, or the I experiencing influence and having an impact on many people. It may be partly reflected on and partly it shines through in selfconsciousness as the "unknown self." It is the I that is looked at and shares the feelings and actions of others. It experiences and comprehends the impressions of it being manifested in the environment. It identifies with the cultural images of others and becomes a source of identification for many in the creation of culture. Realizing its "dispersion" and active presence in others, the I strives to "assemble itself" but often comes across impassable places in the mysterious spaces of another's being. In relation to significances the Collective I brings moments of positive experience acquired in partnership, intimacy, and co-creation with others about the significant; it enriches the "in-itself" dimension with responses to own existence, which emanate from others, and it also acquires, in relation to the resource of positive sociality translated by the person "into the world."

The Designated I as one that has a verbal equivalent in the form of the "I" symbol, which acts as a cultural gift, an "instrument" that allows the person to consciously establish own presence in relation to itself, to transform conscious being "for self" into being "in self," to fill the own I with a steady content and meaning, and to achieve self-identity. The I is a word, a name, a symbol used by a person constantly and at the same time, only once at every moment of life, when addressing the unique "self," in the situation I-here-and-now. Being designated, the 
I can comprehend its belonging to the Universal I and own individuality; it can hold its life in all mankind time, as well as in the unique moments of a personal time. In the context of the attitude to significance the I enables the maintained continuity and completeness of the reflexive dialogue with self, which can take place in any dimension of the attitude and, above all, in the "in itself" dimension.

Among an individual's life relations the relation of the I-Other is distinguished where the Other is a specific significant person. The focus on this relation is relevant as it has a special importance for the development and realization of many life relations, where the connections of the I with significances are mediated by the impacting, facilitating and productive presence of another person.

It is essential that in relation to the Other self-relationship of an individual develops. This is due to the possibility of a holistic awareness of own being in an interaction with the Other in the outer world, in the inner world of the Other, in own inner world, and in the space of the I-in-itself. As Sartre points out, the I's being-for-Other, that is an I-object, is not an image of the I inhabiting in someone else's consciousness; this being is absolutely real, the I's being as a condition of selfhood against the Other and the Other's selfhood as opposed to the person (Ibid.).

When analyzing the dialogical unfolding of the relation I-Other, the following regularities revealed in the studies of reflected subjectness of V. A. Petrovsky can be emphasized (Petrovsky, 2010) and in our research of the possibilities of the I in relation to the Other (Starovoytenko, 2013, 2015, 2016).

- This is a conscious or intuitively experienced I activity of the Other in his inner world and own activity of the I, whose influence the Other feels and is aware of, while sharing his outward and inward life;

- Forms and modes of the I's activity continued by the Other and in the Other that keep "traces" of its individuality and absorb the subject efforts of the Other involved in this activity;

- The spontaneous action of spiritual and active contributions of the Other that unconsciously entered into the inward and outward life of the I, or, in the words of V. A. Petrovsky, the "transformed subjectness" of the Other;

- The contributions in-itself recognized by the I when referring to the I reflected in the Other, to the I that reflects the Other, and to the I-integral of these reflections;

- The I having no knowledge of own subjectness in the Other, which is derivative of the hidden self-movement of its influences in the inward world of the Other; the existence of the unknown I in the Other;

- The discovery by the I of own activity represented in the consciousness of the Other, which embodies a massive amount of consciousnesses and selfconsciousnesses and of its activity as acquired through the Other a new unknown scope and a prospect of spreading in a multitude of people.

The I-Other relation in its dialogical dynamics reproduces all the stages of development and realization of the attitude to significance discussed above. At the same time, in relation to the Other (as in other relations), non-dialogic tendencies 
of the attitude can arise and manifest. We shall consider a number of conceptual models that generalize these trends and their personal conditions.

\section{The existential model of regression in the dialogicity of the I-Other relationship}

This model is developed by reconstructing the ideas of Sartre's existential concept (Sartre, 1953), which quite fully embraces the dynamics of the relationship I-Other in the direction of the regress of dialogue. We shall dwell on some general trends of this dynamics.

1. Imparting the Other with a meaning that does not coincide with its "significance" that consists in trying to use the Other as an object of power or a means of self-affirmation. At the same time, the possibility of the I to be significant for the Other is lost or weakened. The significance of recognizing the personality by the Other depends on the significance of recognizing the Other by the personality, as Sartre assumed (Ibid.).

2. Failure to go through necessary cycles of mutual "negation" with the Other in the developing attitude towards it, that means a lost ability of the I to distinguish self from the Other as an object, to experience and accept own objectness for the Other, to recognize the mutual objectness of each other in a reflexive address to self, to reveal the own I and the existence of the I of the Other in mutual denial or the assumption of objectness and the "otherness" of each other, to fulfil the freedom, or subjectness, of each in the realization of each other's opportunities. The reduction of these cycles will mean the loss of the dialogue "facing each other," the lack of reflexivity as a condition and result of the dialogical position of the I. Sartre points out that non-reflexive consciousness does not comprehend the personality directly as its object; the personality itself is represented to consciousness, because it is an object for the other (Ibid.).

3. The corporeality and the corporeal expression of the Other ignored by the I in the direct interaction or the former deprived of reality and factuality for itself. That is, the Other as a "synthetic unity" of the experiments of the I (facial expressions, views, deeds, actions) ceases to organize its experience of dialogicity.

4. The I's being in the "invisibility" for the Other and for itself, or the I's being unaware that it is seen, and the ignorance of own corporeality of the I in connection with the lack of perception of the Other's viewpoint. From the very beginning the Other's opinion is an intermediary that sends the I back to it (Ibid.). When the I slips away from the Other's view, it does not exist for itself. In this case, when the view of the Other completely masters the world of the "external I," it is impossible to get out of its position of an object-for-Other.

5. The existence of the I for the Other and the Other for the I not as mutually recognized individualities, but as "everyone," sharing with many others the use of the instruments of the world, which belong to "all" and unite all in an impersonal unity. The arising non-acceptance of each other in the authenticity of being transforms the real interaction into a "shared loneliness." 
6. Lack of the I's addressing to the Other as an "object" or a lost opportunity for the I to understand its givenness in the Other, and also to make its unknown I, given to the Other, an object of self-knowledge.

7. Failure to understand that the Other is always multiple-valued ass it embodies a multitude of consciousnesses and self-consciousnesses, and that the givenness of the I as an object for the Other and in the Other gives this object a volume and abundance that is inaccessible to self-consciousness if it tries to get rid of the Other. The I is the way the Other knows and sees it, who has wealth that can elude from the I, but can be revealed in dialogue.

8. The freedom of the Other not recognized, which does not allow the I to comprehend its appearance and its actions as seen by the Other, to know itself in its unknown being in this Other, to allow the Other to equal the possibilities of the I to own possibilities for joint action, as well as to use the possibilities of the Other to master and apply objects that without it escape from the I, to recognize the value of the existence of the Other for self. The negation of the freedom of the Other arising in the relation leads the I to the restriction of own freedom.

9. The I experiencing the danger of being an object for the Other. of own helplessness over the unforeseen evaluations by the Other, the feeling of self as an instrument of alien possibilities and a means for the unknown goals of the Other; the feeling that the Other perceives the I in a wrong way, the I's negative evaluation of self as viewed by the Other; the feeling of the Other as a power that one does not possess, in particular as a discoverer of the secret being of the I; the fear that the Other can lose the I as an object and realize its opportunities aimed at-others.

10. The I does not accept the risks of contacting the freedom of the Other, which consists in rejecting "self" as seen and assessed by the Other. Usually when the Other describes the character of the I, it does not recognize itself and gets alienated, but at the same time it knows that "this is the I," without ceasing to be a "foreigner." When the I denies itself in the Other, or the alienated I disappears, it entails the disappearance of the Other through the collapse of the I itself (Ibid.).

11. The I does not accept the responsibility for the existence of the Other, when the I ceases to recognize the subjectness of the Other in relation to it and to itself, when it does not fulfil the possibility to give an existence to the Other in its objectness for itself, when it does not reveal a new existence of the Other in its freedom in relation to it, when it cannot establish an internal identity with the Other by continuing its assets in its own being.

12. The I losing "itself" if its objectness is not recognized for the Other. The I begins to reject itself as being viewed, known, and evaluated by the Other; in front of the Other it feels "stratified" and unrecognizable by itself. The I makes an attempt to slip away from the Other's sight, to hide its body and actions, to close down for evaluative statements in its address, not to look for itself in the Other. Therefore the I appears faced by emptiness, where the I could exist in-itself-for-itself.

13. "Blindness" as a refusal to the Other in subjectivity. This is the Other's view ignored, which turns into an object for the I; this is also the unawareness of itself in the being of the Other; this is the "absorbing" of the Other into itself without 
realizing its presence and activity. The Other becomes an object among an enormous amount of objects, which the I can affect by its actions. Sartre emphasizes that the state of blindness can last for long at the whim of the personality's fundamental self-deception; it can last intermittently for many years, all life; there are people who die without suspecting anything, except for brief and terrifying insights that it was the Other (Ibid.).

14. Temptation as self-affirmation for the I as the most significant object for the Other on the basis of its subjectivity conquered and exceeded. On the one hand, the actions of the I point to an infinite series of real and possible actions that create for the Other its objective being and reveal its unknown being. On the other hand, the actions of the I point to the excessive density of the possible world that is given to the Other, and to the I as the only mediator in its connections and achievements in the world.

The above tendencies of non-dialogicity can arise in connection with the personality properties, which are prerequisites for avoiding or regressing the dialogue in relation to the Other. Such prerequisite properties can involve, for example, the insufficient strength of the I, non-reflexiveness, the love of power, the propensity for dependence, the inability of the I to combine the subjectness and the objectness of the I and others in relationships.

\section{The model of personal prerequisites of non-dialogicity in relation to the I-Other}

Personality properties that negatively affect the formation and dynamics of dialogue in relation to the Other are systematically presented in the psychoanalytic concept of Nancy McWilliams (McWilliams, 1994). They act here as "characters," or "types of adaptation."

Sociopathy: the propensity of an individual to manipulate and use others; search for one's "omnipotence" to be confirmed in the interaction with others; the avoidance of identification with others in favour of appealing to oneself in one's own desire for power and superiority. Inability to form intimate relationships; neglect of care and tenderness towards others. When another person is perceived as a useful object or object of power, the individual may seem charming and enticing.

Narcissism: excessive self-absorption at the expense of the others' significance; self-esteem achieved by attesting to own merits from others. Self-esteem is maintained through the use of other people who possess greater abilities and talents ("narcissistic expansion" of the personality); a combination of idealization and depreciation in the inner attitude to others. Strong criticism of oneself associated with the inconsistency of an "ideal" another.

Paranoid personality: the dependence of a person on a significant, authoritative another; a sense of danger due to the uncertainty of the behaviour and inner world of significant others; the conflict of the image of the I "degraded by others" in the individual's power and superiority; considering "others" as being a cause of the individual's failures; the experience of defeat in attempts to establish control over others to minimize threats on their part. 
Self-destruction: the experience of "undeserved" suffering caused to the individual by the actions of significant others; the perception of oneself as a victim of persecution by others, along with a strong experience of own guilt; unconscious search in other people for the source of own "badness;" causes of low self-esteem internally redirected to others.

Obsessive-compulsive personality: formal, distant interaction of the individual with others, despite the unconscious craving for attachment; external forms of communication predominate, which are full of intellectualization and moralizing, but lack in the strength of a fulfilled life and giving value to others.

Hysterical personality: the search for protection and security in other people and the recognition of the individual's accomplishments by them; achieving self-esteem through controlling and manipulating influences on others.

These properties, with critical levels of the expression in an individual, are the reasons for the impossibility of not only a dialogical attitude to the Other, but also of the attitude as such. When the properties are moderately expressed, the attitude and its dialogicity either remain "unfulfilled" or gain a prospect of regression.

In our studies not only the general tendencies of regression of the dialogic nature of the I-Other relationship are revealed, but also a number of specific nondialogical tendencies are shown that arise in the dynamics of various dimensions of the attitude as an opposition to dialogue. They can be determined by the positions or states of the I, depend on the Other and on the reaction of the I to the Other's attitude. We believe that the reflection and constructive actions of an individual with such oppositions can lead to the reconstruction and development of dialogue.

The reflection of non-dialogical tendencies that are specific for different dimensions of the I-Other relationship can be actualized in empirical research, counseling, or self-knowledge using techniques developed on the basis of the following model.

\section{The model of oppositions to dialogicity in the dimensions of the I-Other relation}

Likewise any attitude to significance, the I-Other relation acts as a unity of four dimensions: between-I-and-Other, I-in-Other, Other-in-I, I-in-self-with-Other (Starovoytenko \& Derbeneva, 2017). The original "dimensional" concept of the attitude also determines a new understanding of the dialogic I's genesis (Hermans, 1996, 2001, 2002, 2015) of an individual that complements the existing concepts.

Each dimension of the I-Other relation contains a potential for dialogue, which can be sufficiently effective even when other dimensions are not used. However, a true dialogue-relation is possible only in the completeness of their scope in a person. The oppositions to dialogicity can also be of relevance to both separate dimensions of the attitude towards the Other and their system as a whole.

We shall single out non-dialogical tendencies, which are relevant to each dimension of the attitude that can be discovered by individuals in reflection for their developing correction. Reflection can be modeled by using questions addressed to the I, to clarify how much oppositions to dialogue are inherent in its relation to the Other. 


\section{Between-I-and-Other}

The I experiences and generates shortages of dialogicity and reflexivity in external interactions with the Other. The I cannot stand in the position of observation and reflection of itself in direct interaction with the Other, the I does not know how it may change in the Other's presence. In the dynamics of interaction, the I weakens the realization of its corporeal and mental abilities, or, on the contrary, shows activity at the limit of these opportunities with the threat of exhaustion. In the interaction the I unilaterally fulfills certain forms of mental activity to the detriment of other activity forms that are in demand with the interaction with the Other. The I postpones joint activity, reduces verbal communication; it does not show understanding, restrains experiences, and lends itself to unconscious affections. The I ignores the potential of the Other's direct presence in its life: the I alienates the Other's views, gestures, and utterances addressed to it.

The I decreases the assessment of outward-itself when viewed by the Other. It focuses on the Other to use and manipulate it. The I blocks the activity of the Other or "squeezes" out opportunities for itself from the Other's activities. The I underestimates the involvement and contribution of the Other in joint actions and overestimates own role in the interaction. The I ignores the value aspects of the interaction or resorts to the implementation of anti-values. The I leaves the interaction without achieving the jointly intended result and positive effects for itself and the Other. In the course of the I's activities it "loses sight" of the Other and attributes the result achieved together only to itself; it does not realize its negative influences on the Other's actions and cannot capture positive effects of the Other's activity. The I makes no account of responses to the interaction with the Other produced by the environment. The I does not take into account changes of the Other during the interaction with it.

The I feels a constant dissatisfaction with itself and with the Other in real interaction. The I faces the opposition, passivity, destructive value-semantic position, and the desire for power on the part of the Other, but gives no response. The I does not consider own changes as impacting the Other in the process of interaction. The I interacts with an imaginary but not the real Other. The I informs other people about the negative properties manifested by the Other hoping to "exclude competitors" in the struggle for closeness with or power over the Other. There are various effects of the interaction between-I-and-Other: joint failures, negative influence on the environment, destructive impact on the environment, regress of the subjects of the interaction. The apprehended "We" in the context of the interaction is perceived by the I as weaker than the participants in isolation.

\section{I-in-Other}

The I experiences difficulties in reflection when it turns to the inner world of the Other. The I is confronted with its non-representation in the Other, with the "emptiness instead of self." The I negatively experiences and assesses its non-presence in the inner world of the Other. The I grasps its presence in the Other as indistinct, 
fragmentary, and situational. The I finds severe distortions of itself in the Other or understands its negative reality in it. The I reveals its low subjectness and the weak influences on the Other. The I realizes its insufficient significance for the Other. The I knows about the Other's low activity of thought, imagination, and imagination directed at it. The I experiences and reflects the distancing of the Other in its internal relation. The I is aware that it is impossible "not to be in the Other." The I seeks to master the inner world of the Other and fill it in with self. The I identifies the "inner Other" with itself and ascribes to it own vision of self. The I feels confident in its domination in the inner world of the Other and in accordance with this Other. The I projects a negative self-attitude into its own image in the Other. The I is completely identified with the I-in-the-Other. The I diminishes or idealizes itself based on the assumptions about the evaluations by the Other. The I cannot tolerate the rejection, lack of attention or undervaluation of itself in the inner world of the Other. The I cannot reflexively take its place in the Other, or the I is aware of its failure as seen from that place.

The I experiences the alienation of its image in the Other, denies the negative features of this image and replaces it with a desirable fantasy image. The I is aware of and is experiencing its values and qualities being inwardly ignored of the Other. The I feels the danger of the Other as possessing an unknown knowledge of it. The I reveals the experience of "Us" has a low inner significance for the Other. The I feels real suffering at the thought that the I does not find fulfillment and continuation in the Other. The I loses itself in the Other by recognizing the superiority and power of the latter. The I can see itself only in the image created by the Other and owned by the Other. The I ignores the opportunity to learn about itself-in-the-Other from third parties. The I alienates knowledge of its representation in the Other from real interaction with it.

\section{Other-in-I}

The I has a weak reflexive reality of the Other in-itself. The I has an indistinct, fragmentary, static, and non-reflective image of the Other. When forming its own "inner Other" the I demonstrates a one-sided domination of thought, or a fantasy, or an experience. The I does not notice changes in the inner Other caused by the dynamics of the relationship with it. The I cannot enter into an inner dialogue with the Other as an imaginary, ideal or secret interlocutor. It does not realize how it changes with the internal actualization of the image of the Other. The I attributes to the Other an inexplicable power that internally dominates, suppresses and causes fear. The I experiences and realizes an involuntary absorption by the image of the Other and internally surrenders to it. The I inwardly identifies itself with the Other, it assigns to itself the Other's significant properties, and gradually empties its image. The I feels its superiority as an owner of the inner "unknown Other." The I uses the Other as own "function" or "expansion," thus internally depriving the Other of an autonomous existence. The I is hardly aware of the activity of its "inner Other" and experiences the activity effects as a "stranger's" invasion. The I does not comprehend the value influences of its "inner Other". 
The I represents the Other as its inner mirror, which reflects mainly its negative features. The I experiences attachment to the "inner Other" as a reflection of its ideal qualities. The I has negative feelings and thoughts dominating about the imagined Other. The I does not see the oneness with the Other in the phenomenon of the inner "We." The I subjectively excludes the Other's potential from the conditions of its development. The I establishes internal power over the Other despite the balance of power in the external interaction. The I devalues the "inner Other" as it defends itself against its extremely high significance. The I internally accepts the Other as a standard for itself that is not subject to doubt and reassessment. In its "inner Other" the I sees a critic, an inhibitor and a censor of own creative ideas. The I internally "exposes" the imagined Other and involuntarily moves towards the loss of the relation. The I imagines the Other as an elusive, mysterious significance that is not accessible to relations. The I uses the possibilities of its "outsidedness" for the Other, inwardly attributes to it dubious features and mocks it. The I does not accept the knowledge of the Other, which is owned by others. The I does not accept or uncritically accepts the image of the Other created by others. The I cannot achieve the unity of the imagined and real Other, which makes the attitude towards it dubious.

\section{I-in-itself-with-Other}

The I cannot reflexively master various dimensions of the I-Other relationship. The I is fragmentary and situationally presented to itself in the context of the attitude to the Other. The I does not create the image of an external self through the Other. The I does not address itself as its own interlocutor when defining the relation to the Other. The I cannot be itself in the presence and interaction with the Other. The I cannot enter into self-relationship in the external and internal relation to the Other. The I experiences a weakening self-acceptance, a decrease in self-esteem, an increase in mistrust and doubts in itself in the dynamics of attitudes toward the Other. The I cannot reflect and integrate its self-experiences, corporeal images of self and the knowledge about self that appear in relation to the Other. The I does not retaliate against its dependence on the Other, which is hurtful and traumatizing. The I, when identifying with the Other, either appropriates the Other's strengths, or ascribes, or "gives away" to it its own merits. The I does not attain the "forthcoming" meaning of the Other's presence in its life.

The I does not feel the build-up of its life possibilities in relation to the Other. The I experiences a shortage of own activity in joint activities and experiences restraint in self-expression "under the eye" of the Other. The I does not feel trust in itself, the sustainability of its intentions and progressive productivity in relation to the Other. The I avoids insights into the "unknown in self," which emerges in the interaction with the Other. The I does not identify with the Other and loses or does not gain the experience of "We." The I is not capable of strengthening itself, self-affirmation in the presence and in the interaction with the Other. The I cannot grasp the "possible self," create an image of the "ideal self," make a "draft of the I" in the context of its relationship with the Other. The I experiences a "withdrawal," 
the loss of self when the I reacts to the Other. The I ignores the images of "itself" in relation to the Other, which exist in the minds of others. The I attributes achievements and failures in the interaction with the Other only to itself. The I does not feel own changes in the dynamics of relations with the Other. The I does not understand the Other's place in its life and experiences a strong "loneliness together."

These non-dialogical tendencies can become a subject of reflexive problematization of self for the I, which leads to positive transformations of an individual's positions in relation to the Other. On the basis of this "selfconfrontation" (Hermans, 2006-2007), non-dialogicity in relation to the Other becomes a condition for the resumption of dialogue with it.

Regression and opposition to dialogue do not exhaust the influence of nondialogicity on the I-Other relation in the context of the individual life. Sometimes non-dialogic nature can become a condition for the existence of a relationship. For example, in the experience of love situations may arise when, in order to save it, some of the most important moments of dialogicity must be eliminated. Intentions to dialogue paradoxically ruin love or plunge lovers into trouble.

The need to exclude dialogicity in love and the consequences of its "nonexclusion" have a cultural and psychological genesis and are represented in a variety of archetypal and symbolic phenomena. We shall show a few situations, when the characters in a myth should exclude dialogicity, but do not do it.

"Eliminate the view of the Other." The phenomenon of Orpheus who violated the prohibition to look at his Beloved, which resulted in their death.

"Do not show yourself to the Other." The phenomenon of Cupid who involuntarily showed himself to his Beloved and subjected her and their love to hard trials.

"Do not reveal the secret of the Other." The phenomenon of Jocasta who did not escape the discovery that her beloved husband, Oedipus, is her son.

"Do not reveal your secret to the Other." The phenomenon of Phaedra who did not preserve the truth of her love for Hippolytus and thus destroyed him and herself.

In an individual's attitude to significance the boundary of dialogicity and nondialogicity may be subtle and permeable. In their change, interaction and domination, conditions for development, conflict or destruction of relations are created. The personality's reflection that captures the dynamics of relations can find creative solutions to enhance their dialogicity based on overcoming or using the hidden resource of non-dialogical tendencies.

\section{References}

Bakhtin, M. M. (1986). Estetika slovesnogo tvorchestva [Aesthetics of verbal creativity]. Moscow: Iskusstvo. (in Russian)

Borisov, E. V. (1997). Dialog kak sud'ba. So-Bytiye s Drugim v ekzistentsial'noy analitike M. Khaydeggera [Dialogue as fate. Co-Being with the Other in the existential analytic of M. Heidegger]. Istoriya Filosofii [History of Philosophy], 1, 81-98. (in Russian) 
Buber, M. (1993). Ya ity [I and Thou]. Moscow: Vysshaya shkola. (in Russian) (Transl. of: Buber, M. (1971). I and Thou. New York: Scribner's.)

Dimaggio, G., Salvatore, G., \& Hermans, H. J. M. (2003). Dialogical relationships in impoverished narratives: from theory to clinical practice Psychology and Psychotherapy: Theory, Research and Practice, 76, 385-409.

Florenskaya, T. A. (2001). Dialog v prakticheskoy psikhologii. Nauka o dushe [Dialogue in practical psychology. The science of the soul]. Moscow: Vlados. (in Russian)

Hermans, H. J. M. (1996). Opposites in a dialogical Self: constructs as characters The Journal of Constructivist Psychology, 9, 1-26.

Hermans, H. J. M. (2001). The dialogical self: toward a theory of personal and cultural positioning. Culture and Psychology, 7(3), 243-281.

Hermans, H. J. M. (2002). The person as a motivated storyteller: Valuation theory and the self-confrontation method. In R. A. Neimeyer \& G. J. Neimeyer (Eds.), Advances in personal construct psychology: New directions and pespectives (pp. 3-28). Wesport, CT: Praeger Publishers.

Hermans, H. J. M. (2006-2007). Lichnost' kak motivirovannyy rasskazchik: teoriya valyuatsii i metod samokonfrontatsii [Personality as a motivated narrator: the theory of valuation and the method of self-confrontation]. Postneklassicheskaya Psikhologiya: Sotsial'nyy Konstruktsionizm i Narritionyi Podkhod, 1(3), 7-53. (in Russian)

Hermans, H. J. M. (2015). Dialogical self in a complex world: The need for bridging theories. Europe's Journal of Psychology, 11(1), 1-4.

Kopiev, A. F. (1999). Vzaimootnosheniye "Ya" - "Drugoy" i yego znacheniye dlya prakticheskoy psikhologii. K integrativnoy kontseptsii psikhologicheskoy pomoshchi [The relation I-Other and its meaning for practical psychology. To the integrative concept of psychological care]. Moskozskiy Psikhoterapeoticheskiy Zhurnal, 2, 48-60. (in Russian)

Levinas, E. (2006). Humanism of the Other. Urbana, IL: University of Illinois Press.

Maranhao, T. (1990). The interpretation of dialogue. Chicago, IL: University of Chicago Press.

McWilliams, N. (1994). Psychoanalytic diagnosis: Understanding personality structure in the clinical process. New York: The Guilford Press.

Petrovsky, V. A. (2010). Chelovek nad situatsiey [The person over the situation]. Moscow: Smysl. (in Russian)

Petrovsky, V. A. (2013). "Ya" v personologicheskoy perspektive [The I in the personological perspective]. Moscow: The HSE Publishing House. (in Russian)

Puchalska-Wasyl, M., \& Oles, P. (2013). Doubtfulness - a dialogical perspective. Psychology of Language and Communication, 17(2), 101-113.

Rivetti Barbo, F. (1983). Dialogue: a how do we know what others mean and why? In K. B. Cohen \& M. W. Wartofsky (Eds.), Language, logic and method (pp. 409-444). Dordrecht, NL: Reidel.

Sartre, J.-P. (1953). Existential psychoanalysis. Chicago, IL: Henry Regnery Company.

Starovoytenko, E. B. (2013). Capacities of the I in relationship with the Other: Hermeneutics and reflection. Psychology. Journal of Higher School of Economics, 10(4), 121-142. (in Russian)

Starovoytenko, E. B. (2015). Personologiya: zhizn' lichnosti v kul'ture [Personology: the individual's life in culture]. Moscow: Akademicheskiy proyekt. (in Russian)

Starovoytenko, E. B. (2016). Genez Ya v otnoshenii k Drugomu [Genesis of the I in relation to the Other]. In M. I. Volovikova, A. L. Zhuravlev, \& N. E. Kharlamenkova (Eds.), Psikhologicheskiye issledovaniya lichnosti: istoriya, sovremennoye sostoyaniye, perspektivy [Psychological studies of personality: history, current state, prospects] (pp. 117-135). Moscow: Institute of Psychology of the RAS. (in Russian) 
Starovoytenko, E. B. (2017). Productivity of the dialogical relationships Self - Other. Psychology. Journal of Higher School of Economics, 14(3), 408-432. (in Russian)

Starovoytenko, E. B., \& Derbeneva, A. A. (2017). Resources of a "Conversation partner" in dialogical I - Other relationship. Psychology. Journal of the Higher School of Economics, 14(2), 356-376.

Zittoun, T. (2014). Three dimensions of dialogical movement. New Ideas in Psychology, 32, 99-106.

Elena B. Starovoytenko - professor, head of the Department of Personality Psychology, School of Psychology, Faculty of Social Sciences, National Research University Higher School of Economics, D.Sc.

Research area: methodology of psychology, theoretical psychology of personality, personology, psychology of life relationships of personality, cultural personality psychology, psychology of cognition, psychology of reflection.

E-mail: helestaOS@yandex.ru

\section{Недиалогичное отношение к Другому: регресс или оппозиция диалогичности}

\section{Е.Б. Старовойтенко}

${ }^{a}$ Национальный исследовательский университет «Высшая школа экономики», 101000, Россия, Москва, ул. Мясницкая, д. 20

\section{Резюме}

Исследование, представленное в данной статье, посвящено разработке теоретических моделей диалогичности и недиалогичности отношения личности к Другому. Основываясь на философских и психологических исследованиях диалога (М.М. Бахтин, М. Бубер, Ж.-П. Сартр, E. Levinas, H.J.M. Hermans, T. Maranhao, M. Puchalska-Wasyl, F. Rivetti Barbo, T. Zittoun), автор акцентирует вовлеченность личности в разные формы активности, которые, благодаря ее усилиям, приобретают диалогичный характер. Среди этих форм выделяются «отношения личности к значимостям», в том числе отношение к другой значимой личности. Развивается авторское понимание диалогичности отношения к Другому как полноты его реализации в измерениях между-Я-и-Другим, Я-в-Другом, Другой-в-Я, Я-в-себе-с-Другим. Недиалогичность, крайне редко выступающая предметом психологических исследований, определяется, во-первых, как одна из возможностей становления отношения к Другому, во-вторых, как регресс диалогичного отношения, втретьих, как бинарная оппозиция, присутствующая в сознательном плане или «в тени» диалогичной динамики отношения, в-четвертых, как тенденция, конфликтующая с диалогичностью в пользу развития диалога. В соответствии с многосторонним взглядом на генез диалогичности-недиалогичности отношения личности к Другому разработан ряд теоретических моделей: модель диалогичного отношения к значимости; модели «Я» в контексте диалогичного отношения; экзистенциальная модель регресса диалогичности 
отношения Я - Другой; модель личностных предпосылок недиалогичности в отношении Я - Другой; модель оппозиций диалогичности в измерениях отношения Я - Другой.

Ключевые слова: личность, Я, Другой, отношение, рефлексия, диалог, диалогичность, недиалогичность, регресс, оппозиция, герменевтика, модель, теория.

Старовойтенко Елена Борисовна - заведующая кафедрой психологии личности, департамент психологии, факультет социальных наук, Национальный исследовательский университет «Высшая школа экономики», доктор психологических наук, профессор.

Сфера научных интересов: методология психологии, теоретическая психология личности, персонология, психология жизненных отношений личности, культурная психология личности, психология познания, психология рефлексии.

Контакты: heletstaOS@yandex.ru 


\title{
Короткие сообщения
}

\section{ПРАЙМИНГ-ЭФФЕКТЫ В ЗАДАЧЕ ЛЕКСИЧЕСКОГО РЕШЕНИЯ НА СТИМУЛАХ-СЛОВАХ С ОДИНАКОВЫМ БУКВЕННЫМ СОСТАВОМ}

\author{
Н.М. ЛАПТЕВА ${ }^{\mathrm{a}}$, Е.А. ВАЛУЕВА ${ }^{\mathrm{a}, \mathrm{b}}$, С.С. БЕЛОВА ${ }^{\mathrm{a}}$
}

${ }^{a}$ ФГБУН «Институт психологии РАН», 129366, Москва, ул. Ярославская, д. 13, к. 1

${ }^{b}$ Московский государственный психолого-педагогический университет, 127051, Россия, Москва, ул. Сретенка, д. 29

\section{Резюме}

Статья представляет экспериментальное исследование, в котором оценивались праймингэффекты в задаче лексического решения на стимулах-словах с одинаковым буквенным составом. Были подобраны 36 пар слов, в которых одно из слов можно преобразовать в другое путем перестановки букв. На первом этапе испытуемому предлагалась задача «Пары слов», с помощью которой проводилась предактивация одного из двух слов, возможных для данного буквенного состава. На втором этапе испытуемые решали задания теста пространственного интеллекта. На третьем этапе испытуемые выполняли задачу лексического решения, в которой в качестве стимулов использовались предактивированные, альтернативные и контрольные слова. Гипотеза исследования заключалась в том, что экспериментальное воздействие будет соответствовать результатам, получаемым в экспериментах с неосознаваемым праймингом, а именно: 1) слова, идентичные предъявленным ранее праймам, будут демонстрировать позитивный прайминг-эффект, а 2) слова с тем же буквенным составом, что и у праймов, но альтернативной семантикой - негативный. Результаты показали, что время реакции на предактивированные слова значимо выше, чем на альтернативные и контрольные. Вместе с тем альтернативные слова распознавались медленнее, чем контрольные, хотя они не предъявлялись на первом этапе и испытуемые не знали, что из букв предъявленного слова можно составить другое. С точки зрения моделей зрительного распознавания слов такие результаты объясняются тем, что семантические процессы оказываются включенными в опознание слов на ранних этапах, поэтому происходит оттормаживание стимулов, имеющих альтернативную семантику. Однако, учитывая, что мы изменили классическую процедуру неосознаваемого прайминга с маскировкой на осознаваемый отсроченный прайминг, мы предполагаем, что полученные результаты отражают 
общие закономерности функционирования мышления. Так, установленные эффекты согласуются с данными, полученными при изучении влияния инкубации на решение анаграмм с двумя решениями, описанными Е.А. Валуевой. Одной из возможных теоретических интерпретаций полученных данных является теория В.М. Аллахвердова о неосознанном негативном выборе.

Ключевые слова: прайминг, перестановка букв, распознавание слов, задача лексического решения, творчество, негативный выбор.

\section{Введение}

Модели зрительного распознавания слов нацелены на понимание механизмов восприятия слов при чтении. Они разрабатываются с целью максимально точно описать, предсказать и воспроизвести феномены, фиксируемые в экспериментах по распознаванию и чтению слов (Norris, 2013). Многочисленные эксперименты направлены на все большее и большее уточнение нюансов восприятия слов. Вместе с тем когнитивная система человека представляет собой единый сложный механизм, поэтому в конечном счете от того, как человек распознает и понимает слова, должно зависеть то, как он думает и решает задачи.

Мы ставим задачу показать, каким образом почти «обычный» (с точки зрения моделей распознавания слов) экспериментальный факт может связать две совершенно разные области психологических исследований - область изучения зрительного восприятия слов и психологию творчества.

Наиболее частыми процедурами в экспериментах по зрительному распознаванию слов являются задача лексического решения (lexical decision task) и прайминг. В общем виде прайминг представляет собой воздействие, влекущее за собой более точное или быстрое решение задачи. Так, например, при лексическом прайминге повторением (word repetition priming) происходит уменьшение времени реакции на стимулы-слова, которые ранее предъявлялись испытуемым (например: Ratcliff et al., 1985; Scarbrough et al., 1977).

Одним из распространенных приемов является использование в качестве праймов слов с перестановкой букв (transposed letters primes, например: stduent/student, jugde/judge). Показано, что в задаче лексического решения праймы с перестановкой букв (ППБ) эффективнее контрольных праймов, причем этот эффект более выражен при перестановке букв в середине слова, чем в конце (Perea, Lupker, 2003). Общепринятой является интерпретация позитивного прайминг-эффекта стимулов с перестановкой букв в связи с гибкостью кодирования позиции букв в слове (Mousikou et al., 2015).

Особым случаем ППБ являются слова, перестановка букв в которых приводит к образованию нового слова (casual/causal, minute/minuet). Например, праймом выступает слово «мотель», а целевым словом в задаче лексического выбора - слово «отмель» (другие примеры: старина/санитар, петарда/адаптер). При одинаковом буквенном составе прайм и целевой стимул обладают разной семантикой. Экспериментальные данные в отношении ППБ-слов не 
очень многочисленны. Однако показано, что ППБ-слова (в отличие от ППБне-слов) по меньшей мере не демонстрируют позитивного прайминг-эффекта (Алексеева, Слюсарь, 2017; Dunabeitia et al., 2009), но в некоторых условиях могут замедлять переработку слов с идентичным буквенным составом (Andrews, 1996). Более того, слова, из букв которых можно составить альтернативное слово, предъявленные сами по себе без прайма, требуют большего времени для переработки по сравнению с контрольными словами (Andrews, 1996; Taft, Van Graan, 1998). С точки зрения моделей распознавания слов такие результаты свидетельствуют о том, что семантические процессы оказываются включены в опознание слов на очень ранних этапах переработки букв (Carreiras et al., 2014).

Имеют ли подобные эффекты прайминга лишь локальное значение, в конечном итоге позволяющее нам прочитать слово на 20 мс быстрее или медленнее? Или, возможно, феномены, регистрируемые в парадигме изучения зрительной переработки слов, могут помочь нам в понимании глобальных процессов мышления? Для ответов на эти вопросы мы провели исследование, в котором изучали эффекты прайминга на словах с одинаковым буквенным составом, изменив традиционную процедуру в нескольких отношениях.

В исследованиях зрительного распознавания слов, как правило, используется неосознаваемый прайминг с маскировкой - прайм предъявляется на очень короткое время (50-60 мс) непосредственно перед предъявлением целевого стимула. В таких условиях испытуемые, как правило, не имеют возможности осознать производимую манипуляцию.

В нашем исследовании мы предъявляли праймы на время, достаточное для их сознательной переработки, все праймы предъявлялись одним блоком, при этом праймы и целевые слова были разделены выполнением дополнительного задания. Гипотеза исследования заключалась в том, что результаты нашего экспериментального воздействия будут отражать результаты, получаемые в экспериментах с неосознаваемым праймингом, а именно: 1) слова, идентичные предъявленным ранее праймам, будут демонстрировать позитивный прайминг-эффект, но 2) слова с тем же буквенным составом, что и у праймов, но альтернативной семантикой - негативный.

\section{Метод}

\section{Испьтутемые}

В исследовании приняли участие 84 человека (12 мужчин, 72 женщины), от 16 до 56 лет, средний возраст - 26.25, стандартное отклонение -10.14 . Участники набирались на добровольной основе в сети Интернет.

\section{Стимульный материал}

Основным стимульным материалом выступили 5-7-буквенные слова (существительные русского языка в начальной форме единственного числа) 
с одинаковым буквенным составом, составляющие пары (например, подкова - паводок, жандарм - мандраж), всего 72 слова (36 буквенных составов).

В пару к каждому слову было составлено искаженное слово путем случайной замены одной из букв (гласная всегда заменялась на гласную, согласная на согласную таким образом, чтобы структура слова сохранялась, например: паводок - паводос, санитар - санатар).

Также было сконструировано 72 псевдослова. Для этого были подобраны слова, не имеющие прямых ассоциаций со словами из основного набора. При этом количество пяти-, шести- и семибуквенных стимулов было такое же, как и в основном наборе. Псевдослова составлялись путем случайной замены одной из букв (гласная всегда заменялась на гласную, согласная - на согласную, например: волоток, силонка).

Таким образом, в стимульный материал входили 72 основных слова, 72 искаженных основных слова и 72 псевдослова ${ }^{1}$.

72 основных слова были разбиты на две группы по 36 слов (18 пар слов с одинаковым буквенным составом, группа А и группа В). Каждая из этих групп, в свою очередь, была разбита на две подгруппы: в одну из них (A1, B1) вошли «первые» слова, которые можно составить из буквенного состава, а во вторую (A2, B2) - «вторые»². Таким образом, в каждую из четырех групп (A1, A2, B1, В2) вошли 18 слов, при этом из слов группы А1 можно было составить слова группы A2, а из слов группы В1 можно было составить слова группы В2. Списки слов представлены в Приложении.

\section{Прочедура}

Сбор данных осуществлялся посредством онлайн-тестирования, реализованного на платформе PsyToolkit (www.psytoolkit.org) (Stoet, 2010, 2017). Исследования показывают, что онлайн-тестирование является достаточно надежным способом получения результатов о времени реакции (BP). При онлайн-тестировании, как правило, наблюдается систематическое увеличение показателей ВР, однако относительные разницы ВР на разные типы стимулов оказываются сопоставимы с эффектами, получаемыми в лабораторных условиях. Было продемонстрировано, что в онлайн-исследованиях в большинстве случаев воспроизводятся результаты классических экспериментов в парадигме измерения времени реакции (Brand, Bradley, 2012; Chetverikov, Upravitelev, 2016; Schubert et al., 2013; Semmelmann, Weigelt, 2017), в том числе в отношении задачи лексического решения (Hilbig, 2016).

Эксперимент состоял из трех этапов.

На первом этапе испытуемые выполняли задачу, названную нами «Пары стимулов». На экране предъявлялись два стимула: слово из основного набора

\footnotetext{
${ }^{1}$ Фактически искаженные основные слова также являются псевдословами, но мы будем их называть «искаженные основные» для ясности терминологии.

${ }^{2}$ Разделение на «первые» и «вторые» слова условно и произвольно, поэтому эти обозначения взяты в кавычки.
} 
и соответствующее измененное слово. Задача испытуемого состояла в том, чтобы определить, с какой стороны находится слово, написанное без ошибки, - справа или слева. Расположение основного и искаженного слова (справа или слева) в каждой пробе, а также порядок предъявления пар были случайными. Слова были напечатаны белым шрифтом Times New Roman 24 кегля на черном фоне на расстоянии 200 пикселей друг от друга. Перед появлением каждой пары испытуемым на 500 мс предъявлялась фиксационная точка (знак «+») в центре экрана. Испытуемый должен был нажать 1, если правильное слово располагалось слева, и 0 - если справа. Слова оставались на экране до ответа испытуемого.

Все испытуемые были случайным образом разбиты на четыре группы так, что каждой группе предъявлялась лишь одна группа слов - A1, A2, В1 или В2. Таким образом, каждый испытуемый участвовал всего в 18 пробах.

Перед выполнением основного задания испытуемый выполнял шесть тренировочных проб (со словами, не имеющими отношения к экспериментальным словам), в которых ему давалась обратная связь о правильности ответов. В основной серии обратная связь о правильности ответов не предоставлялась.

На втором этапе испытуемые решали 15 заданий пространственного теста (Yoon, 2011), что обеспечивало их вре́менное переключение на новую задачу.

На третьем этапе испытуемые выполняли задачу лексического решения.

В качестве стимульного материала выступали 72 основных слова, а также 72 псевдослова (всего 144 пробы). На экране предъявлялся стимул, и задача испытуемого состояла в том, чтобы определить, предъявляется слово или псевдослово. Стимулы были напечатаны белым шрифтом Times New Roman 24 кегля на черном фоне в центре экрана. Перед появлением каждого стимула испытуемым на 500 мс предъявлялась фиксационная точка (знак «+»). Испытуемый должен был нажать 1, если предъявлялось слово, и 0 - если псевдослово. Стимулы оставались на экране до ответа испытуемого. Порядок предъявления стимулов был случайным. Перед выполнением основного задания испытуемый выполнял шесть тренировочных проб, в которых ему давалась обратная связь о правильности ответов. В основной серии обратная связь о правильности ответов не предоставлялась.

Задание и стимульный материал на третьем этапе были одинаковыми для всех испытуемых.

\section{Результаты}

Для проверки гипотез нашего исследования был произведен анализ данных задачи на лексическое решение.

В задании на лексическое решение все испытуемые получали одинаковый набор стимулов. Однако на первом этапе (в задании «Пары стимулов») каждая из четырех групп испытуемых получала лишь один из четырех наборов слов, поэтому слова на третьем этапе оказались принадлежащими одной из трех категорий: 
1) предактивированные (слова из группы, предъявлявшейся испытуемому на первом этапе эксперимента);

2) альтернативные («вторые» слова, имеющие тот же буквенный состав, что и предактивированные слова, но не предъявлявшиеся испытуемому на первом этапе);

3) контрольные слова (слова той группы, буквенный состав которой вообще не предъявлялся испытуемым на первом этапе).

Так, например, если испытуемому на первом этапе предъявлялись слова группы A1, то они для него были предактивированными. При этом слова группы А2 для этого испытуемого являлись альтернативными, а слова групп В1 и В2 - контрольными.

Таким образом, дизайн исследования позволяет нам сравнивать ВР на одни и те же слова, предъявленные в разных условиях разным испытуемым. Так как группы испытуемых формировались случайным образом, мы предполагали, что они являлись равноценными по когнитивным способностям. Данные по решению пространственного теста позволили нам подтвердить это предположение. Для оценки возможности случайного систематического смещения в распределении испытуемых по группам на первом этапе было проведено сравнение уровня выполнения пространственного теста. Однофакторный дисперсионный анализ не показал значимых различий между группами в количестве решенных задач в пространственном тесте $(\mathrm{F}(3,76)=0.196, p=0.899)$.

При анализе данных задачи на лексическое решение анализировалось среднее ВР на разные типы стимулов для правильных ответов. В целом точность ответов испытуемых была высока (среднее количество правильных ответов - 0.95, стд. откл. - 0.03). Из анализа были исключены данные четырех человек: средняя точность ответов трех из них была менее 0.85 , еще один испытуемый продемонстрировал экстремально высокое время реакции (более 7 сек).

Для каждого испытуемого из анализа были исключены все значения ВР, выходящие за пределы трех стандартных отклонений (среднее количество исключенных ответов составило менее 2 \%).

ВР (стд. откл.) составило: для предактивированных стимулов -776.86 мс (141.41 мс), для альтернативных стимулов - 810.23 мс (147.71 мс), для контрольных стимулов - 795.76 мс (130.54 мс).

Для проверки первой гипотезы о позитивном прайминг-эффекте по ранее предъявленным словам было проведено попарное сравнение ВР на предактивированные слова и на две другие категории слов (t-критерий Стьюдента для связанных выборок). Были обнаружены значимые различия между предактивированными и альтернативными $(t(79)=-4.89, p<0.001)$ и предактивированными и контрольными $(t(79)=-2.79, p=0.006)$ словами.

Для проверки второй гипотезы о негативном прайминг-эффекте на слова с перестановкой букв было проведено сравнение ВР на альтернативные и контрольные слова (t-критерий Стъюдента для связанных выборок). Сравнение показало, что время реакции на альтернативные слова значимо больше, чем на контрольные $(t(79)=2.21, \mathrm{df}=79, p=0.03)$. 


\section{Обсуждение}

Результаты нашего исследования показали, что использование разработанной нами процедуры, с одной стороны, позволяет зафиксировать классические эффекты позитивного прайминга повторением, а с другой демонстрирует наличие негативного прайминг-эффекта для слов с идентичным буквенным составом, но альтернативной семантикой. Альтернативные стимулы опознавались значимо медленнее по сравнению с контрольными, несмотря на то, что они не предъявлялись испытуемому на первом этапе эксперимента и испытуемый вряд ли мог подозревать, что из букв предъявленного слова можно составить другое. Эти результаты согласуются с эффектами, получаемыми в исследованиях неосознаваемого прайминга с маскировкой. С точки зрения моделей зрительного распознавания слов они означают, что семантические процессы оказываются включенными в опознание слов на ранних этапах, поэтому происходит оттормаживание стимулов, имеющих альтернативную семантику (Dunabeitia et al., 2009; Norris, 2013).

Примечательным, однако, оказывается тот факт, что ингибирующее действие ППБ-слов не ограничено миллисекундами и секундами, но может длиться минуты (среднее время решения пространственного теста составило 7 мин) и даже дни (Валуева, 2016). Так, в исследовании Е.А. Валуевой было показано, что альтернативные стимулы (спустя неделю после процедуры предактивации) обладают особым статусом при решении анаграмм. Именно в отношении альтернативных стимулов удается зафиксировать эффект инкубации, т.е. вероятность извлечения этих решений после перерыва в решении по сравнению с условием без инкубации. Получается, что эффекты, регистрируемые на микроуровне распознавания слов, являются значимыми и для макроуровня процессов мышления и решения задач в целом.

Одной из возможных теоретических интерпретаций полученных данных является теория В.М. Аллахвердова о неосознанном негативном выборе. Негативный выбор - это принятие решения о неосознании определенной информации, ее подавлении. В экспериментальных работах автора было показано, что негативно выбранная информация субъективно не эквивалентна отсутствующей и при повторном предъявлении имеет тенденцию оставаться негативно выбранной (Аллахвердов, 2006, 2015). В нашем случае это означает, что альтернативное слово, которое может быть составлено из набора букв предъявленного слова, негативно выбирается и поэтому опознается медленнее.

Данное исследование показывает возможность интеграции обособленных областей изучения когнитивных процессов, что является необходимым для полноценного понимания функционирования мышления в целом. 


\section{Литература}

Алексеева, С. В., Слюсарь, Н. А. (2017). Орфографические соседи в русском языке: база данных и эксперимент, направленный на изучение морфологической декомпозиции. Вопросы психолингвистики, 32, 12-27.

Аллахвердов, В. М. (2006). Осознание как открытие. В кн. Д. В. Ушаков (ред.), Психология творчества. Школа Я.А. Пономарева (с. 352-375). М.: Изд-во «Институт психологии РАН».

Аллахвердов, В. М. (2015). Как сознание выбирает одно значение из многих возможных. Петербургский психологический журнал, 13, 1-13.

Валуева, Е. А. (2016). Роль инкубационного периода в решении задач. Психология. Журнал Высшей школы экономики, 13(4), 789-800.

Ссылки на зарубежные источники см. в разделе References после англоязыного блока.

Приложение

Слова, использованные в эксперименте

\begin{tabular}{|c|c|c|c|}
\hline Группа A1 & Группа A2 & Группа В1 & Группа В2 \\
\hline жандарм & мандраж & горилка & рогалик \\
\hline петлица & теплица & рогатка & каторга \\
\hline заточка & зачаток & закачка & казачка \\
\hline щетина & нищета & гранат & гарант \\
\hline планка & клапан & мошкара & ромашка \\
\hline оброк & короб & кобура & уборка \\
\hline росинка & соринка & пробег & погреб \\
\hline носилки & силикон & кариес & секира \\
\hline амплуа & ампула & плеск & склеп \\
\hline зарница & разница & диктор & дротик \\
\hline коршун & шнурок & пломба & апломб \\
\hline паводок & подкова & слепень & плесень \\
\hline креатив & реактив & нектар & танкер \\
\hline петарда & адаптер & белорус & лесоруб \\
\hline мотель & отмель & тирада & триада \\
\hline санитар & старина & потеха & пехота \\
\hline стропа & пастор & барыня & рабыня \\
\hline плюшка & шлюпка & марля & маляр \\
\hline
\end{tabular}


Лаптева Надежда Михайловна - аспирант; младший научный сотрудник, Институт психологии РАН.

Сфера научных интересов: креативность, когнитивная психология, психофизиология, воплощенное познание.

Контакты: n.m.lapteva@mail.ru

Валуева Екатерина Александровна - научный сотрудник, Институт психологии РАН; ведущий научный сотрудник, Московский городской психолого-педагогический университет, кандидат психологических наук.

Сфера научных интересов: когнитивная психология, интеллект, творчество.

Контакты: ekval@list.ru

Белова Софья Сергеевна - научный сотрудник, Институт психологии РАН, кандидат психологических наук.

Сфера научных интересов: интеллект, креативность, имплицитное научение, вербальные способности, социальное познание.

Контакты: sbelova@gmail.com

\title{
Priming Effects in a Lexical Decision Task Based on Transposed-Letter Word Pairs
}

\author{
N.M. Lapteva ${ }^{a}$, E.A. Valueva ${ }^{a, b}$, S.S. Belova ${ }^{a}$ \\ ${ }^{a}$ Institute of Psychology, Russian Academy of Sciences, 13 build. 1, Yaroslavskaya Str., Moscow, 129366, \\ Russian Federation \\ ${ }^{b}$ Moscow State University of Psychology E Education, 29 Sretenka str., Moscore, 127051, Russian \\ Federation
}

\begin{abstract}
The article presents an experimental study in which the priming effects were measured in the lexical task based on transposed-letter word pairs. Thirty-six pairs of words were selected, in which one word could be transformed into another with the rearrangement of letters. At the first stage, the participants were given the task "Word pairs" which preactivated one of the two words in a pair. At the second stage, the participants had to perform spatial intelligence test. At the third stage, the participants were performing the lexical decision task in which preactivated, alternative and control words were used as stimuli. We hypothesized that the experimental effect will correspond to the results of previous experiments with unconscious priming, namely: 1) words which are identical to the primes presented before will demonstrate positive priming effect, but 2) words which consist of the same letters as primes but have different meaning will demonstrate negative priming effect. The results showed that the response time for the preactivated words was significantly lower than for alternative and control words. At the same time, the alternative words were identified slower then control words although they were not presented at the first stage, and the participants didn't know that a new word could be constructed from the letters of the presented stimulus. According to the visual word recognition models, such results could be explained by the notion that this is the semantic processes that are involved at very early stages of word recognition that cause inhibition of stimuli with alternative semantics.
\end{abstract}


However, taking into account that we have changed the classical procedure of the masked unconscious priming to delayed conscious priming, we suppose that our results demonstrate some general regularities of thinking. For instance, the established effects correspond to the data obtained in E. A. Valueva's study of the influence of incubation on solving anagrams with two answers. One of the possible theoretical interpretations of the acquired data could be the theory of unconscious negative choice developed by V. M. Allakhverdov.

Keywords: priming, rearrangement of letters, words recognition, lexical task, creativity, negative choice.

\section{References}

Alexeeva, S. V., \& Slioussar, N. A. (2017). Orthographic neighbors: A database on Russian language and experimental studies of morphological decomposition. Journal of Psycholinguistics, 32(2), 12-27. (in Russian)

Allakhverdov, V. M. (2006). Osoznanie kak otkrytie [Awareness as a discovery]. In D. V. Ushakov (Ed.), Psikhologiya tvorchestva. Shkola Ya.A. Ponomareva [Psychology of creativity. School of Ya. A. Ponomarev] (pp. 352-375). Moscow: Institute of Psychology of RAS. (in Russian)

Allakhverdov, V. M. (2015). How does consciousness choose one meaning from many? Peterburgskiy Prsikhologicheskiy Zhurnal, 13, 1-13. (in Russian)

Valueva, E. A. (2016). The role of incubation period in problem solving. Psychology. Journal of Higher School of Economics, 13(4), 789-800. (in Russian)

Andrews, S. (1996). Lexical retrieval and selection processes: Effects of transposed-letter confusability. Journal of Memory and Language, 35(6), 775-800. doi:10.1006/jmla.1996.0040

Brand, A., \& Bradley, M. T. (2012). Assessing the effects of technical variance on the statistical outcomes of web experiments measuring response times. Social Science Computer Review, 30(3), 350357. doi:10.1177/0894439311415604

Carreiras, M., Armstrong, B. C., Perea, M., \& Frost, R. (2014). The what, when, where, and how of visual word recognition. Trends in Cognitive Sciences, 18(2), 90-98. doi:10.1016/j.tics.2013.11.005

Chetverikov, A., \& Upravitelev, P. (2016). Online versus offline: The Web as a medium for response time data collection. Behavior Research Methods, 48(3), 1086-1099. doi:10.3758/s13428-015-0632-x

Dunabeitia, J. A., Perea, M., \& Carreiras, M. (2009). There is no clam with coats in the calm coast: Delimiting the transposed-letter priming effect. Quarterly Journal of Experimental Psychology, 62(10), 1930-1947. doi:10.1080/17470210802696070

Hilbig, B. E. (2016). Reaction time effects in lab- versus Web-based research: Experimental evidence. Behavior Research Methods, 48(4), 1718-1724. doi:10.3758/s13428-015-0678-9

Mousikou, P., Kinoshita, S., Wu, S., \& Norris, D. (2015). Transposed-letter priming effects in reading aloud words and nonwords. Psychonomic Bulletin and Review, 22(5), 1437-1442. doi:10.3758/s13423-015-0806-7

Norris, D. (2013). Models of visual word recognition. Trends in Cognitive Sciences, 17(10), 517-524. doi:10.1016/j.tics.2013.08.003

Perea, M., \& Lupker, S. J. (2003). Transposed-letter confusability effects in masked form priming. In S. Kinoshita \& S. J. Lupker (Eds.), Macquarie monographs in cognitive science. Masked priming: The state of the art (pp. 97-120). New York: Psychology Press. doi:10.4324/9780203502846 
Ratcliff, R., Hockley, W., \& McKoon, G. (1985). Components of activation: repetition and priming effects in lexical decision and recognition. Journal of Experimental Psychology. General, 114(4), 435-450. doi:10.1037//0096-3445.114.4.435

Scarbrough, D. L., Cortese, C., \& Scarbrough, H. S. (1977). Frequency and Repition effects in lexical Memory. Journal of Experimental Psychology. Human Perception and Performance, 3(1), 1-17. Retrieved from http://www.ncbi.nlm.nih.gov/pubmed/6457113

Schubert, T. W., Murteira, C., Collins, E. C., \& Lopes, D. (2013). ScriptingRT: A software library for collecting response latencies in online studies of cognition. PLoS ONE, 8(6), e67769. doi:10.1371/journal.pone.0067769

Semmelmann, K., \& Weigelt, S. (2017). Online psychophysics: reaction time effects in cognitive experiments. Behavior Research Methods, 49(4), 1241-1260. doi:10.3758/s13428-016-0783-4

Stoet, G. (2010). PsyToolkit: A software package for programming psychological experiments using Linux. Behavior Research Methods, 42(4), 1096-1104. doi:10.3758/BRM.42.4.1096

Stoet, G. (2017). PsyToolkit: A novel web-based method for running online questionnaires and reaction-time experiments. Teaching of Psychology, 44(1), 24-31. doi:10.1177/0098628316677643

Taft, M., \& Van Graan, F. (1998). Lack of phonological mediation in a semantic categorization task. Journal of Memory and Language, 38(2), 203-224. doi:10.1006/jmla.1997.2538

Yoon, S. Y. (2011). Revised Purdue Spatial Visualization Test: Visualization of Rotations (Revised PSVT:R) [Psychometric Instrument].

Nadezhda M. Lapteva - post-graduatte student; junior research fellow, Institute of Psychology, Russian Academy of Sciences.

Research area: creativity, cognitive psychology, psychophysiology, embodied cognition.

E-mail:n.m.lapteva@mail.ru

Ekaterina A. Valueva - research fellow, Institute of Psychology, Russian Academy of Sciences; senior research fellow, Moscow State University of Psychology \& Education, Ph.D.

Research area: cognitive psychology, intelligence, creativity.

E-mail: ekval@list.ru

Sofya S. Belova - research fellow, Institute of Psychology, Russian Academy of Sciences, Ph.D. Research area: intelligence, creativity, implicit learning, verbal abilities, social cognition.

E-mail: sbelova@gmail.com 
Правила подачи статей и подписки можно найти на сайте журнала: http://psy-journal.hse.ru

Свидетельство о регистрации средства массовой информации ПИ № ФС77-66610 от 08 августа 2016 г. зарегистрировано Федеральной службой по надзору в сфере связи, информационных технологий и массовых коммуникаций (РОСКОМНАДЗОР).

Адрес издателя и распространителя

Фактический: 117418, Москва, ул. Профсоюзная, 33, к. 4,

Издательский дом НИУ ВШЭ

Тел. $+7(495)$ 772-95-90 доб. 15298

Почтовый: 101000, Москва, ул. Мясницкая, д. 20

Тел. +7(495) 772-95-90, E-mail: id.hse@mail.ru

Формат 70x100/16. Тираж 350 экз. Печ. л. 9 